$1-1-1951$

\title{
Yellow poplar : reaction to crown release and other factors influencing growth
}

Torkel Holsoe

Follow this and additional works at: https://researchrepository.wvu.edu/ wv_agricultural_and_forestry_experiment_station_bulletins

\section{Digital Commons Citation}

Holsoe, Torkel, "Yellow poplar : reaction to crown release and other factors influencing growth" (1951). West Virginia Agricultural and Forestry Experiment Station Bulletins. 344T.

https://researchrepository.wvu.edu/wv_agricultural_and_forestry_experiment_station_bulletins/623 @ WVU. It has been accepted for inclusion in West Virginia Agricultural and Forestry Experiment Station Bulletins by an authorized administrator of The Research Repository @ WVU. For more information, please contact ian.harmon@mail.wvu.edu. 
soxir.

sives

I.

Whing.j.

Hets

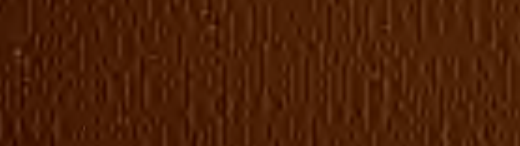

(6)

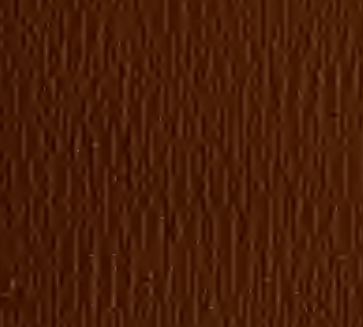

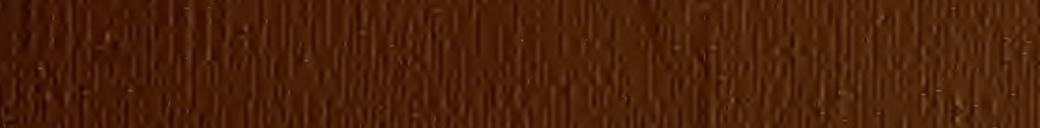
E.

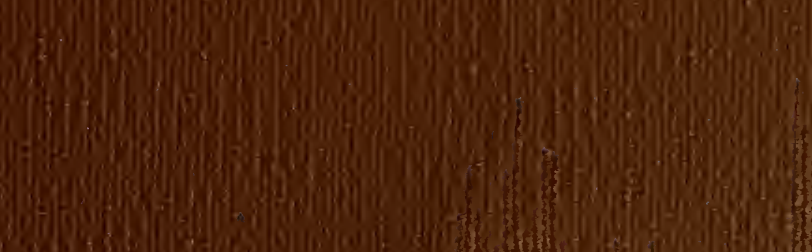

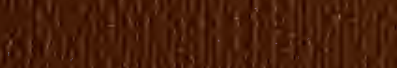

(y)

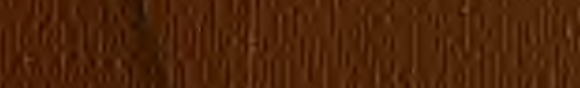

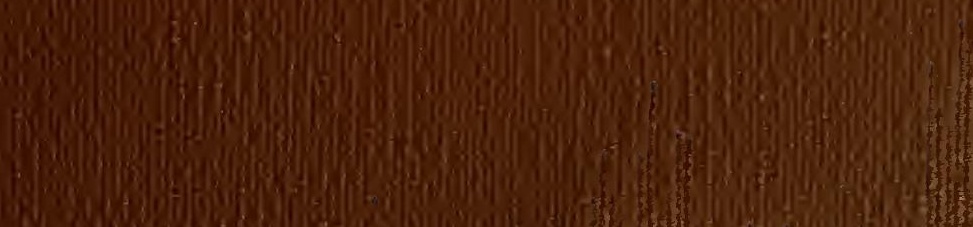


Digitized by the Internet Archive in 2010 with funding from

Lyrasis Members and Sloan Foundation

http://www.archive.org/details/yellowpoplarreac344hols 


\section{BULLETIN 344 T - JUNE 1951 \\ ?}

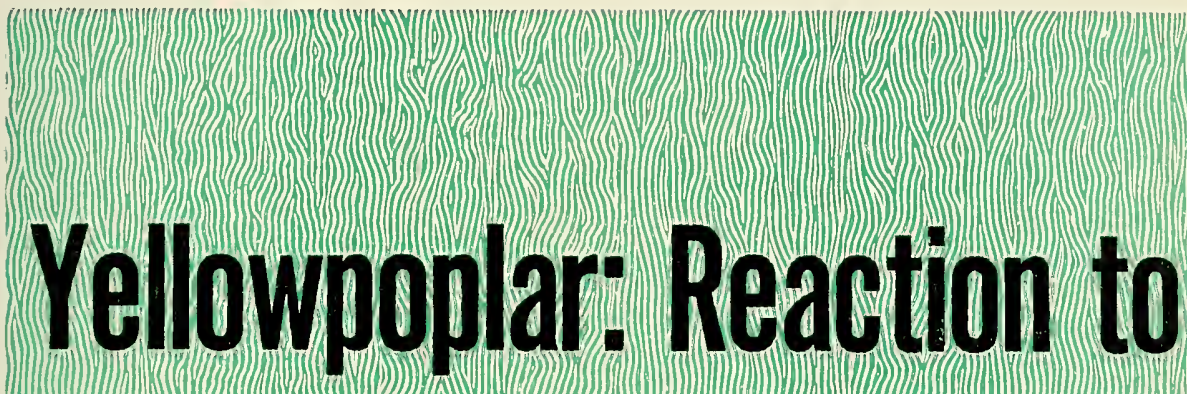

Grown Release and Other

Factors Influencing Growth

WEST VIRGINIA UNIVERSITY AGRICULTURAL EXPERIMENT STATION 



\title{
Yellowpoplar: Reaction to
}

\section{Crown Release and Other}

Factors Influencing Growth

\author{
By Torkel Holsoe
}


TORKEL HOLSOE, author of Yellowpoplar: Reaction to Crown Release and Other Factors Influencing Growth, is a Forester at the West Virginia University Agricultural Experiment Station and Professor of Silviculture in the College of Agriculture, Forestry, and Home Economics.

\author{
West Virginia University \\ Agricultural Experiment Station \\ College of Agriculture, Forestry, and Home Economics \\ H. R. VARney, DiRector \\ MORGANTOWN
}




\section{Contents}

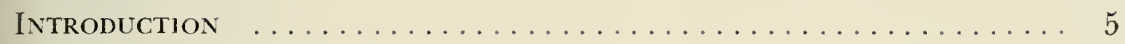

PURPOSE of EXPERIMENT $\ldots \ldots \ldots \ldots \ldots \ldots \ldots \ldots \ldots \ldots \ldots$

Earlier Studies and Related Investigations $\ldots \ldots \ldots \ldots \ldots \ldots .7$

ESTABLISHMENT OF EXPERIMENT $\ldots \ldots \ldots \ldots \ldots \ldots \ldots \ldots \ldots \ldots$

PROCEDURE

A. Measurements of Sample Trees .................. 19

B. Determination of the Time at Which Light and Shade Leaves

Are Formed ......................... 15

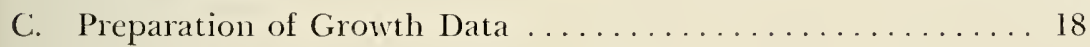

Observations Made During the Experiment

A. Differences in Radial Growth on the Individual Trees During

First Week of the Growing Season .............. 2 ?

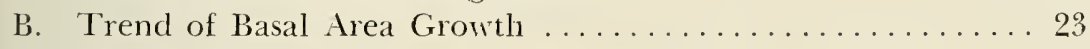

C. Influence of Precipitation on Weekly Basal Area Growth . . . 26 Reslets ani Discussion

A. Crown Release Classifications .................. 28

P. Crown Release During the Dormant Season . . . . . . . . . . 29

(. Crown Release During the Growing Season ............ 30

D. Reaction to Crown Release During Dormant Season of Trees of Different Crown Classes ...............

E. Reaction to Crown Release During Growing Season of Trees of Different Crown Classes ................. 13

F. Reaction of Different Crown Classes to the Same Percentage of Crown Release .......................... 52

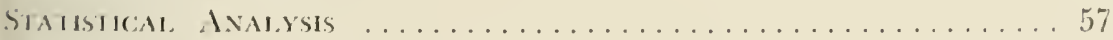

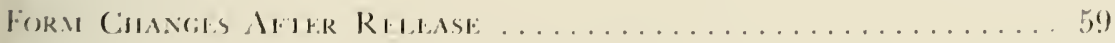

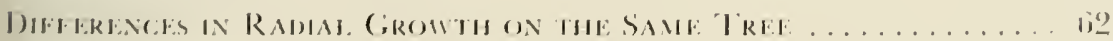

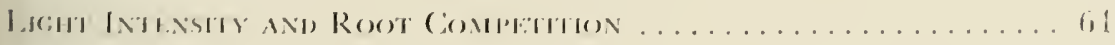

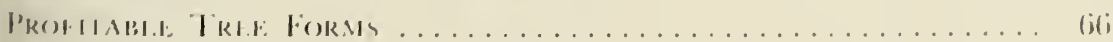

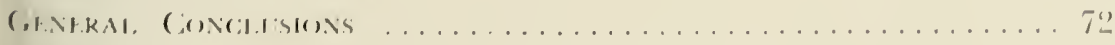

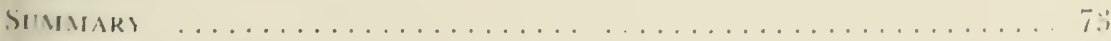

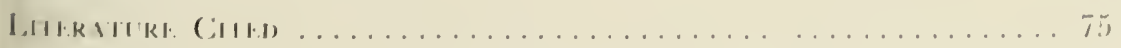

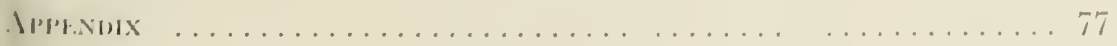





\section{Introduction}

In the past most research in silviculture and forest management has dealt with the growth of stands composed of various forest tree species on different sites. Through permanent sample plots we have obtained a more or less complete knowledge of the growth of stands, their rate of production, and the amount of products that can be harvested from them at rotation age. Complete information has been furnished by Moller (21) who has constructed tables for four to six site indices for beech (Fagus silvatica L.), oak (Quercus robur L.), and Norway Spruce (Picea abies Karst.) in Denmark. These give for average Danish thinnings the relationship between age and total height, current annual growth, average annual cut, basal area, volume diameter breast high (d.b.h.), and number of trees per hectare. These tables give a complete guide for management of stands after site index has been determined.

In this country some sample plots have been established in different forest cover types giving the current annual growth of various species. Since no standard treatments of the stands have been determined, such as have been developed through more than a hundred years of management in the European forests, these sample plots have not given any accurate directives for treatment of the stands to obtain different dimensions in certain lengths of time.

Although it may be possible in pure stands to give rather specific directions about volume to be removed and frequency of thinnings, such as has been done in Europe, this still does not indicate to the forester which tree he should select for cutting and which tree he should leave. Although guides are extremely helpful in predicting the developnent of the entire stand, they do not hetp the forester in his choice of trees when marking for thimning. In this comtry where many of the stands are mixtures of up to ten or filteen valuable species, an intimate knowledge of mot only the individual species but also of the individual tree is necessary. Belore making the rhoice of rutling or leaving a tree, the forester should know what will happen if he does one or the other. He should know what the reaction will be on the tree that is left if he cuts onc, two, or three trees that ane interlering with its cromon development. Most research in silviculume and forest man-

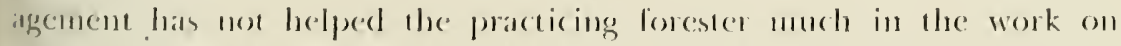
which he spends a great deal of his time-mancly, developing, horough some form of cutting, the individual trees that form the forest stands.

The first step in this direction came more than a humeledel years

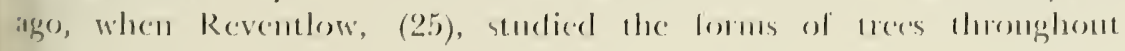


their different stages of development. Reventlow indicated that European beech should grow up in partial shade and in fairly dense stands whereby it would develop a certain amount of clear length. After this had been obtained, the tree should be given space for continued crown expansion. This would develop a deep and rounded crown and maintain a relatively fast diameter growth. These thoughts, however, were forgotten during the following years when the German influence in silviculture and forest management was governing. The thoughts during that time were almost entirely focused on entire stands and the production per area unit. The individual tree was forgotten.

Not until Biolley (1) showed interest in the uneven-aged and mixed stands managed under the selection system did the development of the individual tree come to the forefront. Later foresters such as Mundt (10) in Denmark expanded on the work of Biolley and applied the selection system. This helped re-establish interest in the individual tree instead of more or less pure stands of beech. Later studies by Heck (11), Busse (5), and Macon (18), without too much success tried to relate various crown dimensions with diameter growth. The interest in the growth of the individual tree, however, had been awakened.

In recent studies on red oak (Quercus borealis Michx.) and white ash (Fraxinus americana L.) in New England (13), and yellowpoplar (Liviodendron tulipifera L.) in West Virginia (14), it was found that a highly significant relationship existed between basal area growth and various crown dimensions such as crown diameter, crown length, and crown surface. It also was shown for yellowpoplar (14) that at an age of 100 years, using the arbitrary value of 100 for the first 16 -foot $\log$, the second $\log$ has a value of 59.5 , whereas the third $\log$ is worth only 42.5 compared to the value of the first $\operatorname{lgg}$. Therefore, it was recommended that as soon as the first two 16-foot logs were included in the dead length, it would be advantageous to maintain as much live crown on the trees as possible to encourage fast diameter growth.

In line with these recommendations, the question arises, What will be the reaction on trees that have been released in various degrees? Since it has been established that the basal area growth is closely related to the size of the crown, it will be of interest to know if light releases will have different effects on the trees than more or less complete release. If the latter is possible, it would be feasible, by heavy thinnings, to create good growing conditions lor the remaining trees through a profitable operation and thereby make thinnings in more or less inaccessible areas that have been neglected because thinning operations, according to conventional methods, could not be made at a profit because of the small volume removed in each cutting. 


\section{Purpose of Experiment}

Since the amount of material removed in each thinning is closely related to the economics of such an operation, and since the forester marking for thinning is constantly confronted with the question of how much crop trees should be released, this experiment was established to study the reaction of various degrees of release on individual, remaining trees.

By releasing the crowns of clominant, codominant, and intermediate trees in various degrees at times both before and during the growing season, it was hoped to furnish practicing foresiers with answers that would help them in their timber management work. In this country, where cuttings take place throughout the year, it may be expected that released trees might react differently, depending on the season in which the release occurs. To investigate this, it was decided to release some of the sample trees during the dormant season and others during the growing season. It may be expected that if the crown of a tree receives a more or less complete release during the growing season, many of the shade leaves on the lower part of the crown or in other shaded places might be damaged by the sudden increase in light intensity and thereby cause a reduction in growth. Because of this, it was decided to investigate the cell structure from week to week during the beginning of the growing season. The summer release was not to be made until the cell structure of the leaves had become fixed.

\section{Earlier Studies and Related Investigations}

Most European foresters have advocated that thimnings should be light and made lrequently since, otherwise, the remaining trees will receive a shock that will retard their growth lor some years. Although this theory has been employed as a standard operating procedure in lingopean lorestry, it does not seem to have been based on investigations. Few references in the litcrature can be lommel relating to this shock (flfert alter beavy thinnings. Juncker (16) stated that "it is important (1) make the shock of liberation as small as pessible on the standing arees so that they will fill in the space immediately." In other cases where the slesek reaction has been mentioned, special relerence hats been male to panticular soil types. For cxample lonrnchusch (9) stated that "too sudken and severe release in forest stands, particularly on heavy and moist clay soils, may have damaging eflect which will show up as drying ont of the upper crown. In such casces the heavy dhinning will cause the lecight groweth to slow "1p." This same phenomenon 
has been observed in this country by Jensen and MacAloney (15). They stated that "during the second growing season after about half of the volume of a yellow birch and paper birch stand was removed, decadence became evident in the tops of yellow birch. Water sprouts were noted on almost half the yellow birch in the treated area. . . In spite of indications of decadence following logging, a cutting of this type stimulated the growth rate of residual yellow birch over the 15-year period following cutting. . . At the end of the 15-year period, the water sprouts along the lower part of the bole had disappeared and those near the original crown had developed into a part of the new crown."

In contrast to this, Wadsworth (27) described the reaction of suppressed and intermediate ponderosa pine (Pinus ponderosa Laws.) that received complete release from competition. He stated that "the effect of release upon diameter growth was pronounced." The trees that were released completely grew an average of 2.2 inches on diameter breast high during the ten years following release, compared to 6 inches during the decade before release.

Through recent work on red oak and white ash in New England (13) and yellowpoplar in West Virginia (14), determinations were made on the effect of different crown dimensions on basal area growth. These studies also have shown the development from sapling to mature size of the individual tree that will produce the greatest amount of clear wood outside the knotty core in the most economical way. The measurements were taken on trees of different sizes. This indicates that such development is possible if the trees are given adequate space. In order to obtain accurate results, however, it will be necessary to measure the development of the individual tree and its reaction to different amounts of crown release rather than to make comparisons between different trees. Such studies have not been made, probably because it would be necessary to have very accurate measuring devices or to wait for several years before measurements could be taken with conventional instruments.

Through the introduction of micrometer measurements of radial growth, as brought out by Reineke (24), Daubenmire (7), and Brown, Rose, and Spurr (4), it is now possible to measure radial growth of trees with an accuracy of .001 inch. A micro-dendrometer has been fashioned by attaching a micrometer permanently to a block of hard. wood to which also is fastened a metal plate with a glass covering. The metal plate is framed along part of the edge with a metal shield. A standard dial gauge micrometer, manufactured by the B. C. Ames Company of Waltham, Massachusetts, or by L. S. Starrett Company: 
Athol, Massachusetts, is used. The spindle of the micrometer is placed perpendicularly to the glass plate. On the trees to be investigated, three round-headed brass screws about three inches long are screwed through the bark into the wood, so that they are well anchored in the rood. The position of the screws is such that the line between the upper two is horizontal. The distance between these two screws is a little less than the width of the glass plate of the micro-dendrometer. All screws are placed perpendicularly to the surface of the tree so they will form continuations of radii. The third screw is between the upper two screws and approximately three inches below the line between them. The micro-dendrometer is placed so that the upper screws rest on the glass plate against the frame shielding the upper edge of the glass plate, and in such a way that one of the upper screws hits the corner of the shield. The spindle will then touch the bark in the same place each time measurements are taken. This can be seen in Figures 1, 2, and 3. On this particular place, the bark is smoothed down, and a small glass plate $3 / 4$ by $3 / 4$ inch is glued to the bark. The screws will keep their position because the tree will grow out over them, but the glass plate will change its position relative to the heads of the screrrs, for it will move with the bark. Therefore, by means of the

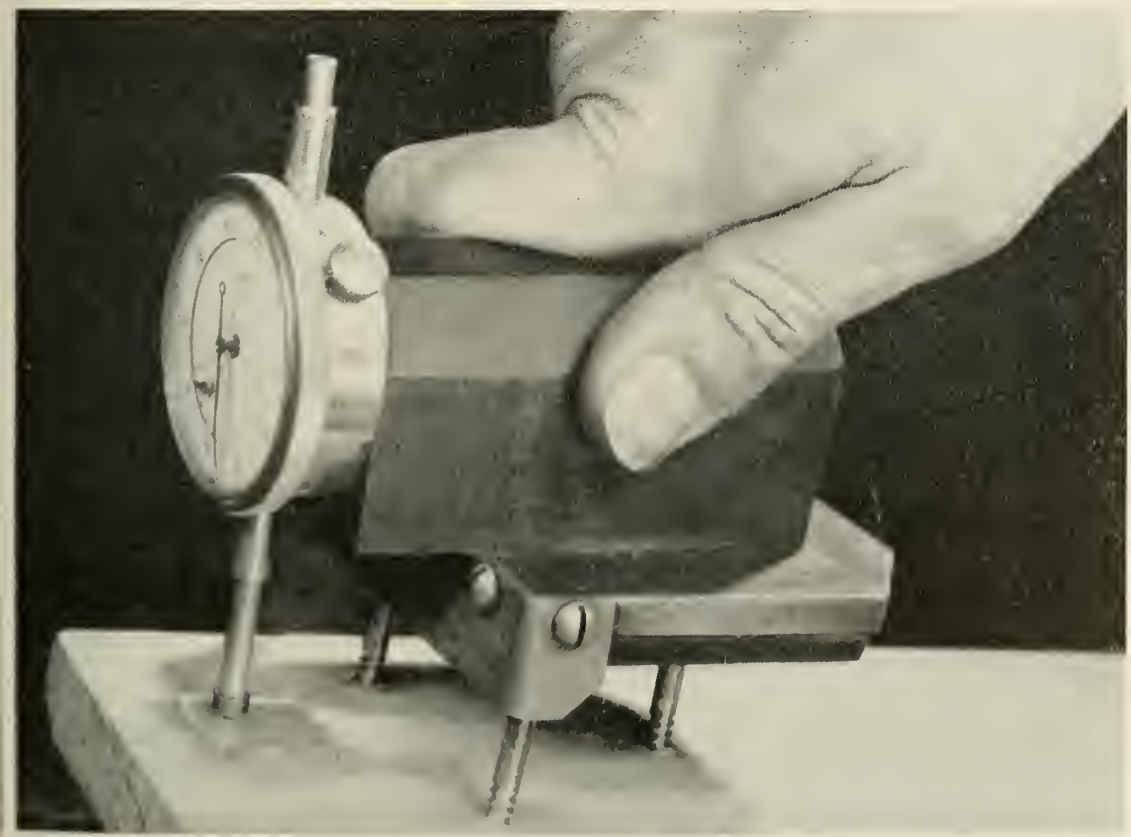

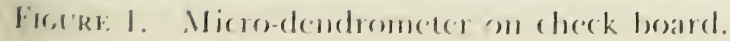




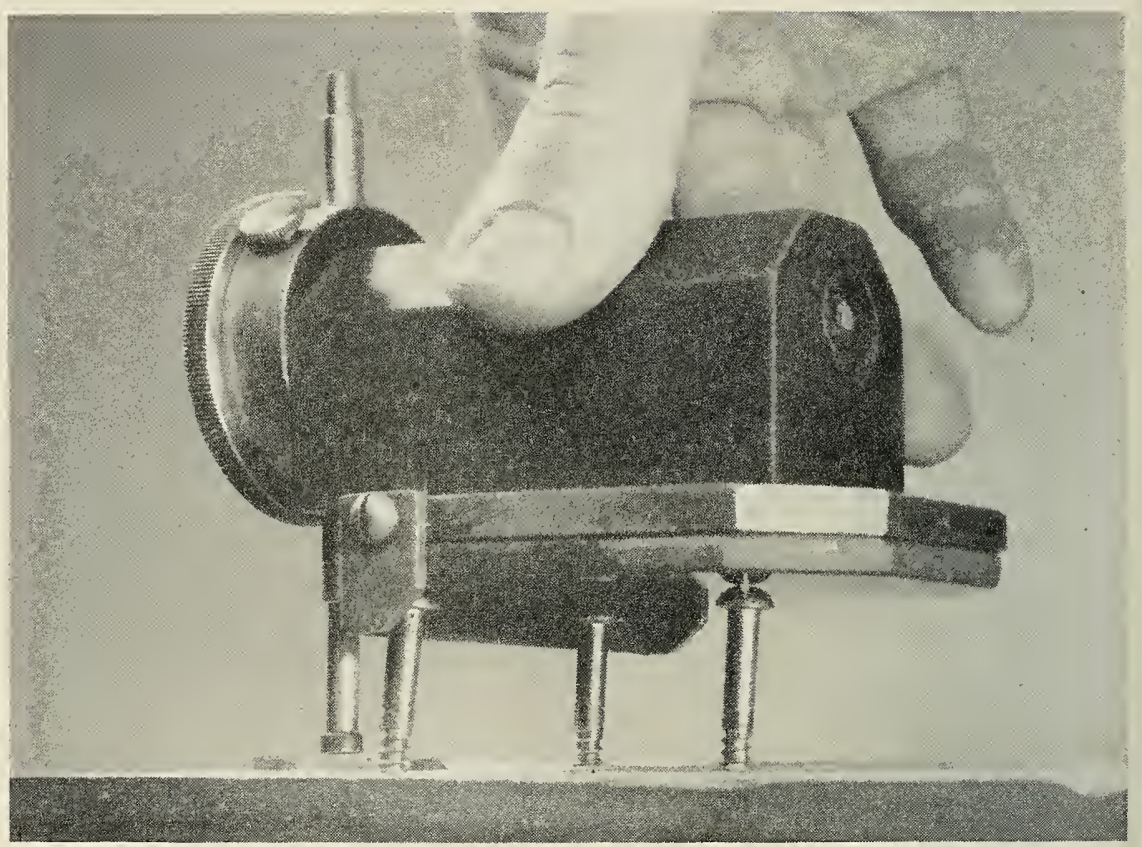

Figure 2. Micro-dendrometer on check board.

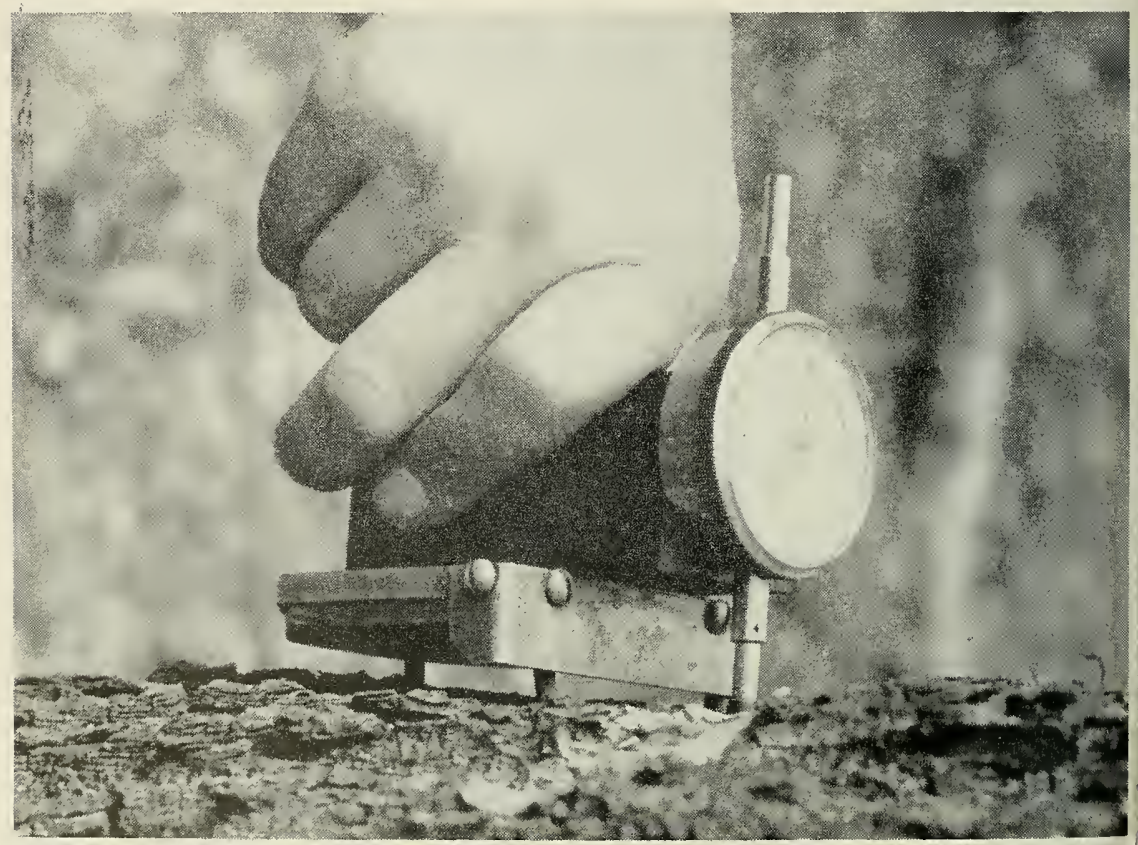

FIGURE 3. Micro-dendrometer on tree station. 
micro-dendrometer it is possible to measure the difference in position between the glass plate and the heads of the screws.

Since only one instrument is necessary to take numerous measurements, and since it is possible to have as many stations on the individual tree as the diameter will allow, this instrument is extremely important in silvicultural research. Measurements can be made rapidly with an accuracy of .001 inch. In the present experiment, with one man taking the measurements and one man recording, it was possible to average I50 measurements per hour.

Stephens and Spurr (26) used a micro-dendrometer to investigate the daily growth before and after crown release in red pine (Pinus resinosa Sol.). They found that an increased rate of growth could be observed within twenty-four hours after the trees were releasecl. By measuring trees on which dendrometer stations were established both morning and evening, these investigators found the daily variation in the radial dimensions of trees. The radial growth curve has a sawtoothed shape, since the trees expand at night but contract during the day. The difference between the expansion and the contraction constitutes the daily growth. In that experiment, however, no measurements were taken regarding the extent to which the remaining trees were released.

\section{Establishment of Experiment}

The experimental area used was situated on a farm woods owned by West Virginia University. The area, about forty acres, is approximatcly two miles north of Morgantown, West Virginia, on latitude 39 degrees 40 minutes north, and longitude 79 degrees 56 minutes west. The forest cover type is gencrally yellowpoplar-white oak-red oak (10). The yellowpoplar is predominating in many places.

Yellowpoplar was chosen for this investigation because this species is fairly incolerant, and therefore is rather scusitive 10 sudden changes in lighe intensity. Furthermore, yellowpoplar is one of the most important timber speries in the Appalachian region. Large areas of alumest pure stands of even-aged yellowpoplan of high density ance found throughoun the Appalachian region. These stands are in great need of thimning, even to the extent that many have completely stagnated. Since many of them ane situated in mather inacessible places, however, they cammot be thimed profitably cumless a considerable volume is removed in carch cutcing.

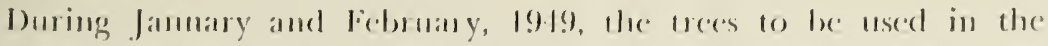
experiment were selected. They ranged in diancede loreast high liom 
6.4 inches to 26.1 inches. To investigate the influence of release on as wide a range of conditions as possible, intermediate, codominant, and dominant trees were selected. The trees were numbered. A letter was assigned to each tree to indicate whether it was to be a control tree or to be released. A total of 193 trees was selected for the experiment, and 51 were designated as controls. Of the 193 trees, 50 were of the dominant crown class, whereas 119 were codominant, and 24 were intermediate. The composition of the stand made it impossible to include more intermediate trees in the experiment.

Dendrometer stations were established on all the trees to be used in the experiment. On each of the control trees, stations were placed in such a way that they faced the cardinal compass directions. On the first control tree the station faced north, the second east, third south, fourth west. On the trees to be released there were established from two to five stations. These were placed so that if the tree were to be released fron one side by the removal of a neighboring tree, a station was placed facing this tree and another one was placed on the diametrically opposite side. If the tree was to be released by the removal of several surrounding trees, stations were placed so that they laced all released sides. In addition, one station was placed on a neutral side.

The dendrometer stations were established, as earlier described. in conformity with the findings of Brown, Rose, and Spurr (4). The micro-dendrometer used in this experiment varied from the one mentioned by these research workers in that the wooden block that holds the micrometer was extended about an inch. Thus the spindle was removed the same distance from the metal shield. This was done so that the spindle could be placed farther away from the screws and thereby prevent possible callus formation around the screws from influencing the measurements. By trial it was found that a rubber compound cement was the best lasting glue to keep the glass plates on the trees in position during the entire growing season. The glass plates, on which the spindle of the micrometer rests, were placed $41 / 2$ feet above the ground representing measuring height. At the same time, the diameter breast high of the sample trees was measured with a diameter tape to the nearest tenth of an inch.

No thinnings or cuttings had been made during the eight previous years in the vicinity of the sample trees at the time the experiment was started, and no release of the sample trees was made during the 1949 growing season. Therefore, the growth factors would be somewhat similar to what they had been during the years previous to the establishment of the experiment. 


\section{Procedure}

\section{A. Measurements of Sample Trees}

The measurements of radial growth of the yellowpoplar trees were first taken on April 30, 1949, when the buds started to swell and some bud scales had begun to open. The measurements were taken each Saturday morning between 8:30 and 11 o'clock. The trees were examined in the same sequence so that each dendrometer station was measured at about the same time of day. Each morning before the microdendrometer was used, the reading was checked against a station established on a well-dried board kept in the office. At the end ot each series of measurements, the micro-dendrometer was again checked to see if any changes had occurred in the adjustment of the instrument. The measurements of each station were recorded with an accuracy of five ten-thousandths of an inch on a prepared sheet, as shown in Figure 4. By the end of September no more growth was recorded on any of the dendrometer stations. The measurements were discontinued until the following spring.

During the winter of 1949-50, all of the dendrometer stations used for the previous summer's work were examined. In some instances callus formation had developed around the screws. Since it was feared that this formation might continue during the following growing season, and thereby influence the growth uncler the glass plate, it was dcemed advisable to move the stations. To compensate for any error, every other station was moved up six inches and the others were moved down six inches. Later analyses showed that this movement of stations had no significance in recording radial growth. At the end of the experiment it also was found that the fear of the callus formation influencing the growth under the glass plate was not justified. By the end of the second growing season it was noticed that the callus from the screw holes did not extend more than one-hall inch out from these. Since the glass plate never was closer than one and one-half inches (o) any of the screws, the callus formation could not have influenced the position of the glass plate.

Compredensive measurenents of atl the 193 sample trees were taken during the dommant seasom. Total height, dear lenghth, and dead length were measmed to the nearest loot with and Abney level. Clear length was defined as the heighe from the ground to the first dead bameh, whereas deat length was determined as the height from the groumel on the first live branch. Corown length was measured liem

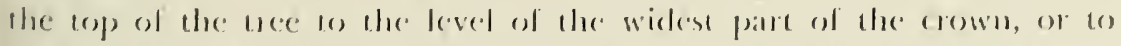
the branch eipes of the lowese live branches. Il the coown was imegular, 


$$
\text { Date: April 30,1949. Time: 9:07-12:55 Weather: Sunny-dry }
$$

\begin{tabular}{|c|c|c|c|c|c|c|c|c|c|c|c|c|c|}
\hline & & & & & & & & & & & & & \\
\hline 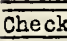 & & 4.2 & & 51.6 & & 72.2 & 1590 & 93.6 & 820 & $18 . \mathrm{c}$ & 60 & .44 & \\
\hline & 180 & $24 . b$ & 45 & 2.2 & 5630 & 2.6 & 5220 & $93 . c$ & 8900 & 118.0 & $\partial x$ & 145. & \\
\hline & & 25.2 & & 52.6 & 5720 & & .5540 & $93 . d$ & 0 & & 1110 & & \\
\hline & & $25 . b$ & & 53.2 & & 3.6 & 5530 & 94.2 & & (.2) & & 40 & \\
\hline & .4635 & $26 . a$ & 275 & 53.5 & $x$ & 74.2 & 5250 & 34.6 & 5460 & 120.6 & .5155 & 146. & 5690 \\
\hline & .4635 & 26.6 & 110 & $53 . c$ & 25 & 4.5 & .5800 & 95.2 & 500 & & .5505 & & \\
\hline है & .6390 & 27.2 & 20 & $53 . d$ & 60 & $74 . c$ & & 95.6 & 035 & 121.6 & .5010 & 147. & \\
\hline & .5520 & $27 . b$ & 00 & 54.2 & 4195 & 74.0 & 5380 & 96.2 & 130 & $22 . a$ & .5930 & 148.0 & 5 \\
\hline & 4650 & $28 . a$ & & 54.6 & $\infty$ & 5.2 & 880 & 96.6 & 6610 & 22.7 & & 148 & \\
\hline & 4235 & 28.6 & & 55.2 & & 75.6 & 5565 & $97 . a$ & 1950 & 123 & 6340 & 148. & \\
\hline & 6490 & 29.0 & 90 & 55.6 & 24 & $76 . a$ & .70 & 73 & 5140 & 124 & 5795 & 148.0 & .7170 \\
\hline & 5930 & 29.6 & 35 & $55 . c$ & & 6.5 & & 98.2 & 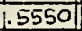 & 125.2 & & 149 & $=-1$ \\
\hline$a$ & 6230 & 30.2 & 151 & 55.2 & 5400 & $77 . \mathrm{a}$ & 500 & 98.5 & 5320 & 25.6 & .4930 & 150 & 53 \\
\hline & & $30 . \mathrm{b}$ & & $55 . e$ & & 7.6 & & 50 & & 5 & & 2 & \\
\hline 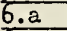 & 5435 & 31.2 & & 5.2 & -1 & $78 . a$ & & 100.2 & .5290 & 127.2 & 4640 & 152 & 52 \\
\hline & .5190 & 31.0 & 30 & 56.5 & 30 & 78.6 & 35 & 50.6 & 541 & 27.6 & .5660 & 153.2 & 60 \\
\hline 2 & .5155 & 32 & 550 & 57.2 & 10 & $78 . \mathrm{c}$ & & 51 & .490 & 28.0 & & 5 & $\underline{2}$ \\
\hline & 717 & 33.2 & 680 & 57.6 & & $78 . d$ & & 102.2 & .4510 & 128.6 & .5745 & 154.2 & \\
\hline & .6 & 33.6 & & 58 & & & & 102.6 & 6350 & 129 & .5250 & 154.6 & 38 \\
\hline. $\mathrm{b}$ & 0 & 34.2 & & 59.2 & & 0 & & 103 & & 130.2 & & 155 & \\
\hline & 585 & 34.6 & 5 & 59.6 & & 81.2 & .5 & 104.0 & 5800 & 130.0 & .5170 & 156.0 & \\
\hline & 5645 & 35.2 & 70 & $59 . c$ & & .0 & & 4.6 & & & & & \\
\hline & .5280 & 35.6 & 120 &.$d$ & & . a & & $5 . a$ & 770 & 130.0 & .5430 & 56 & \\
\hline & 4 & 36 & & $9 . e$ & & b & 2 & 6 & 4365 & 31.2 & 615 & & \\
\hline & 4040 & 37 & & 60.2 & & $83 . a$ & - & $5 . c$ & & 131.6 & .5800 & - & \\
\hline & & 38.2 & $\infty$ &.$b$ & & & & $5 . d$ & & 32.2 & .5530 & & 52 \\
\hline & 4060 & 38.6 & 80 & & & & & & & & W & .0 & 45 \\
\hline & .4910 & 39 & 260 &.$b$ & 440 & 83.0 & 560 & $107 . a$ & .3475 & 133.2 & .5565 & 157.0 & 49 \\
\hline & 5310 & 40 & 50 & & & & & & & 133.6 & 4150 & 158.2 & .38 \\
\hline & 4 & & & & & & & & & 7I & 35 & & 50 \\
\hline.$d$ & 6550 & & 440 & 3.2 & .5 &.$a$ & 0 & & 1.49 & 135 & 750 & 115 & 50 \\
\hline & & & & $3 . b$ & & & & & & 36.2 & .5265 & & \\
\hline & 5425 & 44 & & & & & & & & 36.6 & .5980 & & \\
\hline & & 5.2 & & & & 86.6 & & & .481 & $137 . a$ & .6075 & $160 . \mathrm{b}$ & 50 \\
\hline & & & & & & & & & & & & & .67 \\
\hline & & & & & & & & & & 138 & .220 & & \\
\hline & &.$b$ & & .6 & & .2 & 5895 & & .5030 & 39 & 4245 & 161.0 & 61 \\
\hline & .4 & & & & 56 & & & & & 14 & .4400 & & \\
\hline & &. $\bar{d}$ & & $3 . b$ & & a & & .6 & & $140 . \mathrm{b}$ & .6485 & & \\
\hline & & & &.$a$ & 4 & b & .54 & & 48 & $141 . a$ & .5000 & & \\
\hline & & & & & & & & & & & .4890 & & \\
\hline & 95 &. $\mathrm{a}$ & & 70.0 & & 90.6 & & 15.2 & & & & 163.0 & \\
\hline & .4755 & .6 & $4=$ & 70.6 & & & & 5.6 & .5 & & .5200 & & \\
\hline & & .2 & & & & & & & & & 489 & & \\
\hline b & 425 & 49.6 & & $70 . \bar{d}$ & & 7.. & & & 5 & $142 . d$ & 4790 & & \\
\hline & & 50 & & -2 & & 92.6 & & 110 & 5135 & 143 & & & \\
\hline 78 & & 5 & & & & & & 118.6 & & & & & \\
\hline
\end{tabular}

Figure 4. Field recording sheet for weekly measurements.

an average value was determined. Diameter breast high was measured to a tenth of an inch with a diameter tape. To calculate the average crown diameter, the crown projection was mapped. This was done by placing a plane table inside the crown projection. An alidade was fashioned from an engineer's scale to which a small metal piece with 
an eye at the zero point was attached. This scale was fastened to the plane table. It was used to sight along, and at the same time offset, the measured dimensions. A steel tape was fastened on the ground exactly below the zero point of the alidade. By following the outline of the crown ancl calling off the distances, it was possible to draw in the crown projection directly on the plane table. Besides projecting the crown of the sample tree, all neighboring tree crowns touching or interfering with the crown of the sample tree were projected and drawn in on the sketch. This can be seen in Figure 5. With an Abney level the heights of interference of all neighboring crowns were recorded. By converting the area of the crown projection to a circle with the same area, the average crown cliameter was determined.

By means of the formula for the surface of a paraboloid:

$$
A=\frac{\pi r}{6 h^{2}}\left(4 h^{2}+r^{2}\right) 3 / 2-r^{3}
$$

where $r$ is equal to half the crown diameter and $h$ is equal to the crown length, the surface of the crown was calculated.

The surface of interference was determined by the formula for the parabola:

$$
A=2 / 3 a b
$$

where $a$ was the height of interference and $b$ was the projected extent of interference between the two crowns.

According to the outline of the project, it was planned to release hall of the sample trees, except the 51 control trecs, during the domant scason. The other half were to be released during the growing season. The plan also called for releasing the trees according to the circumference of the crown by quarters. From the crown projection of the sample trees and their neighbor trees, it was determined in the office which trees should be cut in order to give them the prescribed amome of release. The cutting for the release was completed cluring March, 1950 .

The measurements were stanted on $\lambda_{\text {prit }} 29$, 1950, when the buds stirted to break.

The second release took place during the third and lourth weeks in fune, or cluring the eighth week of the growing scason.

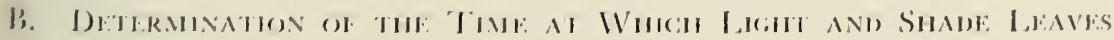
ARF FOR.MI:D

As soon as the leaves epened afler the growing season statted. leates forme expeosed and shady pesilions were collented. Slickes were 


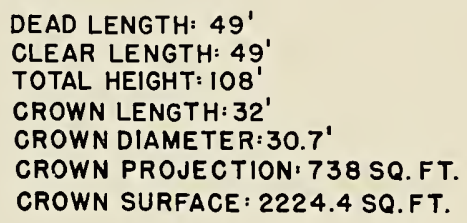

TREE NO. 112 (DOMINANT)

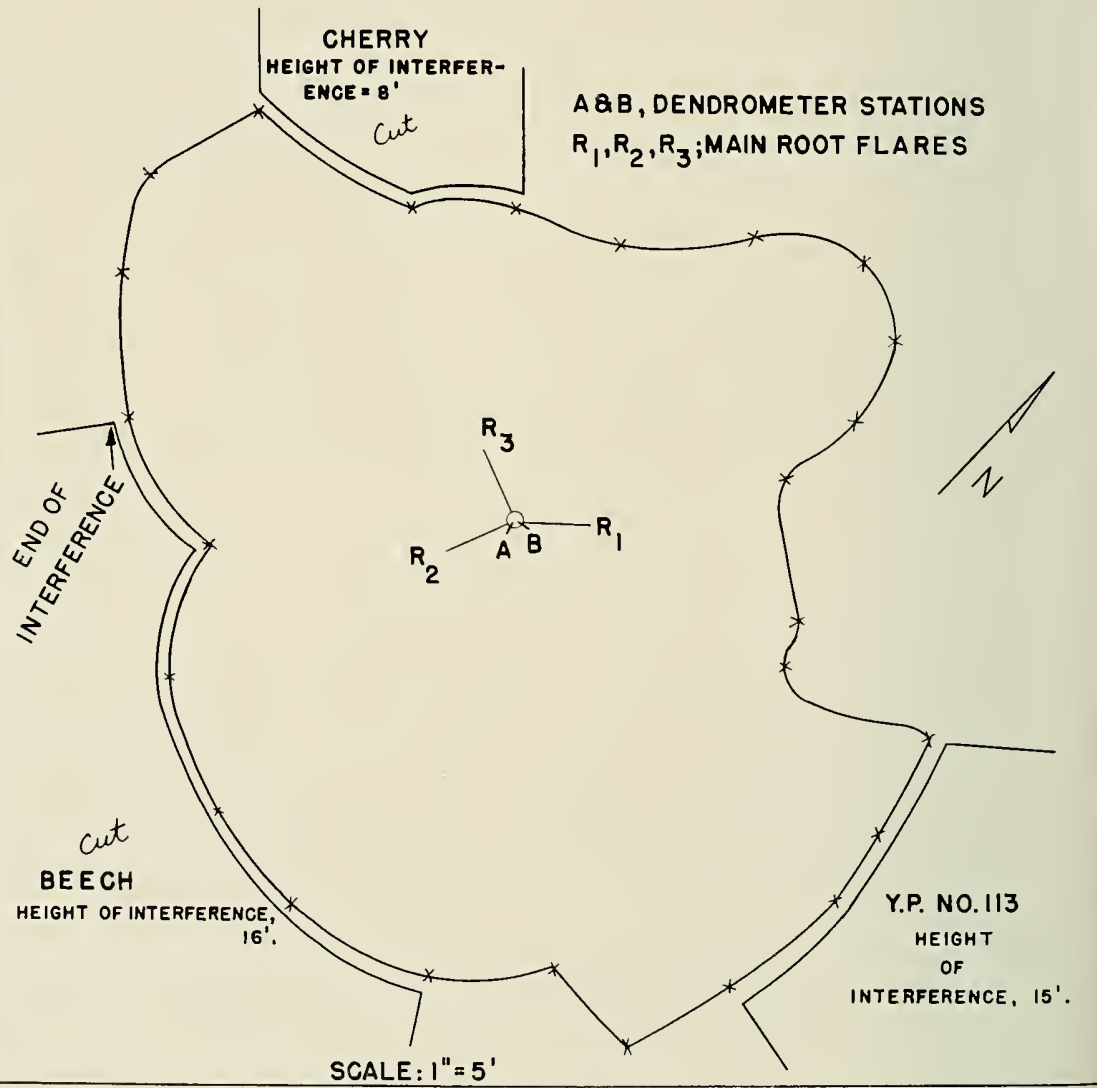

Figure 5. Projections of crowns of sample tree and neighboring trees.

prepared from these leaves to determine the development of the cells, particularly the palisade cells. During the first week in May the cell structure of light and shade leaves was the same. The first indication of a difference between the two kinds of leaves showed up in the latter part of May, or during the third and fourth weeks after the growing season started. It can be assumed that during the first weeks the cell construction is about the same on all the leaves, since the leaf 
cover is still light and, therefore, will not create too much shade on the lower placed leaves. Later, when the shade on the lower leaves becomes denser, the differentiation between light and shade leaves takes place. During the fourth week of the growing season, palisade cells appeared on the light leaves. In the beginning only one layer of palisade cells was present, but at the beginning of June, or after the leaves had been out for about five weeks, a second layer of palisade cells showed up. By the middle of June no further change in the cell structure took place on either the light or the shade trees. To be sure that no more change took place in cell structure in the leaves, the release of the rest of the trees was delayed until the latter part of June, or after the seventh week of the growing season had been completed.

In conjunction with the release of trees, the question arises as to when the foundation of the leaf structure is determined. This has been mentioned by research workers in plant physiologly. Eames and MacDaniels (8) stated that "the number of palisade layers and the density of the cell structure depends largely, either directly or indirectly, upon the light intensity." Clements (6) suggested that "palisade cells are usually converted into sponge cells in the shade and sponge cells into palisade cells in the sun." Furthermore, Clements stated that "sun species transferred to the shade usually change much or all of their palisade tissue into sponge." The foregoing authors do not state if the cell structure of the leaves is already determined in the bud formed the previous growing season, or if the change takes place after the new leaves come out. This question is brought out by Müller (23) who stated on page 212 (translated from Danish): "As far as trees and bushes are concerned, the formation of shade and light leaves depends on the light intensity to which the branch is exposed during the year the bud is formed."

Since this question would be of importance in explaining any shosk reaction of the trees doring the first year of growth affer a heavy release, it was decided to investigate this matter further. During the 1949 growing scason a gromp of ycllowpoplar reproduction (abour four lece high) was focaled. The trees in this groulp grew in dense shade. This had caused their lecight grewth to be redirded so that the average was atome four to five inclese. leal samples were eollected from these trees, and examination showed that all the leaves had only spenge rells and no palisade cells. Doring the winter of 1949-50, four of these trees were transplanted lo ant open anca in the vicinity with the same general expesure and site. Leaves were colfecterl dorting the

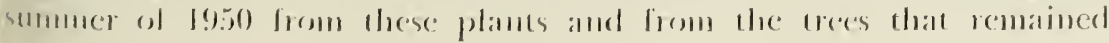


in the shade on the same area from which the first plants had been taken. Figures 6 and 7 show the cell structure of these leaves. It is evident that no palisade cells are present in Figure 6, which shows a typical leaf from the trees that remained in the shade. Figure 7 shows a typical leaf from the trees transplanted from the shade during the winter into an open space. All leaves collected from these transplanted trees showed the same cell structure. Therefore, it seems that the leaf structure is not determined by the "light intensity to which the branch is exposed during the year the bud is formed" as stated by Müller (23), but is determined by the light intensity under which the new leaf opens during the first seven weeks of the growing season.

\section{Preparation of Growth Data}

As soon as the growth data from the dendrometer stations were obtained from the field, these figures were transferred to the forms shown in Figures 8, 9, and 10. Under "Corrected Measurements" were placed the readings obtained with the micro-dendrometer after they were corrected for the differences that occurred while checking the instrument before using it on each day of measurement. The figure listed above this column is a new base figure that was used after July 15 when an adjustment was made on the instrument. The next two columns are self-explanatory. These three columns were filled out for each measuring station on each tree. On tree No. 112, the crown projection of which is shown, there were two stations. The accumulated diameter growth was averaged and used in Figure 10, which gives the data for the tree. On the basis of diameter breast high measurement that was made before the growing season started, the diameter dimension for each week of the growing season was recorded. These measurements were made to .01 inch. Basal area tables to .01 inch (Appendix) were constructed. From these the basal area was found. The last column gives the accumulated basal area growth in square feet.

Basal area growth is used in all discussions about growth, since it was found (13) that this unit has a closer relationship to crown development than does straight diameter growth. Figure 11 shows the relationship between crown surface in square feet and basal area growth for 1949 in square feet for 193 yellowpoplar trees. The correlation index for this curve is .966 , which is considered highly significant. This checks very well with the relationship found in an earlier study for red oak and white ash (13), in which the relationship between crown surface and last ten years basal growth was used. 


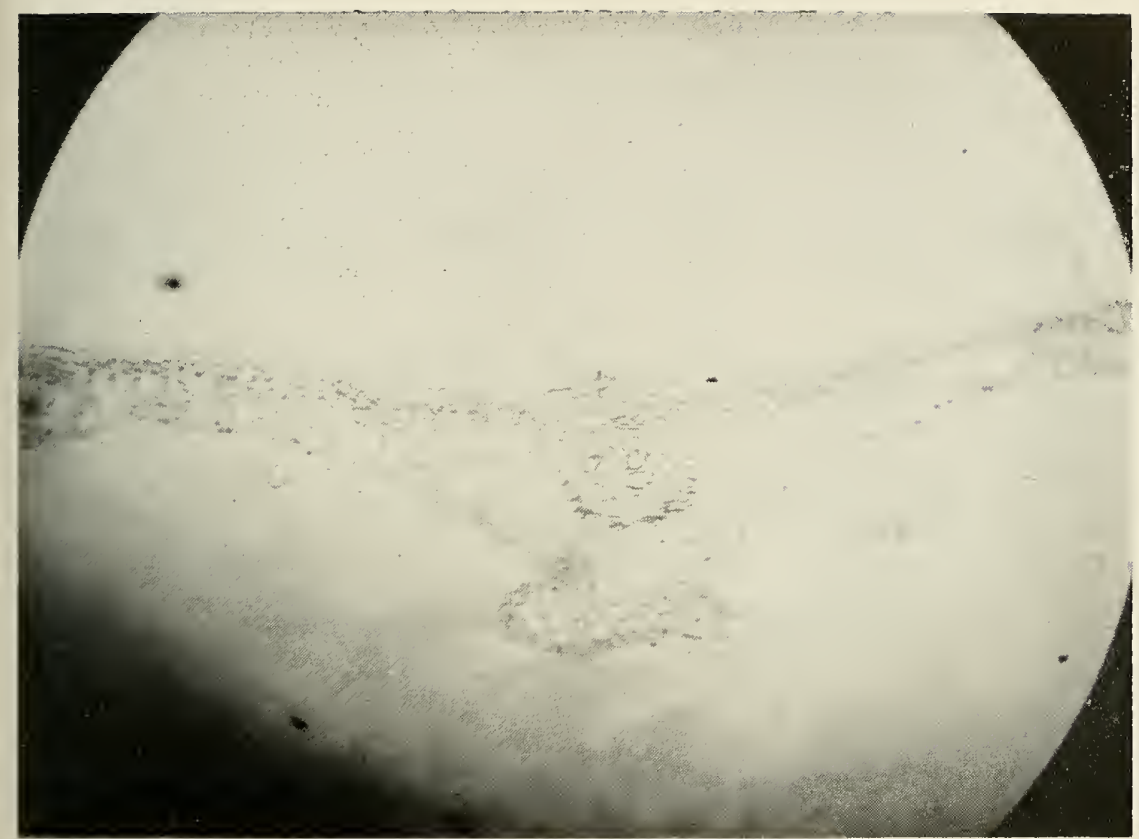

Figure 6. Microscopic cross section of shade leaf.

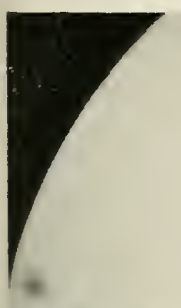

$$
\text { b }
$$

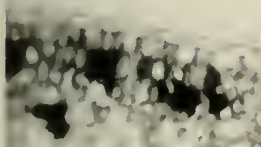

,
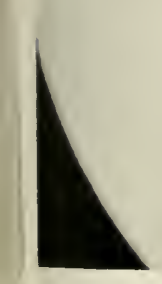

IHeivre. 7. Microsconpic crons section of lightu leal. 
Tree Number 112 Species YallowpoplarD.B.H. Oct.150

Total Height

Crown Diem.

Station:

A

Nay 150

Dee.d Lensth

Clear Length

New base figure

to be used below line: .5460 4/29/50 Check Meas:

\begin{tabular}{|c|c|c|c|c|c|}
\hline Dates & $\begin{array}{l}\text { Corrected } \\
\text { lieasureveris }\end{array}$ & $\begin{array}{l}\text { Accumulictive } \\
\text { Redial Crowth }\end{array}$ & $\begin{array}{l}\text { Accumulative } \\
\text { Dian. Crovth }\end{array}$ & $\begin{array}{c}\text { Diam. } \\
\text { Dimension }\end{array}$ & $\begin{array}{r}\text { Basal } \\
\text { frea }\end{array}$ \\
\hline $4 / 23 / 50$ & .5340 & - & - & & \\
\hline $5 / 6 / 50$ & .5360 & .0020 & .0040 & & \\
\hline $5 / 13 / 50$ & .5380 & .0040 & .0080 & & \\
\hline $5 / 20 / 50$ & .5430 & .0090 & .0180 & & \\
\hline $5 / 27 / 50$ & .5515 & .0175 & .0350 & & \\
\hline $6 / 3 / 50$ & 5670 & .0330 & .0660 & & \\
\hline $6 / 10 / 50$ & .5825 & .0485 & .0970 & & \\
\hline $6 / 17 / 50$ & .6000 & .0660 & .1320 & & \\
\hline $6 / 24 / 50$ & .6180 & .0840 & .1680 & & \\
\hline $7 / 1 / 50$ & .6250 & .0910 & .1820 & & \\
\hline $2 / 8 / 50$ & .6590 & .1250 & .2500 & & \\
\hline $2 / 15 / 50$ & .6825 & .1485 & .2970 & & \\
\hline $7 / 22 / 50$ & .7180 & .1720 & .3440 & & \\
\hline $7 / 29 / 50$ & .7240 & .1780 & .3560 & & \\
\hline $8 / 5 / 50$ & .7690 & .2230 & .4460 & & \\
\hline $8 / 12 / 50$ & .7890 & .2430 & .4860 & & \\
\hline $8 / 19 / 50$ & .8045 & .2585 & .5170 & & \\
\hline $8 / 20150$ & .8150 & .2690 & .5380 & & \\
\hline $2 / 2 / 50$ & .8270 & .2810 & .5620 & & \\
\hline $2 / 9 / 50$ & .8290 & .2830 & .5660 & & \\
\hline $9 / 15 / 50$ & .8350 & .2890 & .5780 & & \\
\hline $9 / 23 / 50$ & .8360 & .2900 & .5800 & & \\
\hline
\end{tabular}

Figure 8. Calculation sheet for individual station (Tree No. 112, Station A). 
Tree ivumber 112 Species YallowpoplarD.B.H. Oct. 150 Na.y 150 Station: $B$ Diam. Growth

New base figure

to be used below line: $.50604 / 29 / 50$ Check liex:
Oc'.. :49

Total Height

Crown Diem.

Dee.d Length

Clear Length

\begin{tabular}{|c|c|c|c|c|c|}
\hline Dite: & $\begin{array}{l}\text { Corrected } \\
\text { Yiezure:uentis }\end{array}$ & $\begin{array}{l}\text { Accumulitive } \\
\text { Rediel onoth }\end{array}$ & $\begin{array}{l}\text { Accumliative } \\
\text { Dieñl. Crovth }\end{array}$ & $\begin{array}{c}\text { Diam. } \\
\text { Dimension }\end{array}$ & $\begin{array}{r}\text { Basal } \\
\text { Lrea }\end{array}$ \\
\hline $4 / 29 / 50$ & .4940 & - & - & & \\
\hline $5 / 6 / 50$ & .5020 & .0080 & .0160 & & \\
\hline $5 / 13 / 50$ & .5055 & .0115 & .0230 & & \\
\hline $5 / 20 / 50$ & .5120 & .0180 & .0360 & & \\
\hline $5 / 27 / 50$ & .5260 & .0320 & .0640 & & \\
\hline $6 / 3 / 50$ & .5390 & .0450 & .0900 & & \\
\hline $6 / 10 / 50$ & .5770 & .0830 & .1660 & & \\
\hline $6 / 17 / 50$ & .6000 & .1060 & .2120 & & \\
\hline $6 / 34 / 50$ & .6150 & .1210 & .2420 & & \\
\hline $7 / 1 / 50$ & .6420 & .1480 & 2960 & & \\
\hline $2 / 3 / 50$ & .6710 & .1770 & .3540 & & \\
\hline $2 / 15 / 50$ & .6970 & .2030 & .4060 & & \\
\hline $2 / 22 / 50$ & .7400 & .2340 & .4680 & & \\
\hline $2 / 29 / 50$ & .7680 & .2620 & .5240 & & \\
\hline $8 / 5 / 50$ & .7970 & .2910 & .5820 & & \\
\hline $8 / 12 / 50$ & .8205 & .3145 & .6290 & & \\
\hline $8 / 19 / 50$ & .8410 & .3350 & .6700 & & \\
\hline $8 / 20 / 50$ & .8450 & .3390 & .6780 & & \\
\hline $3 / 2 / 50$ & .8700 & .3640 & .7280 & & \\
\hline $2 / 2 / 50$ & .8730 & .3670 & .7340 & & \\
\hline $2 / 10 / 50$ & .8800 & .3740 & .7480 & & \\
\hline $3 / 23 / 50$ & .8830 & .3770 & .7540 & & \\
\hline
\end{tabular}

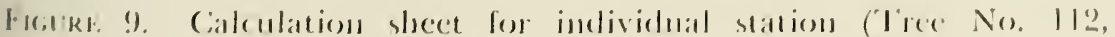
Station B). 


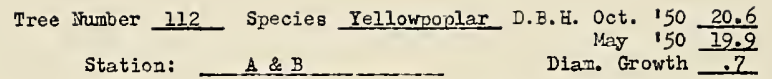

\begin{tabular}{|c|c|c|c|c|c|c|}
\hline Dates & $\begin{array}{c}\text { Corrected } \\
\text { Measurernents } \\
\end{array}$ & $\begin{array}{l}\text { Accurnolative } \\
\text { Radial Growth }\end{array}$ & $\begin{array}{l}\text { Accumulative } \\
\text { Diam. Growth } \\
\end{array}$ & $\begin{array}{c}\text { Diam. } \\
\text { Dimension }\end{array}$ & $\begin{array}{l}\text { Basal } \\
\text { Area } \\
\text { sq. Tt }\end{array}$ & $\begin{array}{l}\text { Accumulative } \\
\text { Basal Area Growth }\end{array}$ \\
\hline $4 / 29 / 50$ & & & $-\infty$ & 19.90 & 2.1598 & .0000 \\
\hline $5 / 6 / 50$ & & & .0100 & 19.91 & 2.1620 & .0022 \\
\hline $5 / 13 / 50$ & & & .0155 & 19.92 & 2.1642 & .0044 \\
\hline $5 / 20 / 50$ & & & .0270 & 19.93 & 2.1668 & .0070 \\
\hline $5 / 27 / 50$ & & & .0495 & 19.95 & 2.1707 & .0109 \\
\hline $6 / 3 / 50$ & & & .0780 & 19.98 & 2.1772 & .0174 \\
\hline $6 / 10 / 50$ & & & .1220 & 20.02 & 2.1860 & .0262 \\
\hline $6 / 17 / 50$ & & & .1720 & 20.07 & 2.1969 & .0371 \\
\hline $6 / 24 / 50$ & & & .2050 & 20.10 & 2.2035 & .0437 \\
\hline $7 / 1 / 50$ & & & .2390 & 20.14 & 2.2123 & .0525 \\
\hline $7 / 8 / 50$ & & & .3020 & 20.20 & 2.2255 & .0657 \\
\hline $7 / 15 / 50$ & & & .3516 & 20.25 & 2.2365 & .0767 \\
\hline $7 / 22 / 50$ & & & .4060 & 20.31 & 2.2498 & .0900 \\
\hline $7 / 29 / 50$ & & & .4400 & 20.34 & 2.2564 & .0966 \\
\hline $8 / 5 / 50$ & & & .5140 & 20.41 & 2.2770 & .1172 \\
\hline $8 / 12 / 50$ & & & .5545 & 20.45 & 2.2809 & .1211 \\
\hline $8 / 19 / 50$ & & & .5935 & 20.49 & 2.2898 & .1300 \\
\hline $8 / 26 / 50$ & & & .6080 & 20.51 & 2.2943 & .1345 \\
\hline $9 / 2 / 50$ & & & .6450 & 20.55 & 2.3032 & .1434 \\
\hline $9 / 9 / 50$ & & & .6500 & 20.55 & 2.3032 & .1434 \\
\hline $9 / 16 / 50$ & & & .6630 & 20.56 & 2.3055 & .1457 \\
\hline $9 / 23 / 50$ & & & .6670 & 20.57 & 2.3077 & .1479 \\
\hline
\end{tabular}

Figure 10. Calculation sheet for average values of all stations.

\section{Observations Made During the Experiment}

A. Differences in Radial Grotvth on the Individual Trees During First WeEk of The Growing Season

On May 7, 1949, when the measurements at the end of the first week of the growing season were taken, it was noted that some of the trees showed no growth on one station, whereas another station on the same tree would have grown as much as .0025 inch.

Measurements from 18 trees, each of which had four dendrometer stations placed in the cardinal compass directions, showed the following 


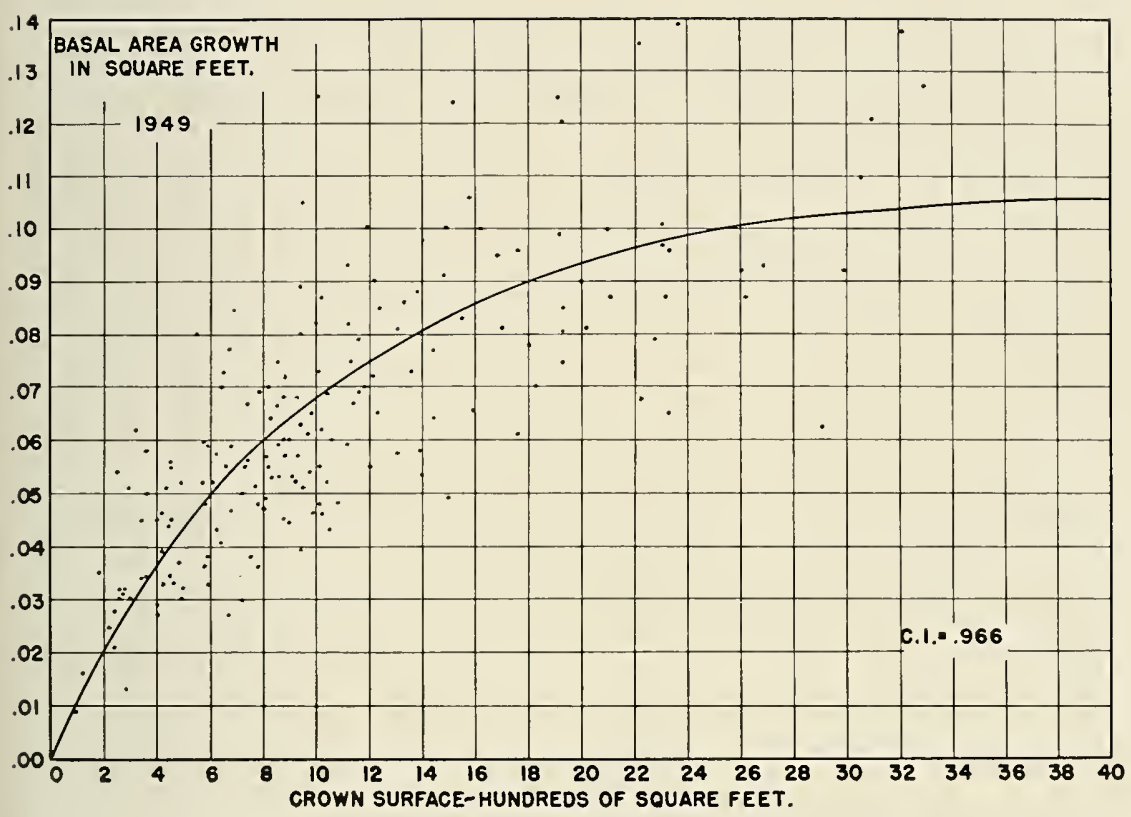

Figure 11. Relationship between crown surface and basal area growth for 193 trees.

average growth in inches by the end of the first week of the growing season:

$\begin{array}{lrcr}\text { North } & \text { South } & \text { East } & \text { West } \\ .00219 & .00325 & .00228 & .00247\end{array}$

From these mcasurements it can be seen that the south side of the trees grew considerably laster than any other side. After the south sicle in rate of growth comes the west side, and then the east and north sides. This seems logical, because the south side will be warmest, atter which the west side will receive more heat than the east or the north sides.

\section{l). Trenid of Basal Area Growtil}

The maxinum growth of basal area hegins at the end of the sixth weck of the growing season, or about func lo, as caln be sech in Figures 12 and 1\%. This maximum growth ontinues motil about the thirtecnth weck, or July 29. On some trees growth is completely stopped by the fiftecenth weck, or August 12, but other trees will contimuc to grow unt dee nincteenth week, or Scptember 9. The end of radial growth at

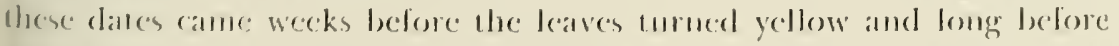
any critical temperatures occomred during the night. This did not happen until bate October. This occurrence has becen investigated by 


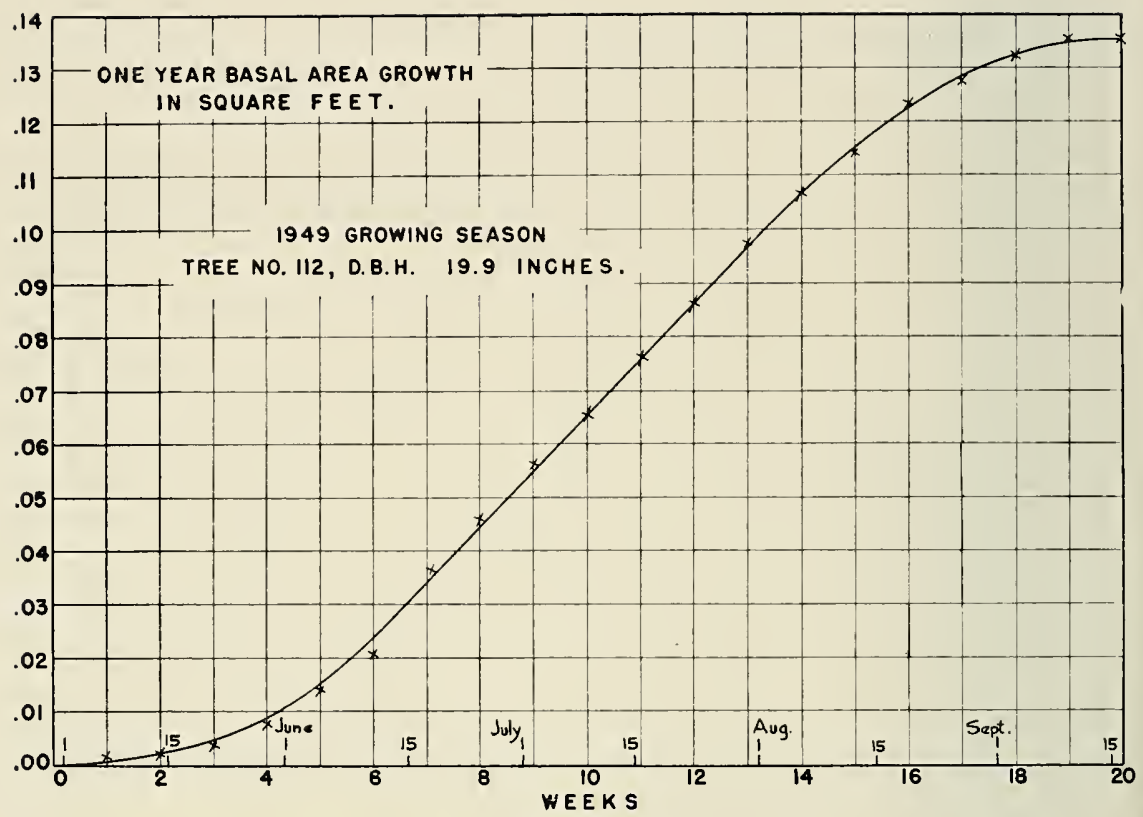

Figure 12. Basal area growth during 1949 season for Tree No. 112.

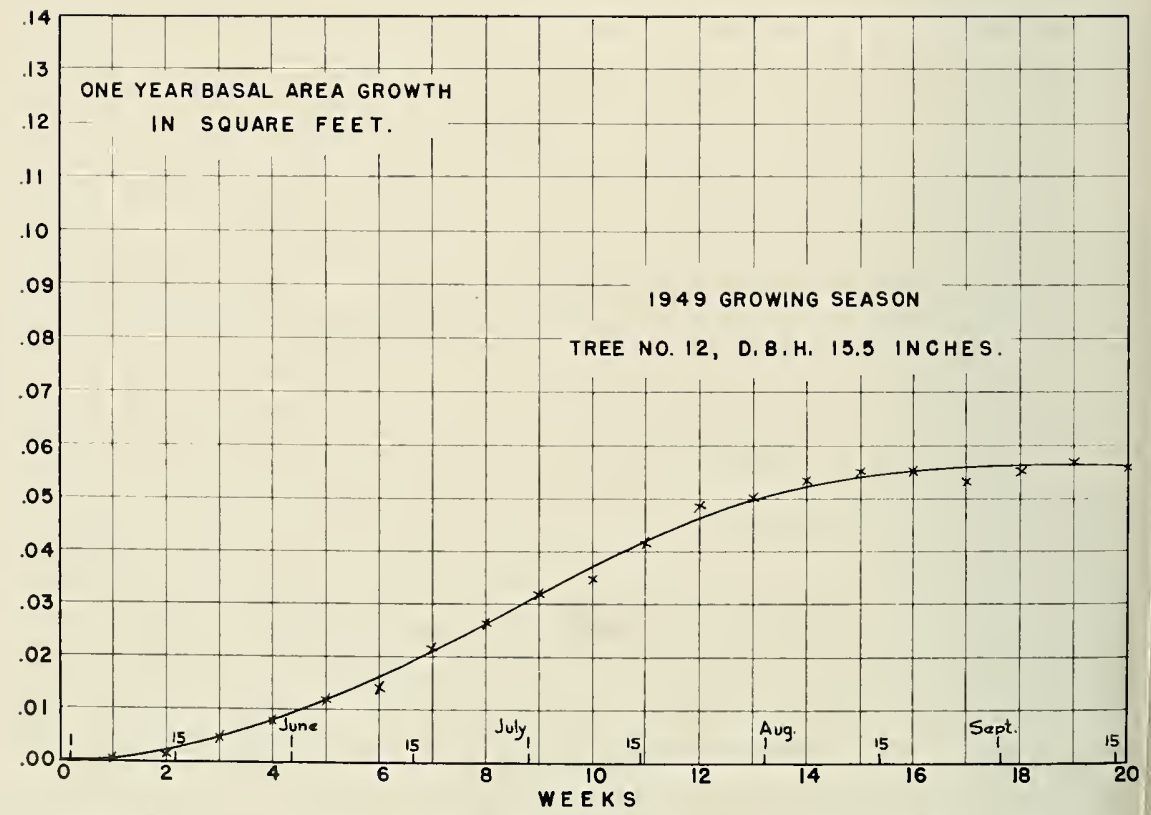

FIGURE 13. Basal area growth during 1949 season for Tree No. 12 
Kramer (17). He finds that "for certain species the time at which dormancy begins and ends is closely related to the length of the day. The shortening days of late summer may bring about the cessation of growth in some of the more sensitive species considerably before it would be stopped by decreasing temperature." Kramer also points out that "among species investigated were yellowpoplar which would grow continuously in greenhouse if supplied continuous light. If no additional light was supplied, the growth would stop at the same time inside and outside greenhouse."

In order to investigate this further, the weekly basal area growth for all the sample trees was examined. There were 186 trees since seven trees were excluded from the experiment because they had been damaged when a new road was constructed. The trees were divided into three groups: (1) trees that were released during the winter between the two growing seasons investigated, (2) trees that were released during the last week in June, 1950, and (3) the control trees. Figure 14 shows the weekly growth of these three classifications. It is evident that the growth already falls off after the thirteenth week, or about July 29. A pronounced reduction in growth takes place on August 12, or at the end of the fifteenth week. This culmination of growth occurs in all

WEEKLY BASAL AREA GROWTH

IN TEN THOUSANDTHS OF I SQUARE FOOT.

1950

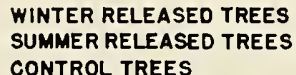

CONTROL TREES

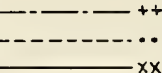

70

80

.

to

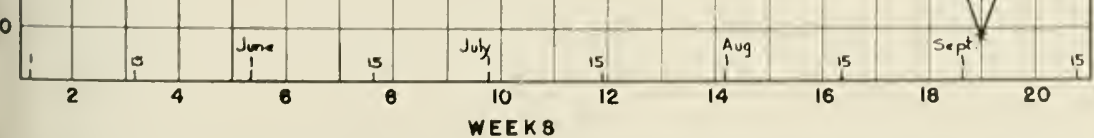

Fratk1. 14. Weekly basal ancal gromell ol winter-releascel, summorrefeascel, and comblol trees doring l!)50. 
three groups of trees at about the same time, although the released trees, even in this period of declining basal area growth, will produce more growth.

\section{Influence of Precipitation on Weekly Basal Area Grotvth}

A comparison of the curve for basal area growth of 51 control trees during the 1950 growing season with the growth during 1949 (Figure 14), showed that the average value for each week's growth generally was higher during 1950. Since the 1950 growing season was wetter than the 1949 growing season, it was considered of interest to investigate how precipitation during each week of the growing season would influence the basal area growth. Figures 15 and 16 show the current average weekly growth of basal area of 51 control trees during the 1949 and 1950 growing seasons. These figures also show the weekly precipitations for the same period. Although the two curves show some similarity, the tendency seems to be that the effect of precipitation often does not register on the growth until the following week. The delay in reaction is particularly apparent when the heavy precipitation occurred a day or two before the micro-dendrometer measurements were taken. In such cases, the beneficial effect of the precipitation was carried over into the following week.

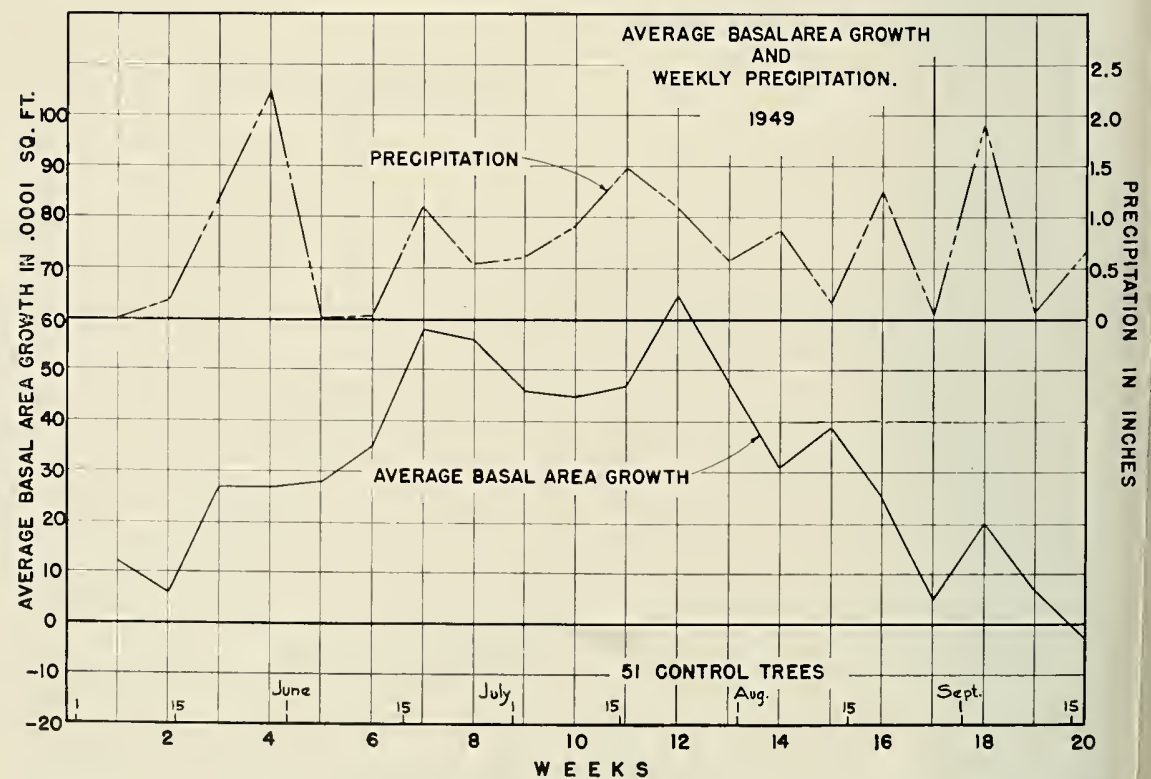

Figure 15. Current average weekly basal growth of 51 control trees related to weekly precipitation during 1949 . 


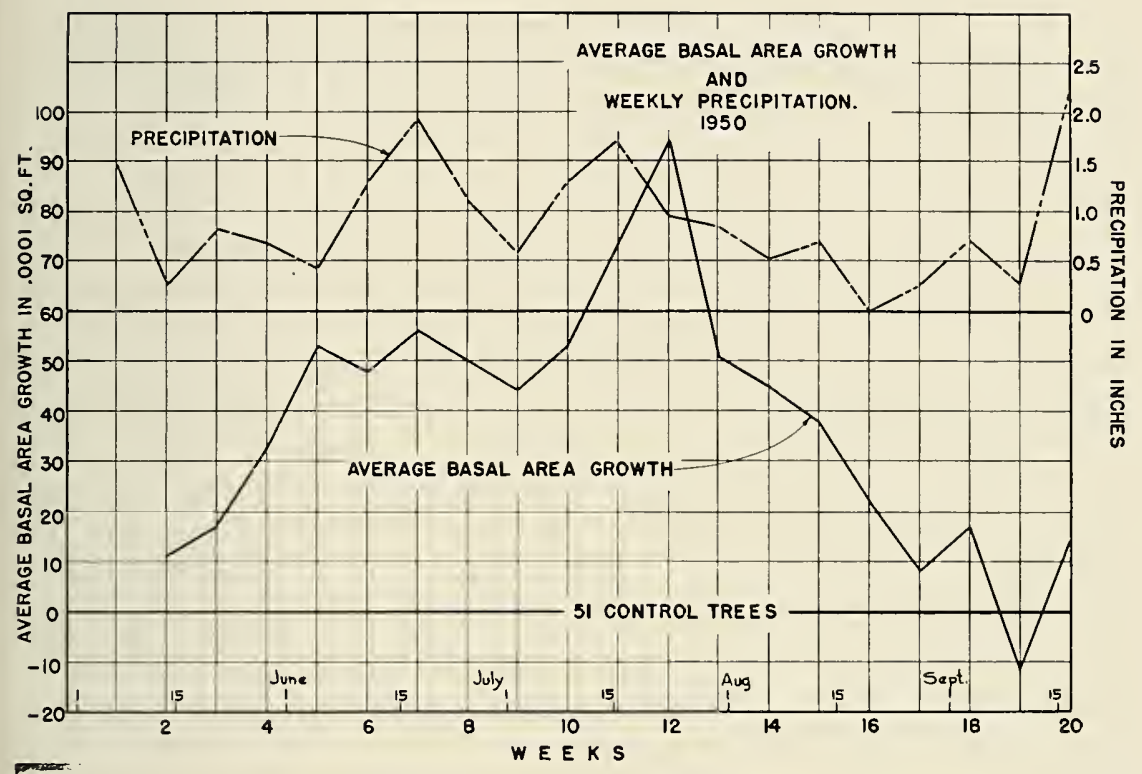

Figure 16. Current weekly basal area growth of 51 control trees related to weekly precipitation during 1950.

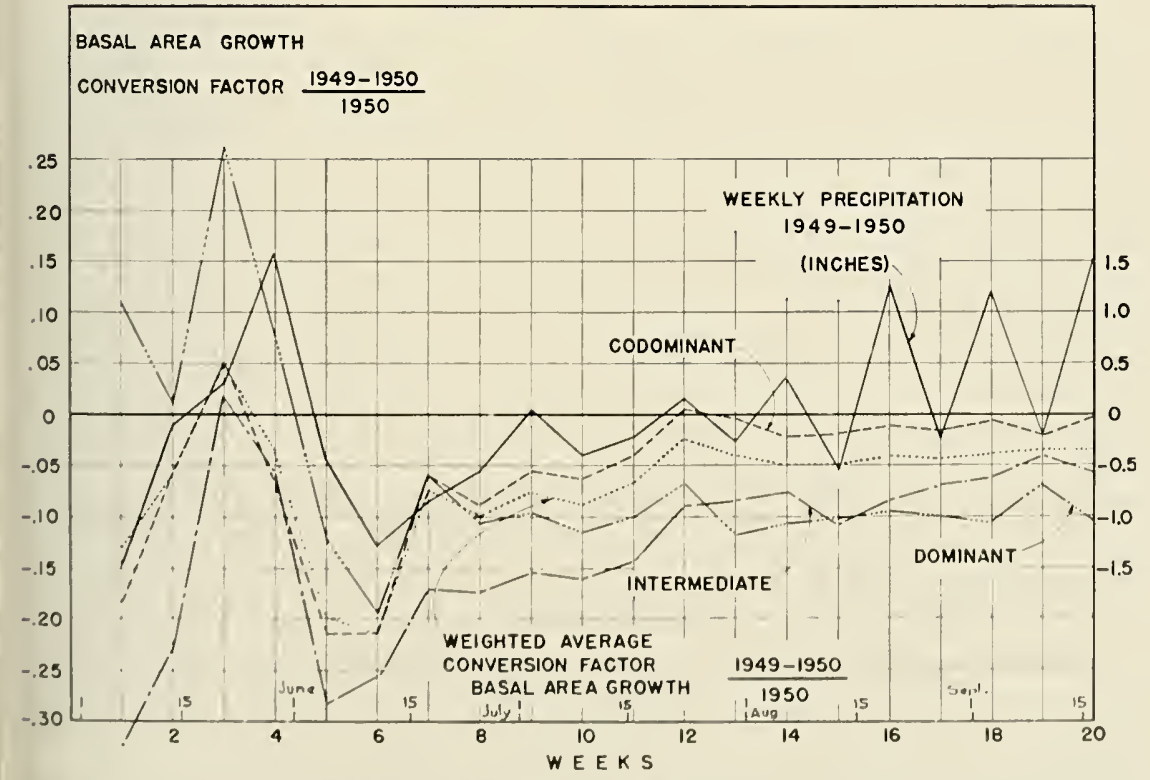

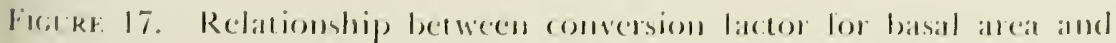
differences in weekly precipitation between 19.19 and 1950. 
In order to investigate this further, the conversion factor for basal area growth between the two seasons has been plotted, along with the differences in weekly precipitation between 1949 and 1950. This is shown in Figure 17. The conversion factor for basal area growth is determined by the formula:

$$
\text { Basal area growth for } 1949 \text { - Basal area growth for } 1950
$$

\section{Basal area growth for 1950}

These curves show a great similarity up until the fourteenth week of the growing season. After this time the basal area convversion factor is almost constant, but there are great fluctuations in the difference between the weekly precipitation for the two years. Since the basal area growth has almost stopped after the fourteenth week of the growing season, the influence of precipitation on basal area growth is only minor. Applying statistical analysis of the trend of the curves for the first thirteen weeks of the growing season, indicates that the relationship between the two curves has a correlation coefficient of .784. This is highly significant.

\section{Results and Discussion}

\section{A. Crown Release Classifications}

As previously mentioned, 193 trees were used for measurements at the beginning of the experiment. Seven trees were damaged in the summer of 1949 as a result of road construction and were eliminated. The 186 remaining trees were divided into three main groups: 51 for control, 68 for release during the dormant season between 1949 and 1950, and 67 to be released during the growing season of 1950. The control trees were used for adjustment of variations between the two growing seasons. For this purpose the average growth of the control trees for each week during the 1949 growing season was compared with the corresponding average for the 1950 growing season, as shown in Figure 18. By means of the formula (C), previously shown, a correction factor for the growth of each week of the 1950 growing season was found.

From calculations it was found that it was not feasible to use the extent of the crown circumference that was released as a measure for crown release. Since some of the interference along the circumference might extend almost to the top of the crown of the sample tree, in other cases, it might be an interference on only the lower branches even if the amount of interference along the circumference was the same. 


\section{COMPOSITE CURVE}

FOR

$5 I$ CONTROL TREES

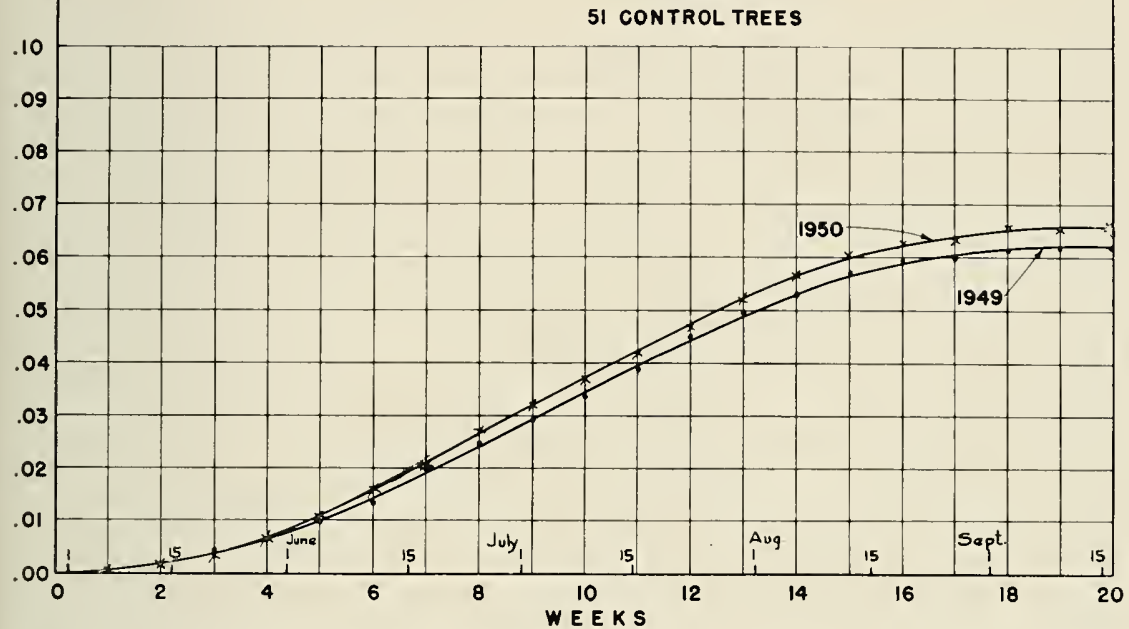

FigURE 18. Weekly basal area growth of 51 control trees in 1949 and 1950.

Based on the formula for the crown surface and the amount of crown release the sample trees would get after some of the interference was removed, the sample trees were divided into several classes. The two main classes included the trees that received release during the dormant season between the 1949 and 1950 growing season, and the trees that were released during the latter part of June, 1950. Each of these main classes was divided into the percentage of crown surface that was released. The classifications used were: (1) less than 12.5 per cent, (2) 12.5 to 37.4 per cent, (3) 37.5 to 62.4 per cent, and (4) 62.5 to 87.4 per cent. The average basal area growth for each week was found for these classifications for both 1949 and 1950. By means of the correction lactors detemined by formula (C) the 1950) figures were adjusted for weekly variations in growth between the two growing scasons using the following formula:

(1950) reading) - (conversion lactor $\times 1950$ reading $)=$ Adjusted reading

l). CROWN RHAASE DURING; TII. DORMANI SHASON

In order to compare the conceded 1950 growth with the 19.19 growelh on basal ancal, this relationship is shown for the dilferent classes

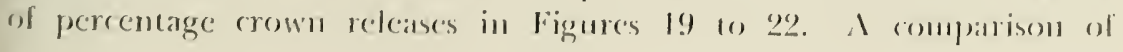




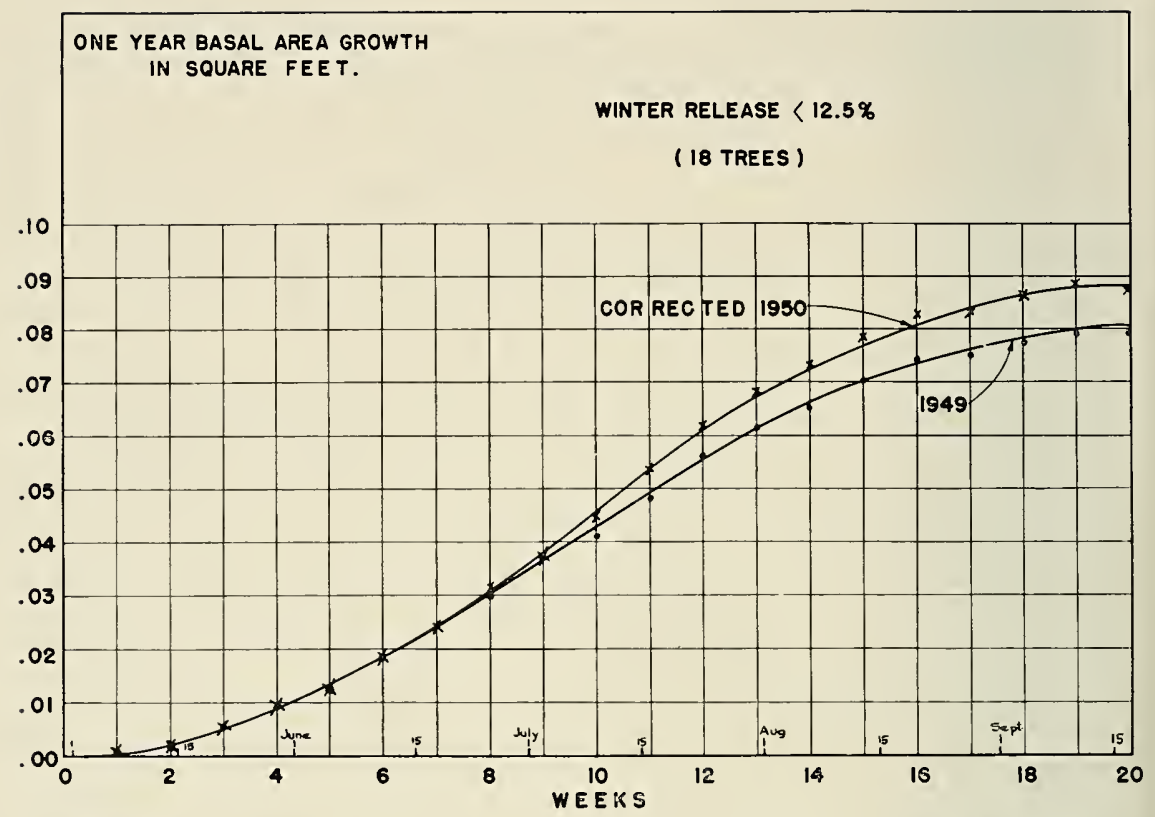

FigUre 19. Weekly accumulative basal area growth in 1949 and 1950 of 18 trees given winter release of less than 12.5 per cent.

Figures 19 to 22 with each other, shows that the larger the percentage crown release during the dormant season, the larger the percentage growth difference of basal area at the end of the growing season. Figure 19 shows that the average basal area growth for trees that received less than 12.5 per cent crown release during the dormant season between 1949 and 1950 have had an increase in growth during 1950 of about 11.4 per cent. The trees that received a crown release of from 62.5 to 87.4 per cent grew 54.0 per cent more on the basal area during 1950. Although the faster growth was not noticeable until the eighth week of the 1950 growing season on the trees that received less than 12.5 per cent crown release, the increased growth started gradually earlier on the trees what were released more. On the trees that received releases ranging from 62.5 to 87.4 per cent, the increased growth was already measurable during the third week of the growing season, or about the last week in May.

\section{Crown Release During the Growing Season}

As can be seen in Figures 23 to 26, the trees that were released during the latter part of June did not show as great an over-all increase on the basal area growth as the trees released during the dormant 
ONE YEAR BASAL AREA GROWTH

IN SQUARE FEET.

WINTER RELEASE $12.5-37.4 \%$

( 28 TREES)

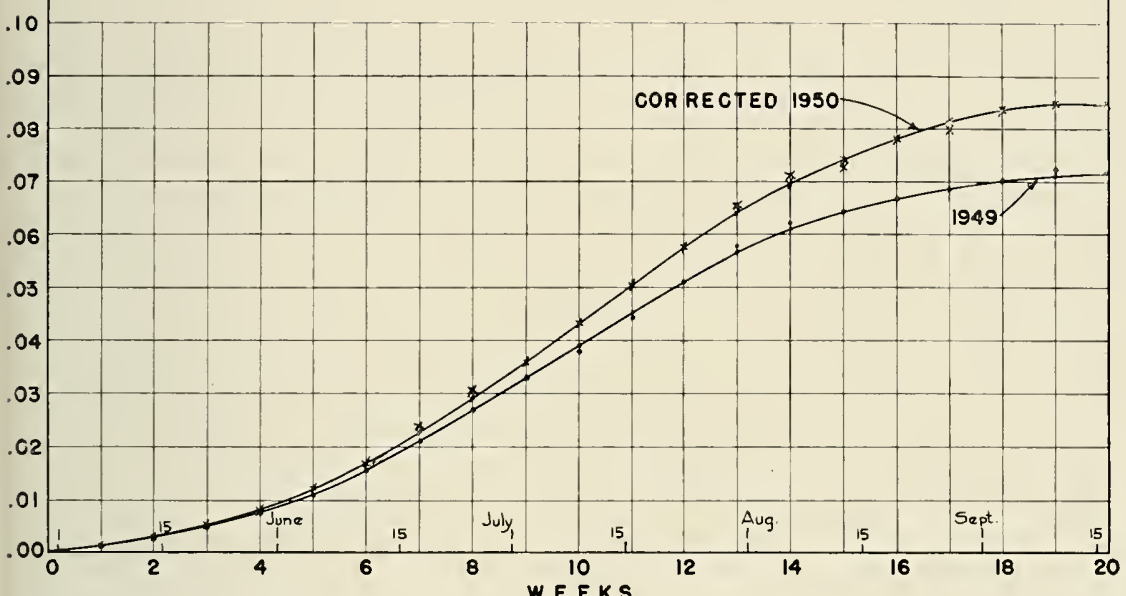

Figure 20. Weekly accumulative basal area growth in 1949 and 1950 of 28 trees given winter release of 12.5-37.4 per cent.

ONE YEAR BASAL AREA GROWTH

IN SQUARE FEET.

WINTER RELEASE $37.5-62.4 \%$

( 18 TREES)

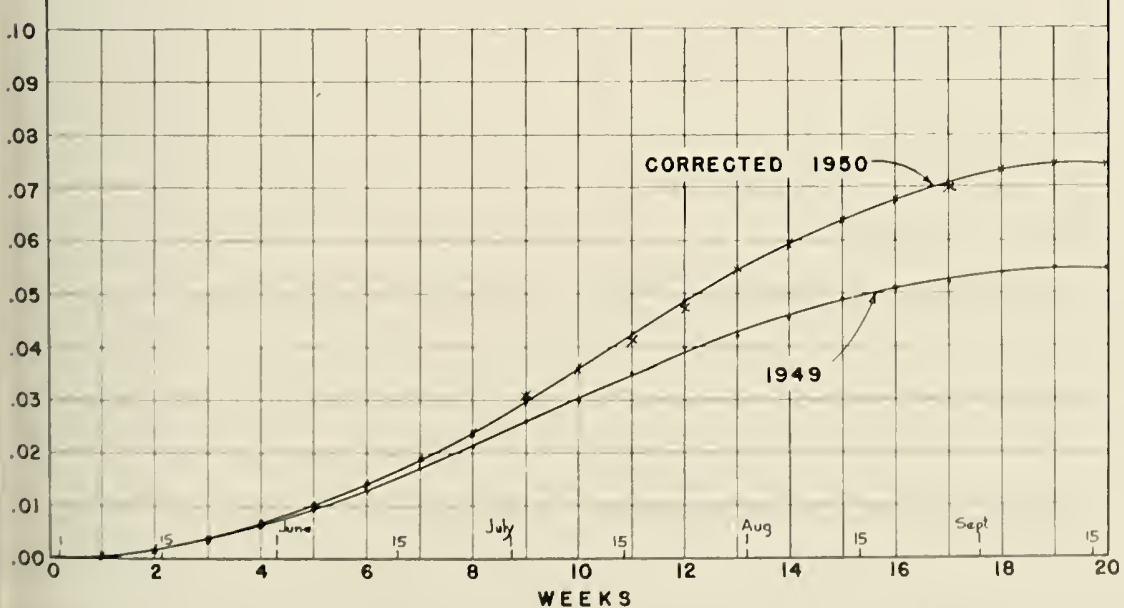

lino k1. 21. Weckly accumulative basal area growth in 1919 and 1950 of 18 arees given winter release of $37.5-62.4$ per cent. 


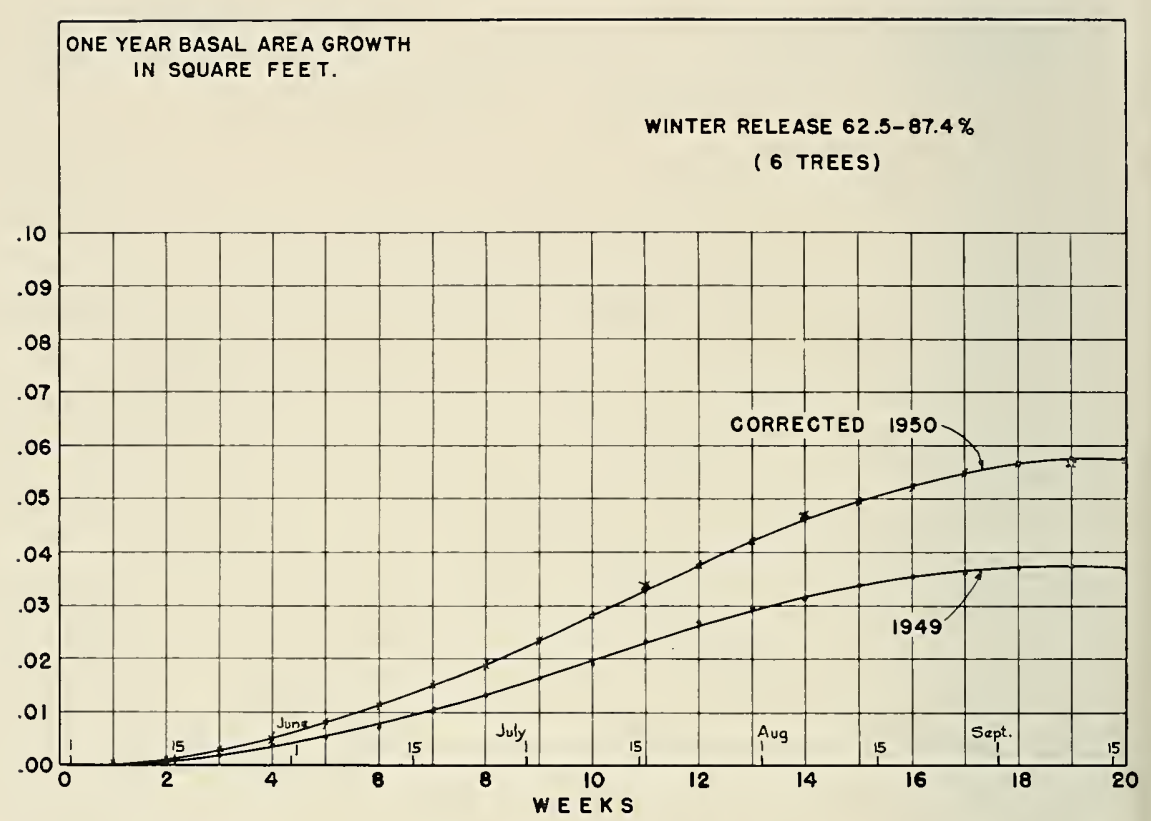

Figure 22. Weekly accumulative basal area growth in 1949 and 1950 of 6 trees given winter release of 62.5-87.4 per cent.

season, since the former had only part of the 1950 growing season under released condition. The increase in basal area growth during 1950 for the trees that received less than 12.5 per cent release during the summer was 9.7 per cent. The trees that had crowns released between 62.5 and 87.4 per cent, increased 26.0 per cent in basal area growth. It is interesting to note that even though most of the leaves were out on the trees before they were released, and although these leaves already had completed their cell structure, the trees that received the most crown release increased the most in basal area growth compared to the 1949 growing season. This agrees with the findings of Heinicke and Childers (12). They showed that the rate of photosynthesis for an entire apple tree increased progressively with increase in light intensity. These investigators also showed that many of the interior leaves received 1 per cent or less of the light received by the peripheral leaves. Therefore, even in full sunlight many of the leaves on a tree do not photosynthesize at their maximum capacity. Hence the greater the intensity of the incident light, the greater average rate of photosynthesis per unit of leaf area. Meyer and Anderson (19) state that "total photosynthesis per tree increases with increased illumination up to the maximum possible sunlight intensity." M Mller (22) states that "the constant factor as far as the number of leaves per hectare is 
concerned, may be explained in this way that the light necessary for the $\mathrm{CO}_{2}$ assimilation is rather close to the minimum compared to the other growth factors."

In line with the foregoing findings, the increased growth of the trees that were released during the growing season may be explained in this way: before release many of the leaves were assimilating below their capacity. After the release they received higher light intensity. This brought the assimilation of these leaves closer to their maximum production. During the years following release, the basal area growth will be further increased, as will be shown later from a stem analysis of tree No. 101. This further increase may be attributed to the enlargement of the crown, which causes the crown surface to increase. The relation between crown surface and basal area growth has already been established, as shown in Figure 11.

The release of the sample trees took place cluring the latter part of June and was finished before the measurements were taken for the growth of the eighth week. In Figures 23 to 26 it will be noted that already on the measurements for the eighth week an increased growth reaction has taken place. This increased growth continued to the end of the growing season. At that time the trees that were released the most showed the greatest percentage increase over their 1949 growth.

ONE YEAR BASAL AREA GROWTH IN SQUARE FEET.

SUMMER RELEASE $<12.5 \%$

( 13 TREES)

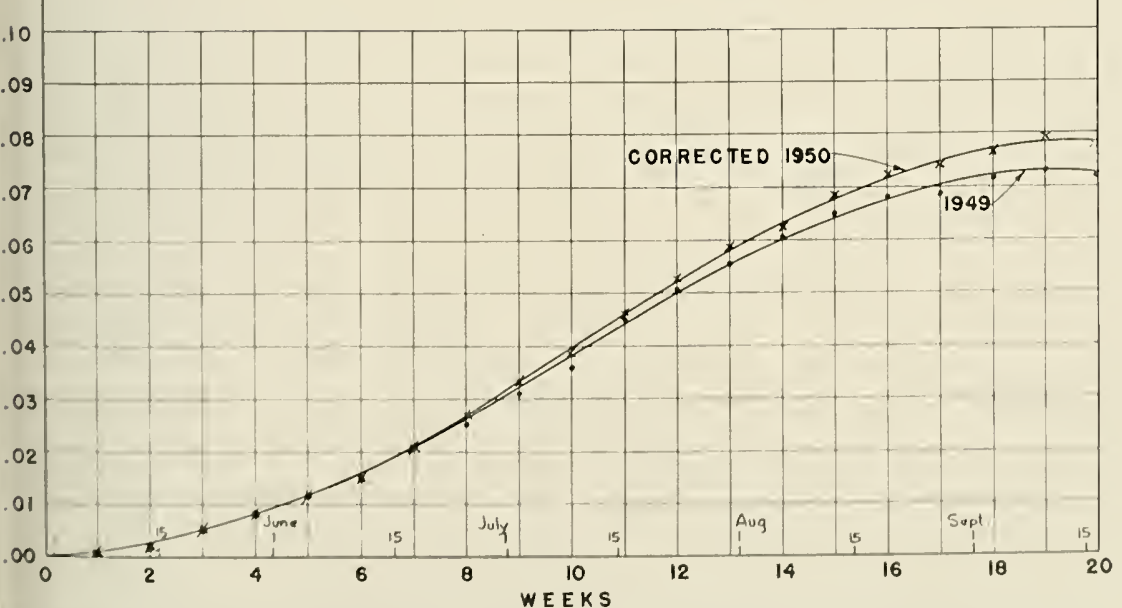

Fic, R1. 2\%. Weekly accumulative basal area growtle in 1919 and 1950) of 1.3 crees given smmmer release of less than 12.5 per cemt. 
ONE YEAR BASAL AREA GROWTH

IN SQUARE FEET.

SUMMER RELEASE $\quad 12.5-37.4 \%$

( 40 TREES)

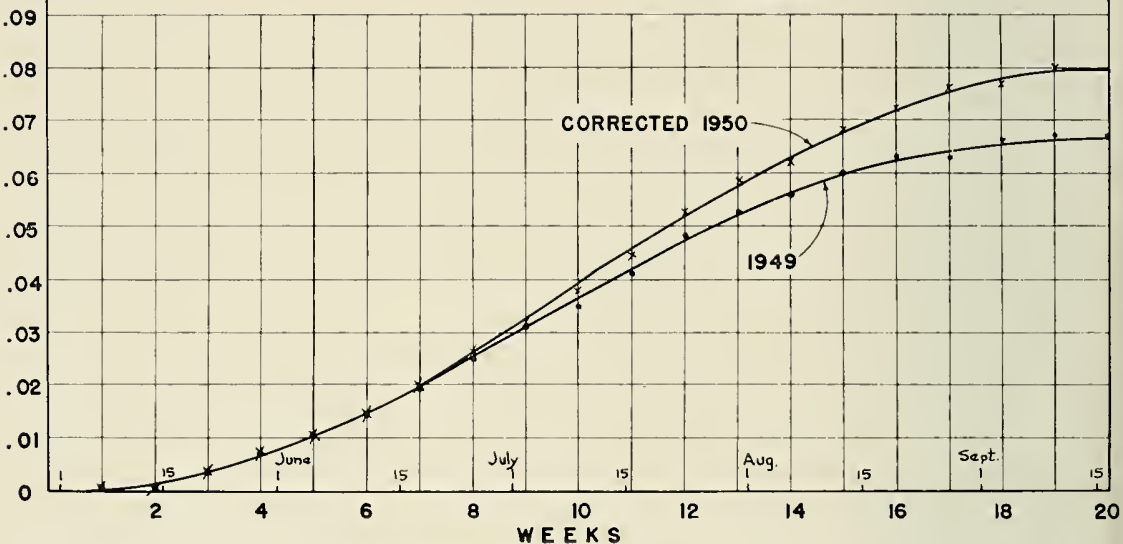

Figure 24. Weekly accumulative basal area growth in 1949 and 1950 of 40 trees given summer release of 12.5-37.4 per cent.

ONE YEAR BASAL AREA GROWTH IN SOUARE FEET.

SUMMER RELEASE $37.5-62.4 \%$

(8 TREES)

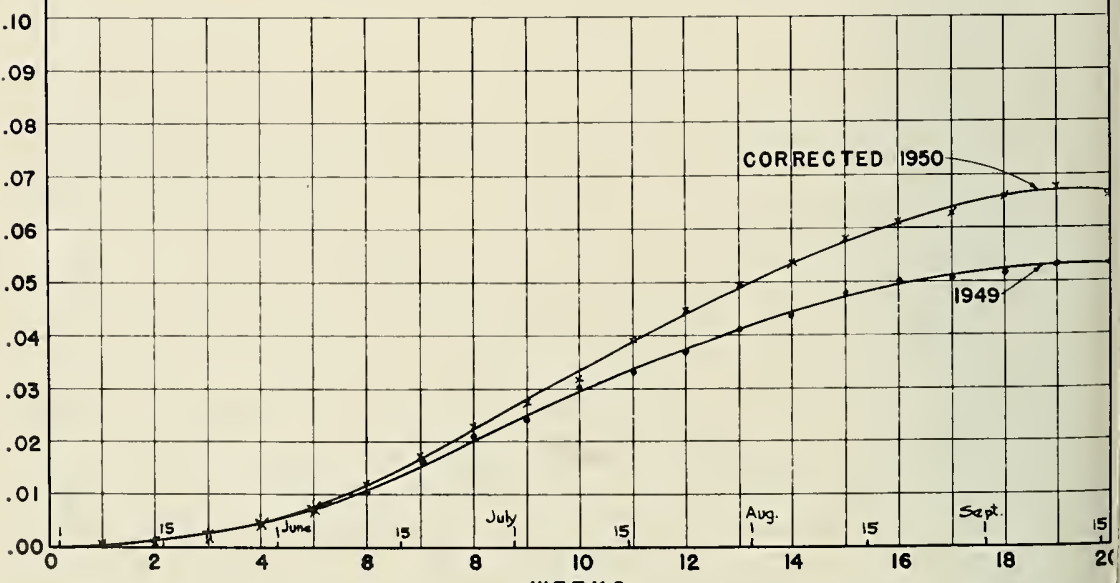

WEEKS

Figure 25. Weekly accumulative basal area growth in 1949 and 195( of 8 trees given summer release of $37.5-62.4$ per cent. 


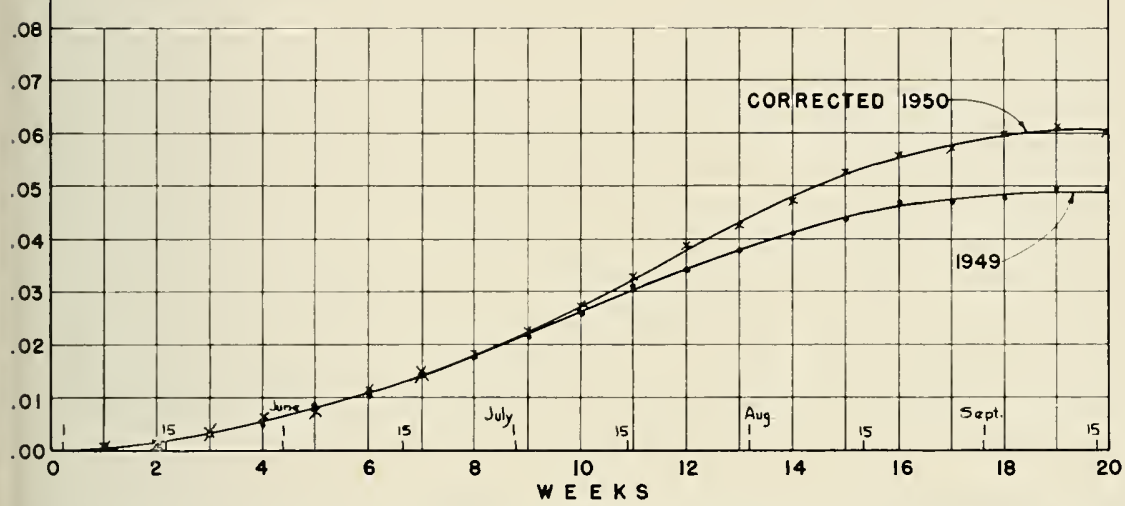

FiguRe 26. Weekly accumulative basal area growth in 1949 and 1950 of 5 trees given summer release of 62.5-87.4 per cent.

This immediate response to release checks very well with the lindings of Stephens and Spurr (26) who, in red pine, found that the increased growth rate could be noted within twenty-four hours after release.

These results show that for various degrees of release there is a corresponding increased rate of basal growth increasing with the anount of crown surface released. Consequently, it has not been possible to determine any stagnation or decrease in growth rate due to a shock reaction caused by a sudclen release of the simple trees used in this experiment.

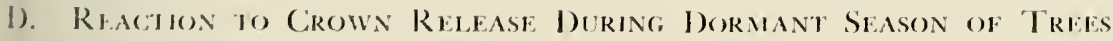
(OF I)HFIRINT CROWN CIAASSES

In order to further investigate the reaction on the individual trees (1) varions degrees of cromen release during both the domamt season and the growing seasom, the trees were divided into crown classes. The: threc main gromps were comtrol trees, winter-released treces, and summerereleased eress. The: were all divided into elomimant, colominame, and

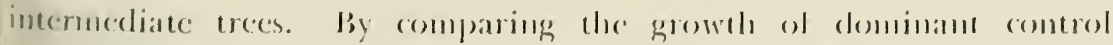

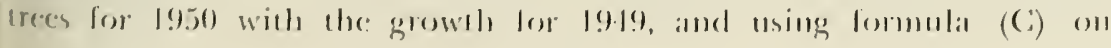


page 28, the correction factors for the different weeks of the growing season were found. These correction factors were applied to the weekly 1950 growth for the dominant trees that were released during the dormant season and for those released during the growing season of 1950. The same procedure was used for codominant and intermediate trees.

In Figures 27, 28, and 29, the corrected 1959 growth is shown with the growth for 1949 for dominant trees that respectively have received a winter release of less than 12.5 per cent, 12.5 to 37.4 per cent, and 37.5 to 62.4 percent. From these curves it is evident that the more the dominant trees are released during the dormant season, the more they grow on the basal area during the following growing season. The difference for dominant trees between the corrected weekly growth figures for 1950 and 1949 weekly growth was placed over the 1949 growth and the percentage growth increase was found. This relationship is shown in Figure 30, which indicates that by the end of the growing season the trees which had less than 12.5 per cent of their crown released, grew 8.5 per cent more than they did in 1949. The trees that received a crown percentage release of between 12.5 and 37.4 per cent, increased 12.5 per cent, whereas the trees that were released between 37.5 and 62.4 per cent, increased 46.0 per cent. Although

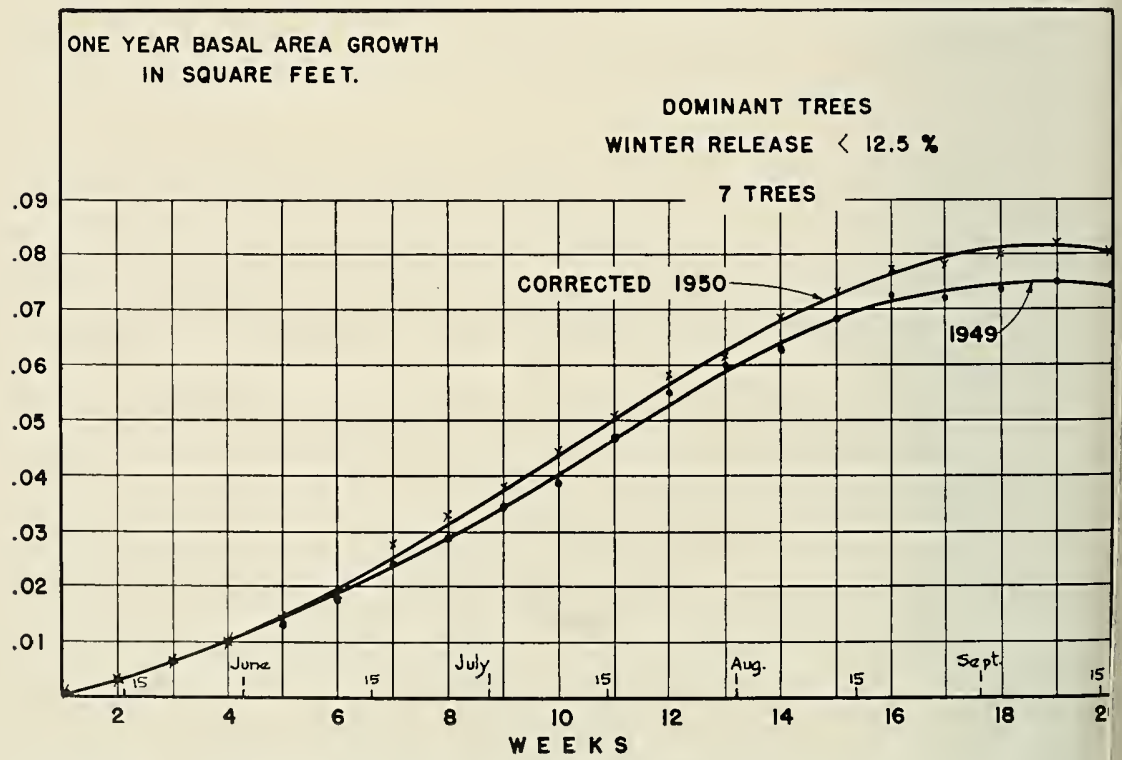

Figure 27. Weekly accumulative basal area growth in 1949 and 195 of 7 dominant trees given winter release of less than 12.5 per cent. 


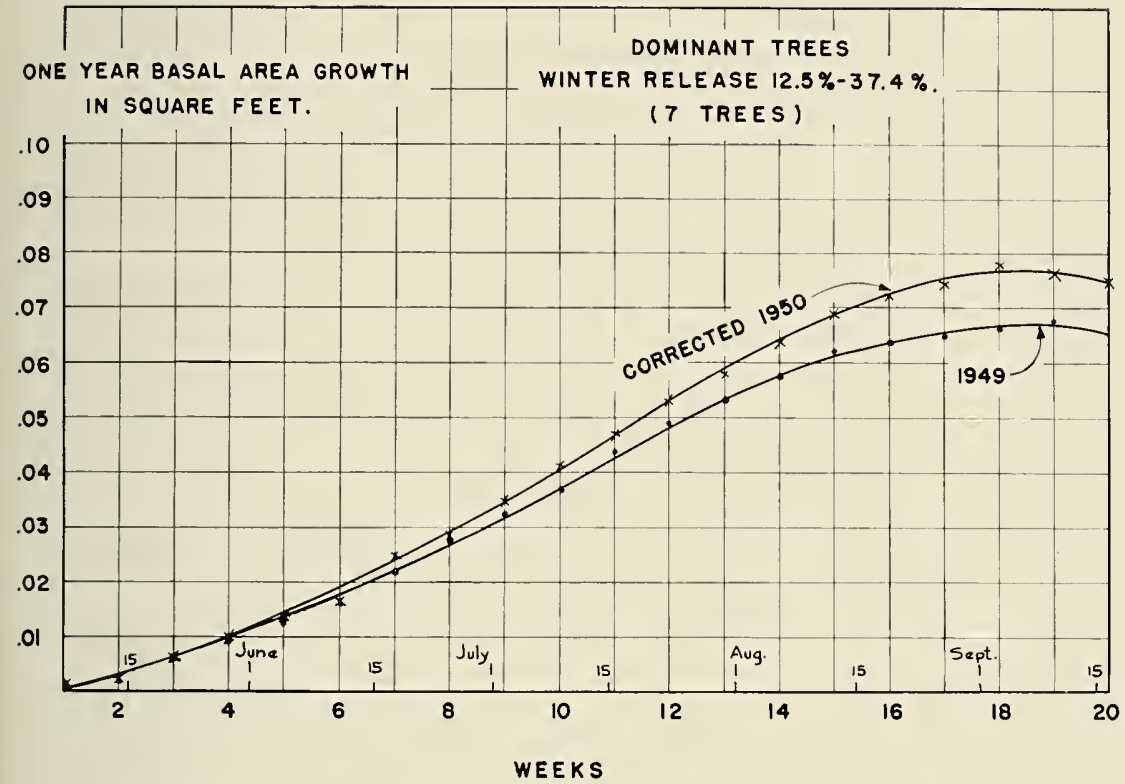

FIGURE 28. Weekly accumulative basal area growth in 1949 and 1950 of 7 dominant trees given winter release of 12.5-37.4 per cent.

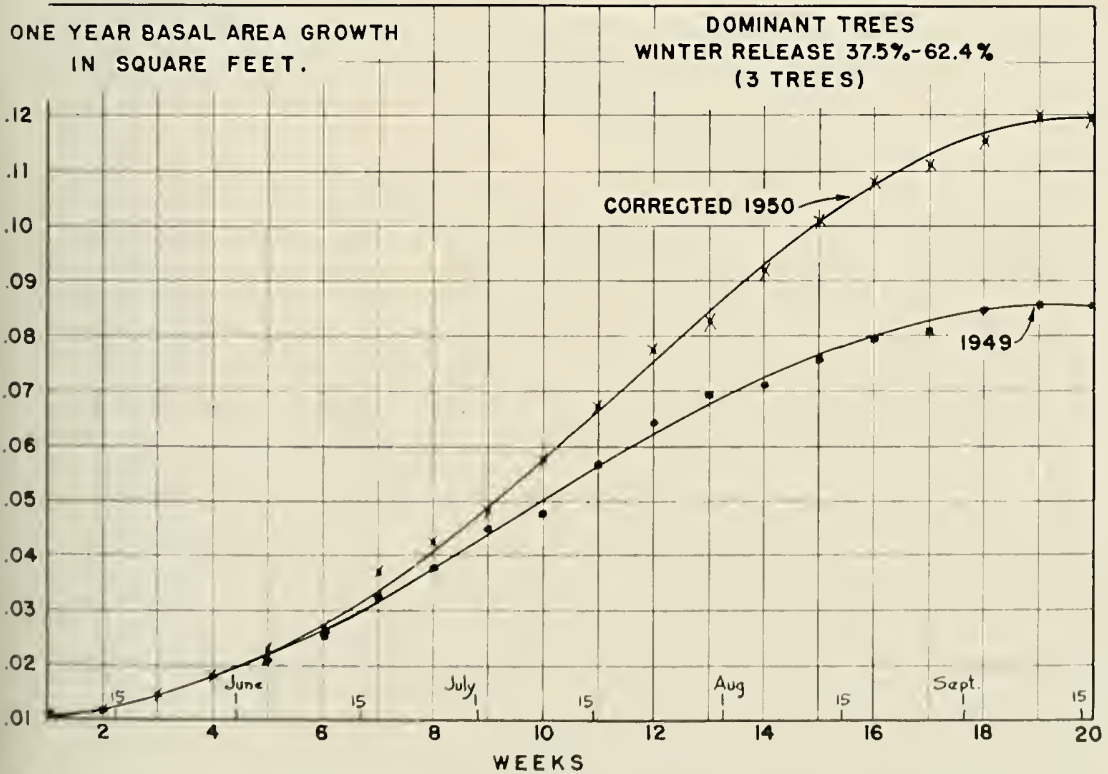

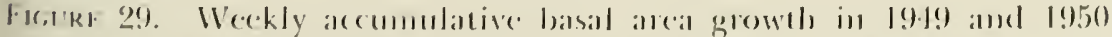

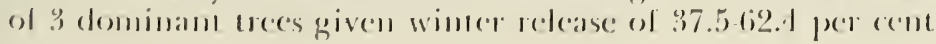




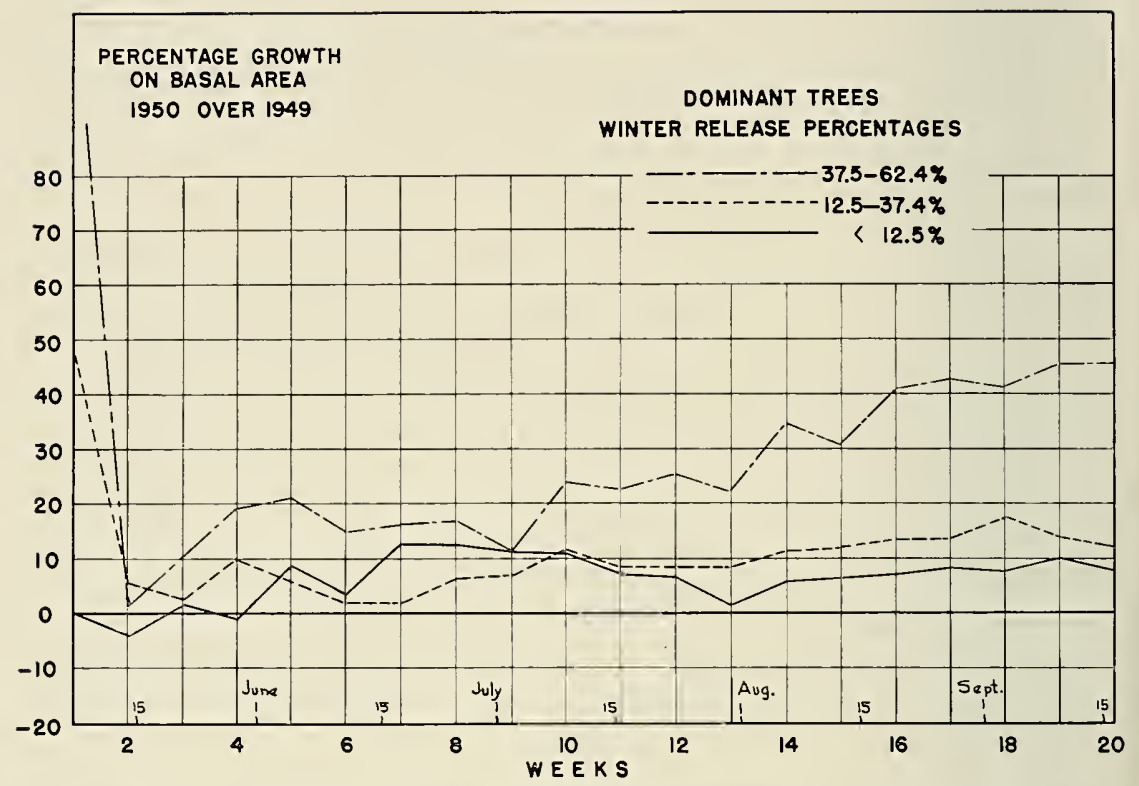

Figure 30. Percentage weekly basal area growth in 1949 and 1950 of dominant trees given different percentages of winter release.

these figures cannot be deemed conclusive because only relatively few trees fell in this category, they are indicative of the effect that will take place after different percentages of release of crown surfaces of dominant trees have been made.

Figures 31, 32, 33, and 34 show the growth of codominant trees that received different amounts of crown release during the dormant season. The release classifications that are represented in these figure, are crown releases less than 12.5 per cent, between 12.5 and 37.4 per cent, and between 37.5 and 62.4 per cent. As in former figures, the 1950 growth is corrected based on the differences in growth of codominant control trees during the 1949 and 1950 growing season. The result; may be considered rather indicative, since all the classifications are represented by a fair number of trees. As will be noticed from the figures, there is no difference between the growth of 1949 and 1950 until the sixth week. After that there is a steadily increasing difference between the two growing seasons corresponding with the amount of release the crowns have received. Figure 42 shows the difference between the basal area growth cluring the two seasons expressed as a percentage over 1949 growth. As will be noted, there are grat percentage variations during the first five weeks. This is understandable, 
ONE YEAR BASAL AREA GROWTH

IN SOUARE FEET.
CODOMINANT TREES

WINTER RELEASE $<12.5 \%$

( 9 TREES)

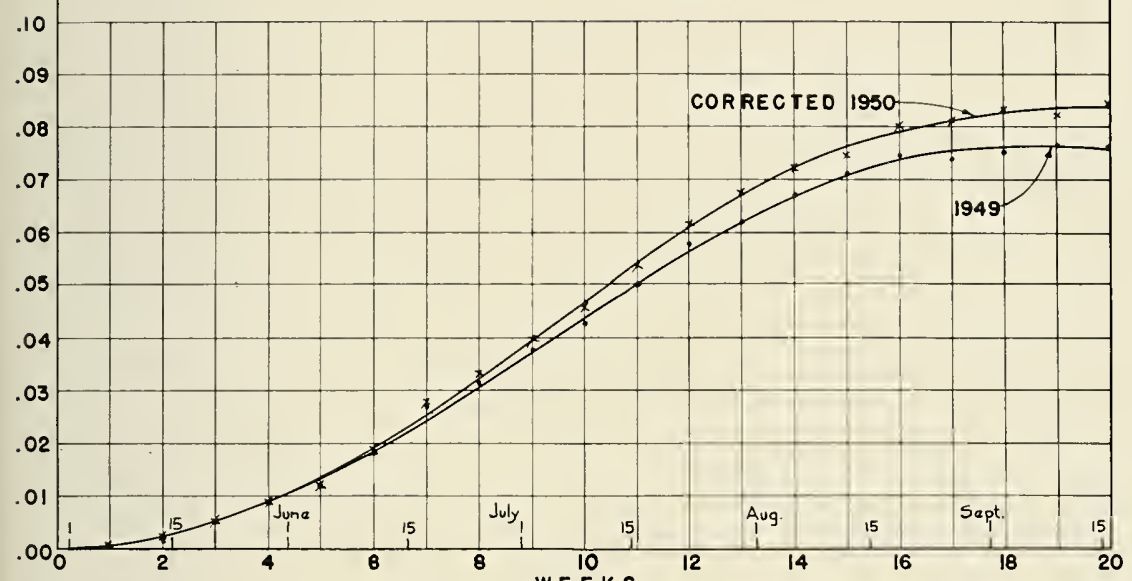

Figure 31. Weekly accumulative basal area growth in 1949 and 1950 of 9 codominant trees given winter release of less than 12.5 per cent.

ONE YEAR BASAL AREA GROWTH

IN SQUARE FEET.

CODOMINANT TREES

WINTER RELEASE $12.5-37.4 \%$.

(17 TREES)

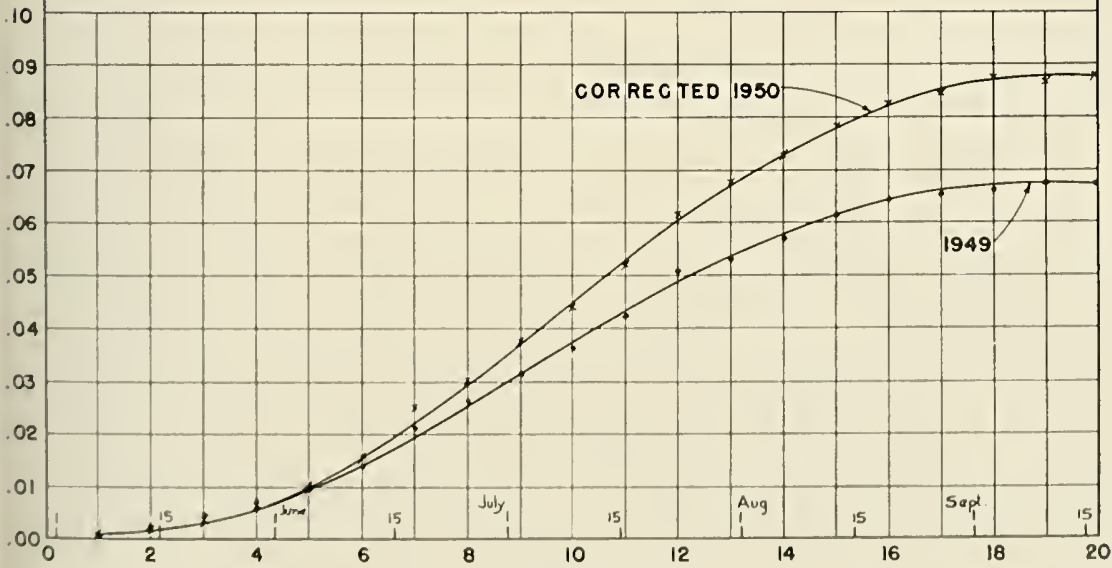

WEEKS

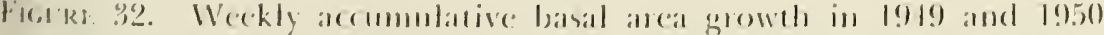
of 17 codominant trees given winter release of $12.5-37.1$ per rent. 
ONE YEAR BASAL AREA GROWTH

IN SOUARE FEET.
CODOMINANT TREES

WINTER RELEASE $37.5-62.4 \%$

(10 TREES)

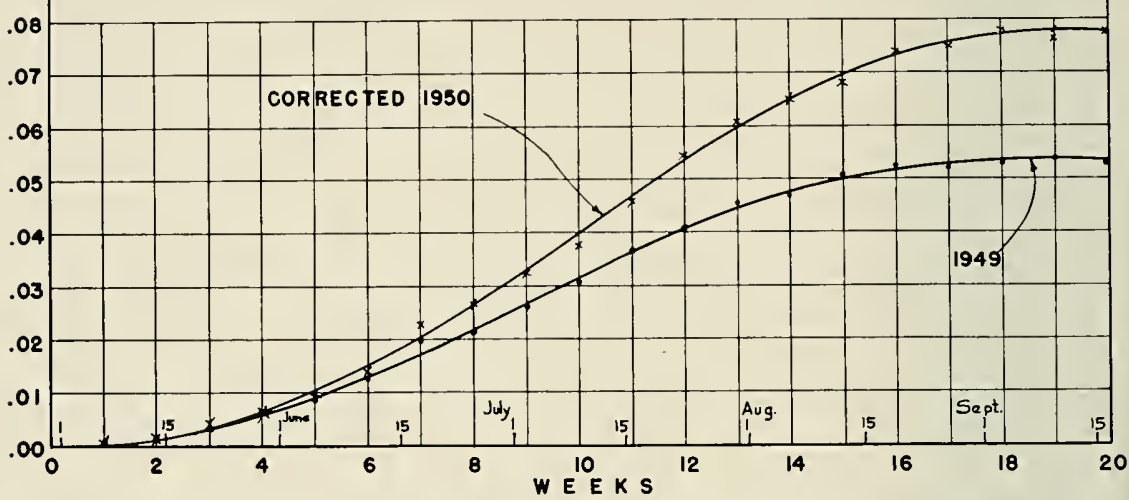

Figure 33. Weekly accumulative basal area growth in 1949 and 1950 of 10 codominant trees given winter release of 37.5-62.4 per cent.

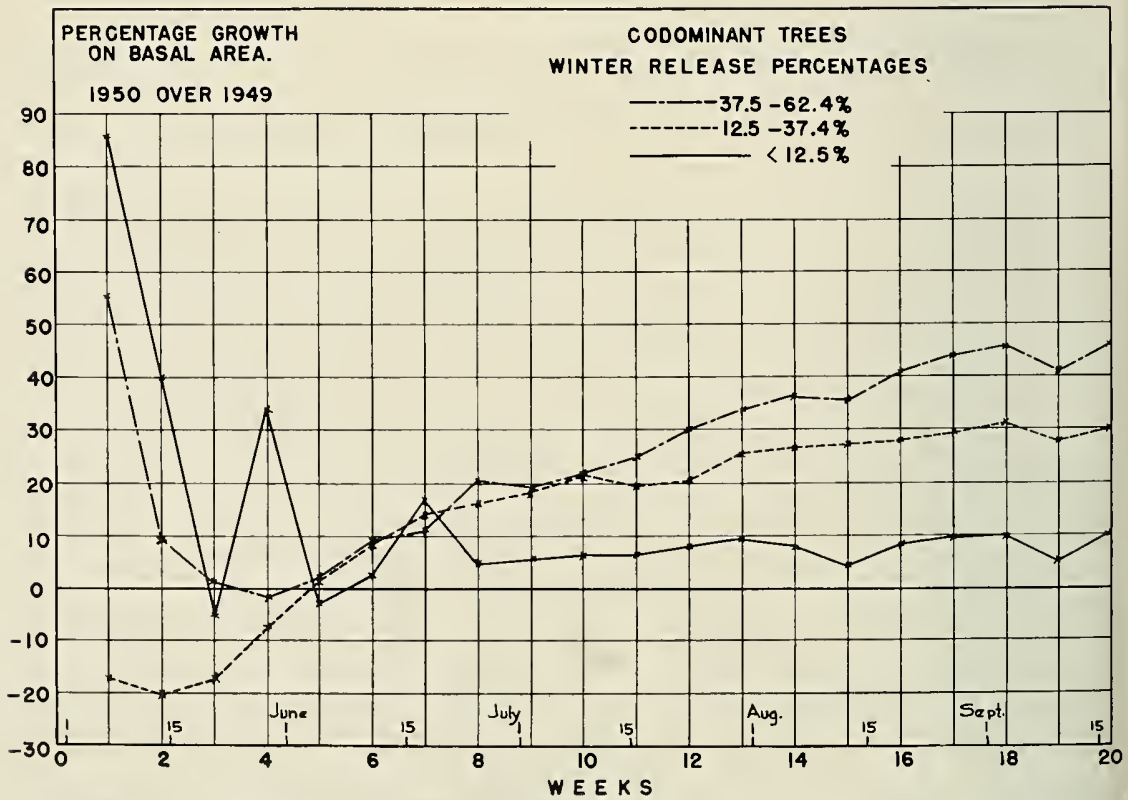

Figure 34. Percentage weekly basal area growth in 1949 and 1950 of codominant trees given different percentages of winter release. 
since small variations at that stage will represent large percentage differences. Therefore, not until the growirg season gets underway, or at about the fifth or sixth week, will the curves be indicative of the differences in growth of the three classifications of release. It will be noted that codominant trees that receive the most crown release wiil grow the most in basal area during the growing season following the release.

Figures 35, 36 and 37 represent the growth of intermediate trees that have received different percentages of crown releases during the dormant season. The corrected 1950 growth was obtained by means of corrected factors from the 1949 and 1950 growth of intermediate control trees. Figure 35, representing intermediate trees having received crown releases between 37.5 and 62.4 per cent, shows no difference in growth between the corrected 1950 data and the growth for 1949 until about the ninth week of the growing season. Figure 36, however, iepresenting intermediate trees having received crown releases between 62.5 and 87.4 per cent, shows a difference in growth during the two growing seasons on the third week of the growing season. Since these two classifications are only represented by 2 and 4 trees respectively, these findings cannot be deemed conclusive. Figure 37 shows the percentage difference in growth on basal area based on corrected 1950

ONE YEAR BASAL AREA GROWTH

IN SQUARE FEET.
INTERMEDIATE TREES

WINTER RELEASE $37.5-62.4 \%$.

(2 TREES)

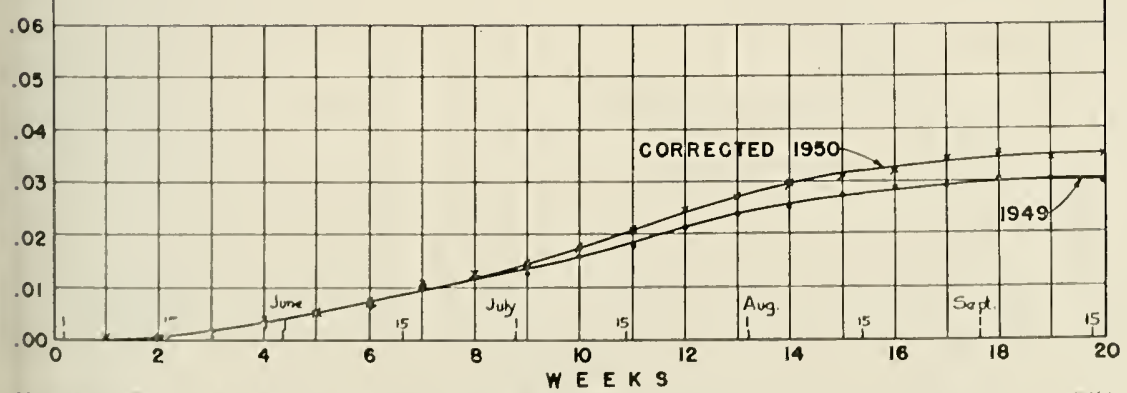

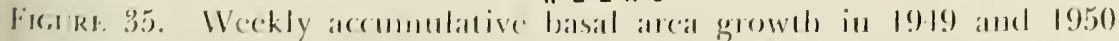

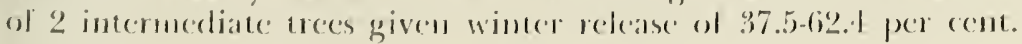


ONE YEAR BASAL AREA GROWTH

IN SQUARE FEET.

INTERMEDIATE TREES

WINTER RELEASE $62.5-87.4 \%$

( 4 TREES)

.08

.07

.06

.05

.04

.03

.02

.01

.00
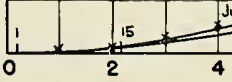

WE EKS

FIGURE 36. Weekly accumulative basal area growth in 1949 and 1950 of 4 intermediate trees given winter release of $62.5-87.4$ per cent.

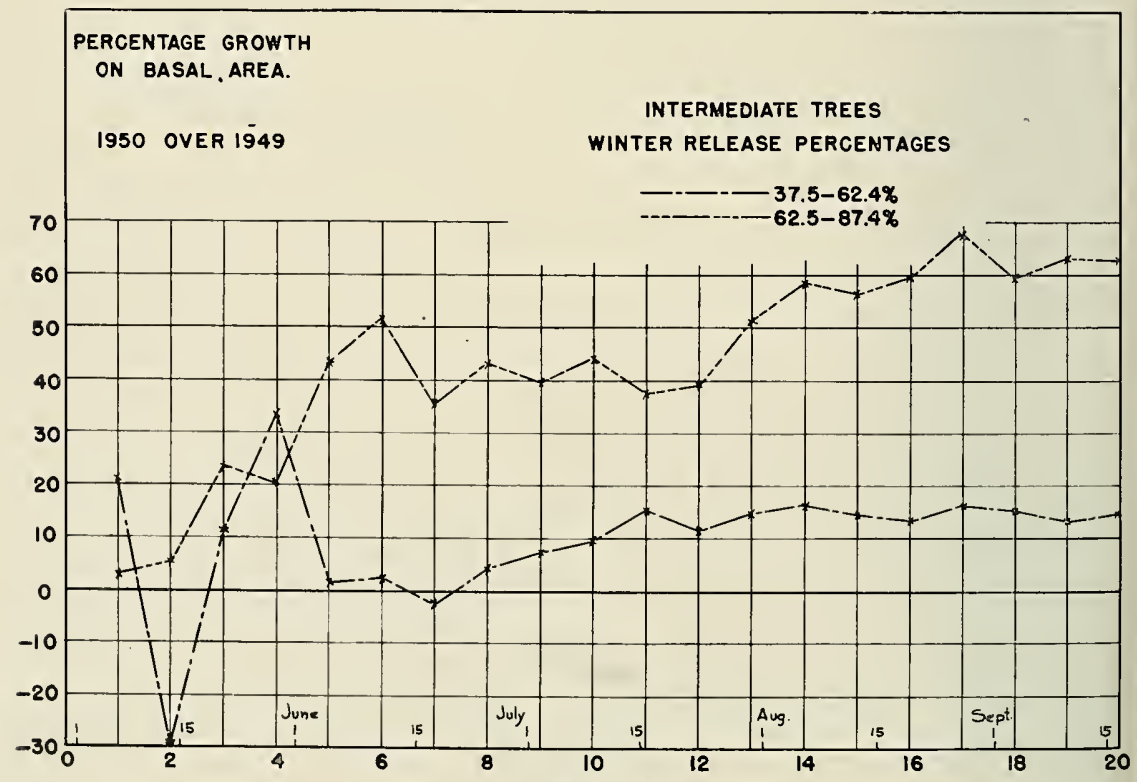

Figure 37. Percentage weekly basal area growth in 1949 and 1950 of intermediate trees given different percentages of winter release. 
measurements over 1949. The pattern here also is irregular until the seventh week, after which the trend in growth shows a remarkable difference. Because of the feri sample trees in these classifications, the results cannot be termed significant. The trend of the curves, however, shows that the greater the percentage of crown release received by the intermediate trees, the greater the increase in basal area growth cluring the growing season after release.

E. Reaction to Crown Release During Growing Season of Trees of Different Crown Classes

The following sets of curves represent the different crown classificasions and their reaction on basal area growth to various percentages of crown releases during the growing season. Figures 38 and 39, which show the average data of all the sample trees, indicate the amount of increase on basal area growth on winter-released and summer-released trees. These figures illustrate that the summer-released trees grew proportionally less than the trees that were released during the dormant season. The reason for this probably is that only part of the growing season remained after the release took place.

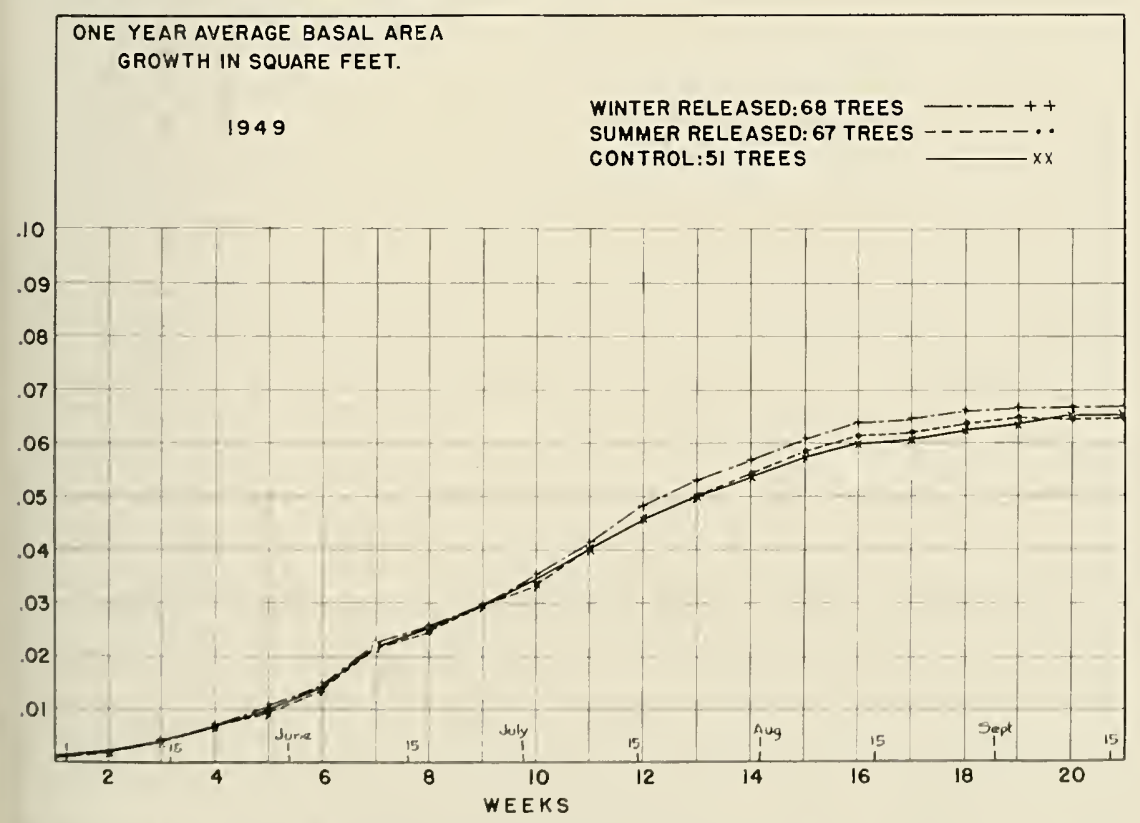

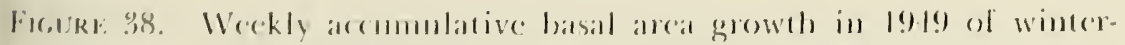

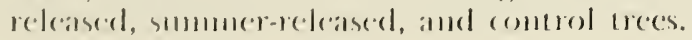




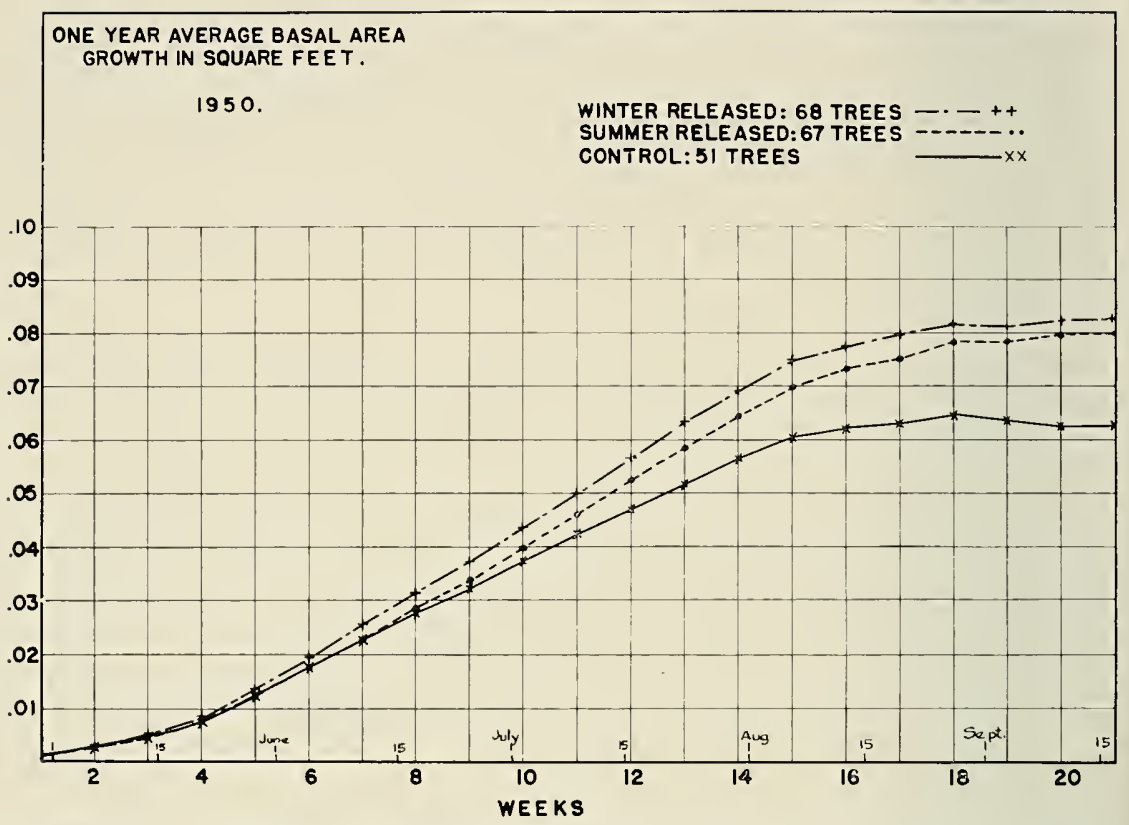

Figure 39. Weekly accumulative basal area growth in 1950 of winterreleased, summer-released, and control trees.

Figures 40,41 , and 42 show the reaction on basal area growth of dominant trees to crown releases of less than 12.5 per cent and between 12.5 and 37.4 per cent. Although the release took place during the seventh and eighth weeks of the growing season, no growth difference is noticeable on the dominant trees until the end of the fourteenth week for the trees that received the greater amount of release. On the dominant trees that received less than a 12.5 per cent crown release, the increased growth during the 1950 growing season does not show up until the end of the sixteenth week. This delay in reaction also is apparent in Figure 42, which shows that the percentage growth on basal area based on corrected 1950 growth over 1949 growth, runs along the zero line until the fourteenth and sixteenth weeks for the two classifications of crown release. By the end of the growing season, however, it shows that the dominant trees that have received the greatest percentage release of the crowns during the summer have the greatest percentage increase in basal area growth.

Figures 43, 44, 45, 46, and 47 show the reaction of codominant trees to various degrees of crown release during the growing season. It is interesting to note in Figure 43 that although the release of the crown took place during the seventh and eighth weeks of the growing 
ONE YEAR BASAL AREA GROWTH

IN SQUARE FEET.

DOMINANT TREES

SUMMER RELEASE $<12.5 \%$

( 4 TREES)

.10

.09

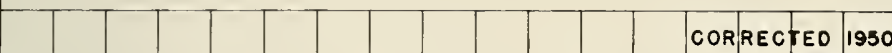

.08

.07

.06

.05

.04

.03

.02

.0
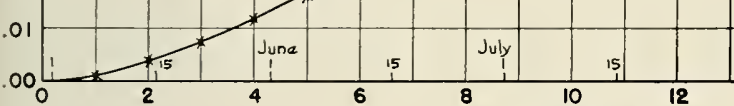

WEEKS

Figure 40. Weekly accumulative basal area growth in 1949 and 1950 of 4 dominant trees given winter release of less than 12.5 per cent.

ONE YEAR BASAL AREA GROWTH IN SOUARE FEET.
DOMINANT TREES

SUMMER RELEASE 12.5-37.4\%

(12 TREES)

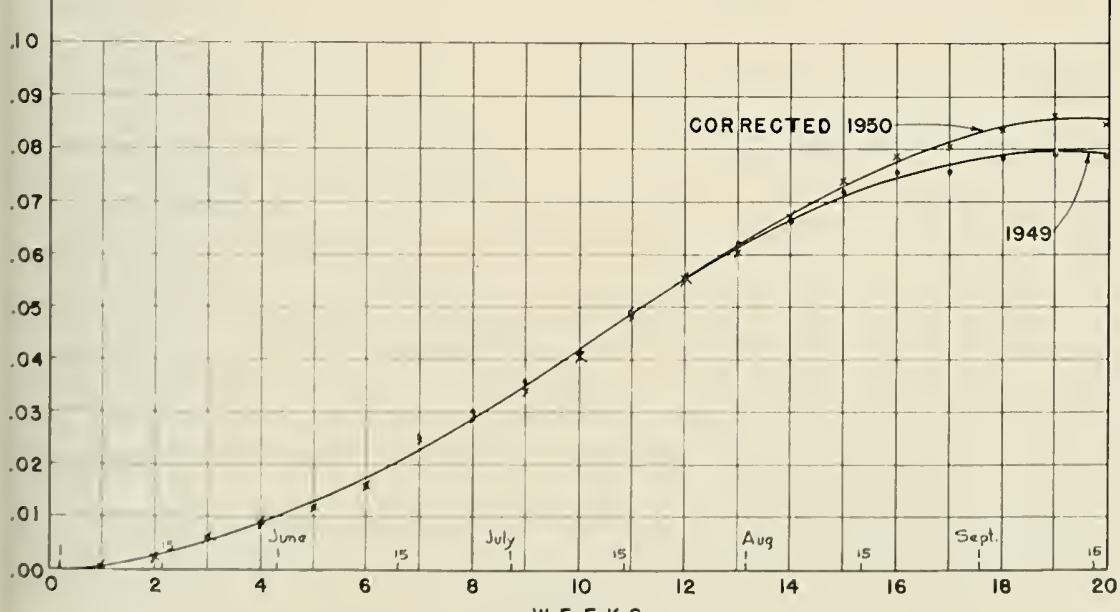

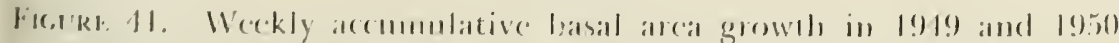

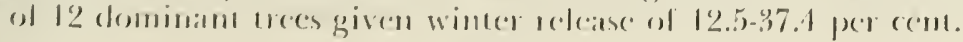




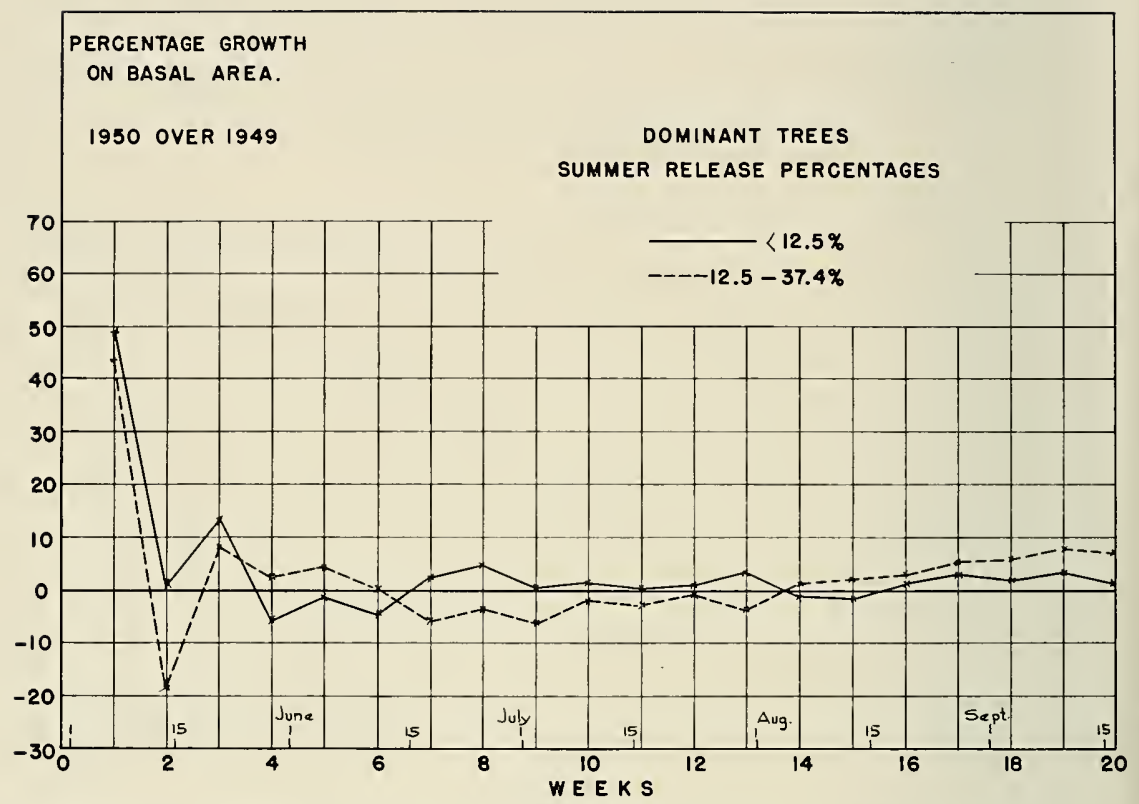

Figure 42. Percentage weekly basal area growth in 1949 and 1950 of dominant trees given different percentages of summer release.

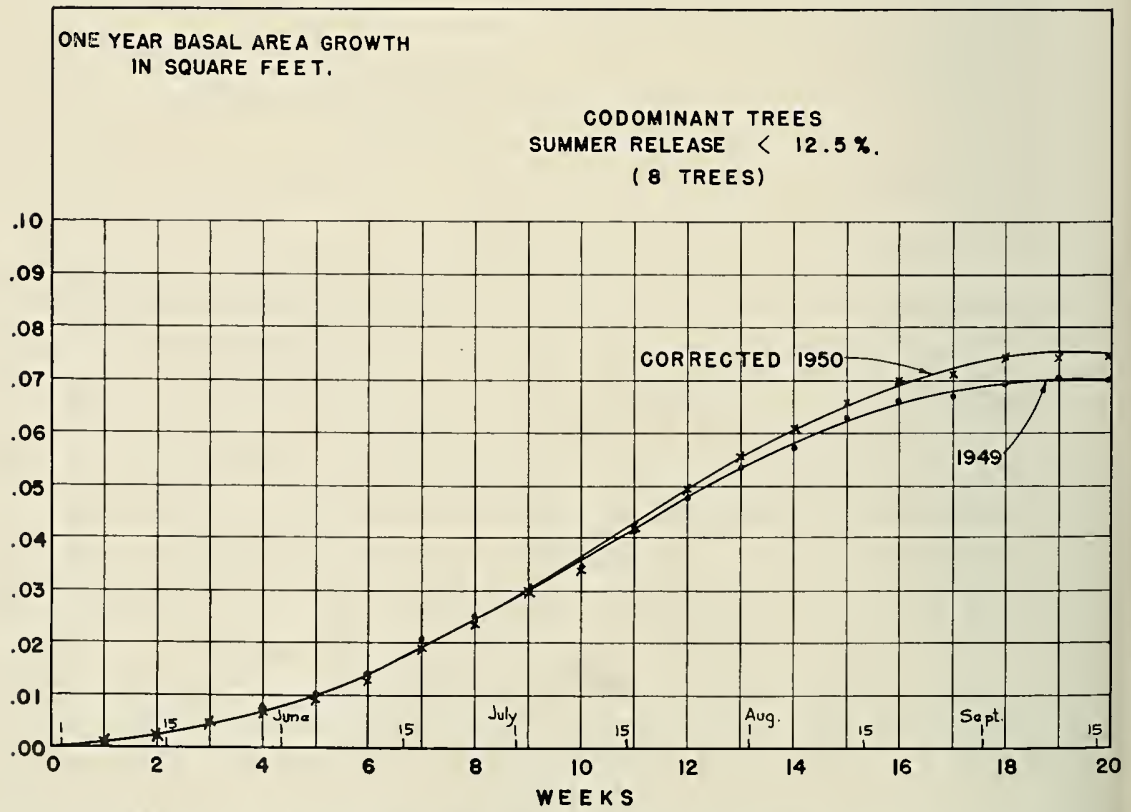

Figure 43. Weekly accumulative basal area growth in 1949 and 1950 of 8 codominant trees given summer release of less than 12.5 per cent. 


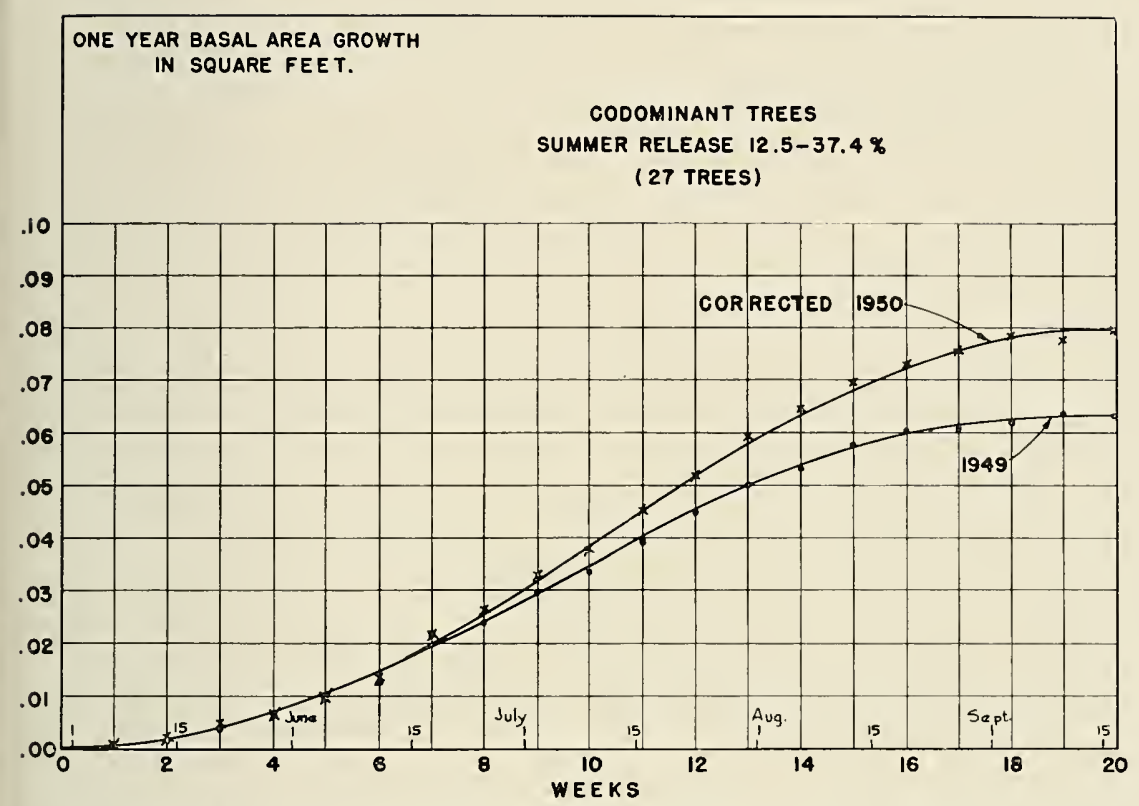

Figure 14. Weekly accumulative basal area growth in 1949 and 1950 of 27 codominant trees given summer release of 12.5 - 37.4 per cent.

ONE YEAR BASAL AREA GROWTH

IN SOUARE FEET.

CODOMINANT TREES

SUMAER RELEASE $37.5-62.4 \%$.

( 5 TREES )

.10

.07

.00

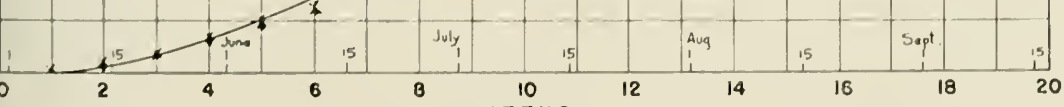

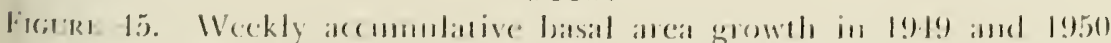
of 5 codominam arees given smmmer release of 37.5 - 
ONE YEAR BASAL AREA GROWTH

IN SOUARE FEET.

CODOMINANTS

SUMMER RELEASE $62.5-87.4 \%$

(4 TREES)

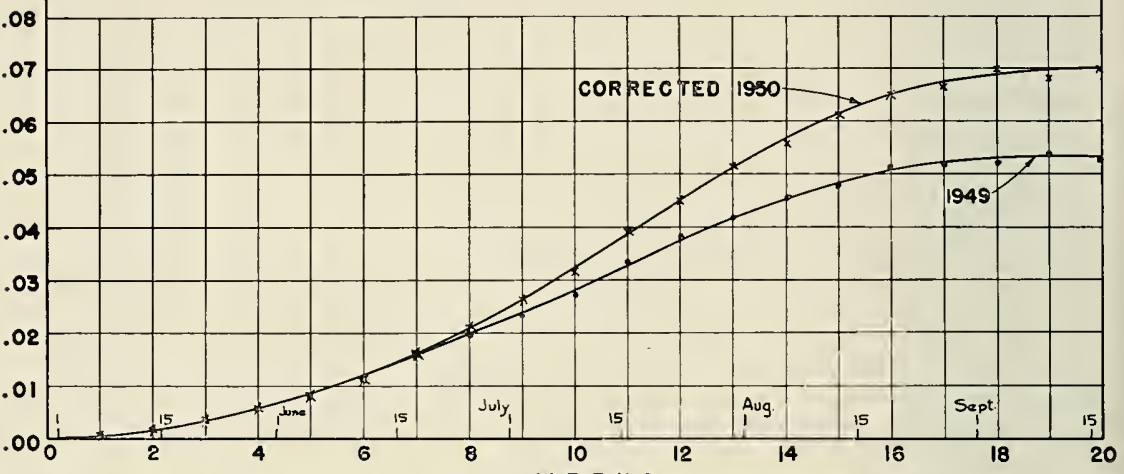

Figure 46. Weekly accumulative basal area growth in 1949 and 1950 of 4 codominant trees given summer release of $62.5-87.4$ per cent.

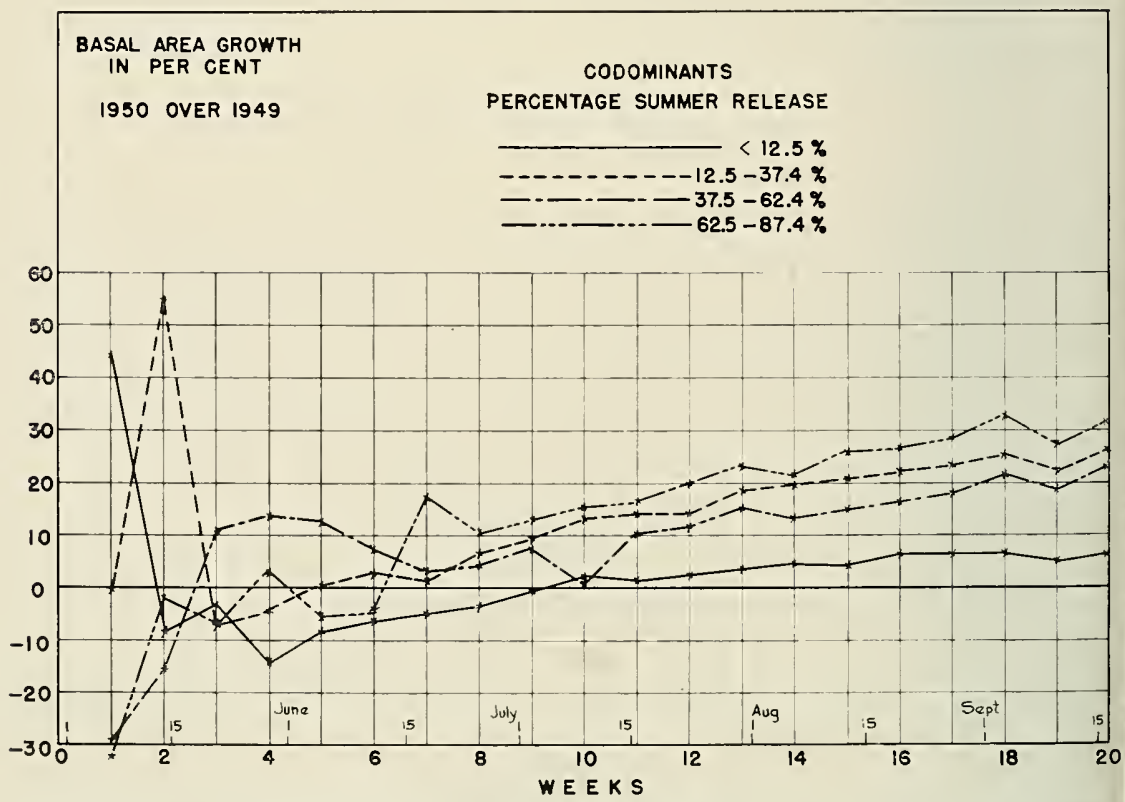

FigURE 47. Percentage weekly basal area growth in 1949 and 1950 of codominant trees given different percentages of summer release. 
season, there is no increased growth during 1950 until the tenth week on the trees that received a release of less than 12.5 per cent. For the other groups that received greater percentage releases of their crowns, the reaction is already noticeable on the measurements during the eighth week, only a few days after the release took place. Although the differences for the different percentages of release are considerable, the corrected 1950 growth on the basal area is much less compared to the winter-released codominant trees. Figure 47 shows the percentage growth on basal area-corrected 1950 growth over 1949 growth. The irregularities also are apparent here until about the eighth week, after which the curves show steady trends. It is apparent, however, that the percentage increase does not correspond to the percentage of crown release. This may be explained by the lack of representation in the crown release classes of 37.5 to 62.4 per cent, and 62.5 to 87.4 per cent, which contain only 5 and 4 trees, respectively.

Figures 48, 49, 50, and 51 show the difference in growth between corrected 1950 and 1949 growth for intermediate trees that had their crowns released during the growing season. Figures 48, 49, and 50 represent, respectively, releases from 12.5 to 37.4 per cent, 37.5 to 62.4 per cent, and more than 87.5 per cent crown releases. Although there are only 2 trees in each of these groups, the figures have been included in the discussion because they do give an inclication of the reaction of intermediate trees to crown releases during the growing season. As can be seen in Figures 48 and 49, the corrected 1950 growth showed greater values during the third week of the growing season as compared to the 1949 growth. Although no definite explanation can be given, it is possible that since these trees were growing under starvation conditions in regard to light and perhaps root competition, cutting of some trees to give other trees cromn release during the dormant season may have affected the trees in question. Such cuttings may have alfected root competition of the summer-released intermediate trees without affecting the light elensity of the crowns.

As (an be seen in figures 18,49 , and 50 , the great difference in basal area growth between the two growing seasons did not occur until after the eighth week. It is believed that the increascel growth rate of the intermediate trees alter sone of the neighboring trees have been cut is partly dere to relcase lrom root competition, and partly to the increased anesunt of light that reaches the crown. This problent will be disconssed biter on paige for.

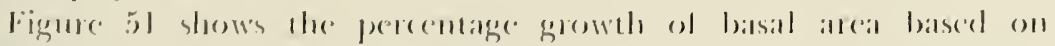

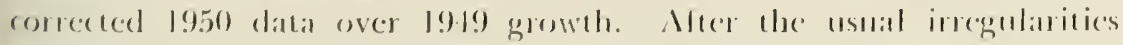

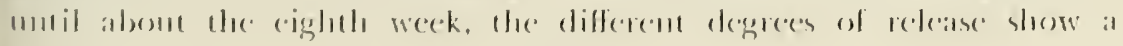


ONE YEAR BASAL AREA GROWTH

IN SOUARE FEET.
INTERMEDIATES

SUMMER RELEASE $12.5-37.4 \%$

2 TREES

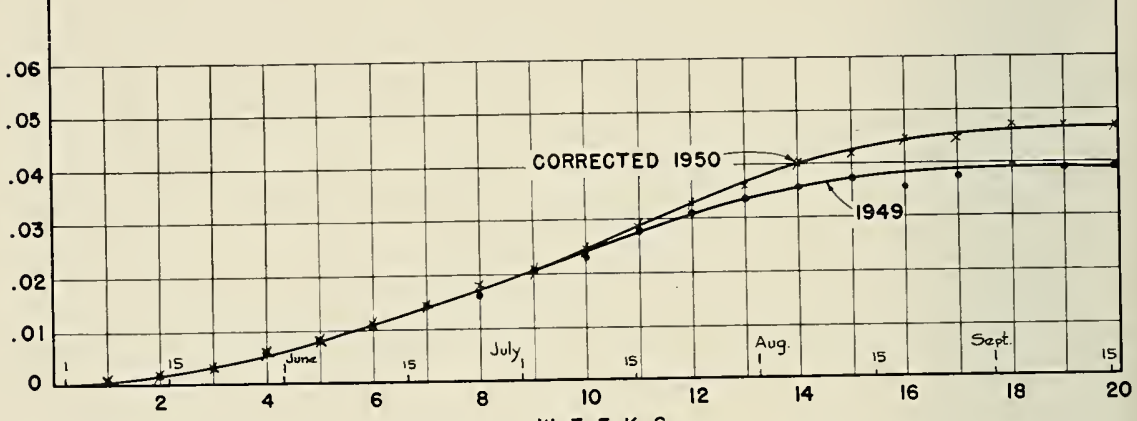

Figure 48. Weekly accumulative basal area growth in 1949 and 1950 of 2 intermediate trees given summer release of $12.5-37.4$ per cent.

ONE YEAR BASAL AREA GROWTH

IN SQUARE FEET.

INTERMEDIATES

SUMMER RELEASE $\quad 37.5-62.4 \%$

(2 TREES)

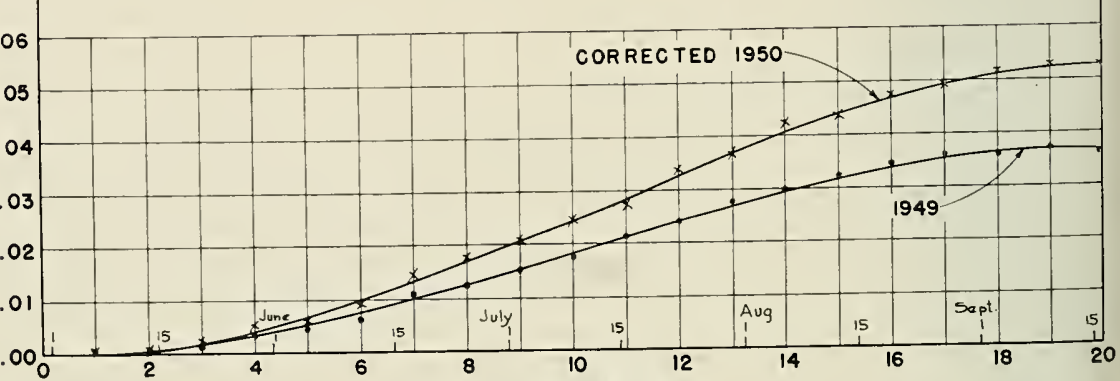

W E EKS

Figure 49. Weekly accumulative basal area growth in 1949 and 1950 of 2 intermediate trees given summer release of $37.5-62.4$ per rent. 
INTERMEDIATES

SUMMER RELEASE $>87.5 \%$

( 2 TREES)

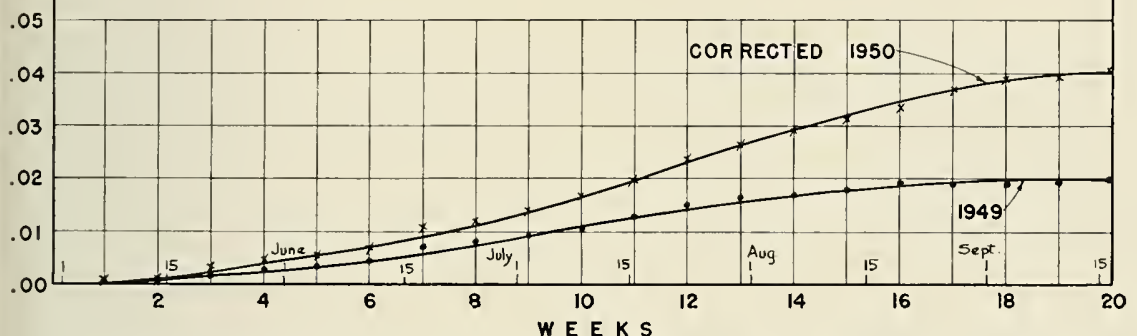

Figure 50. Weekly accumulative area growth in 1949 and 1950 of 2 intermediate trees given summer release of more than 87.5 per cent.

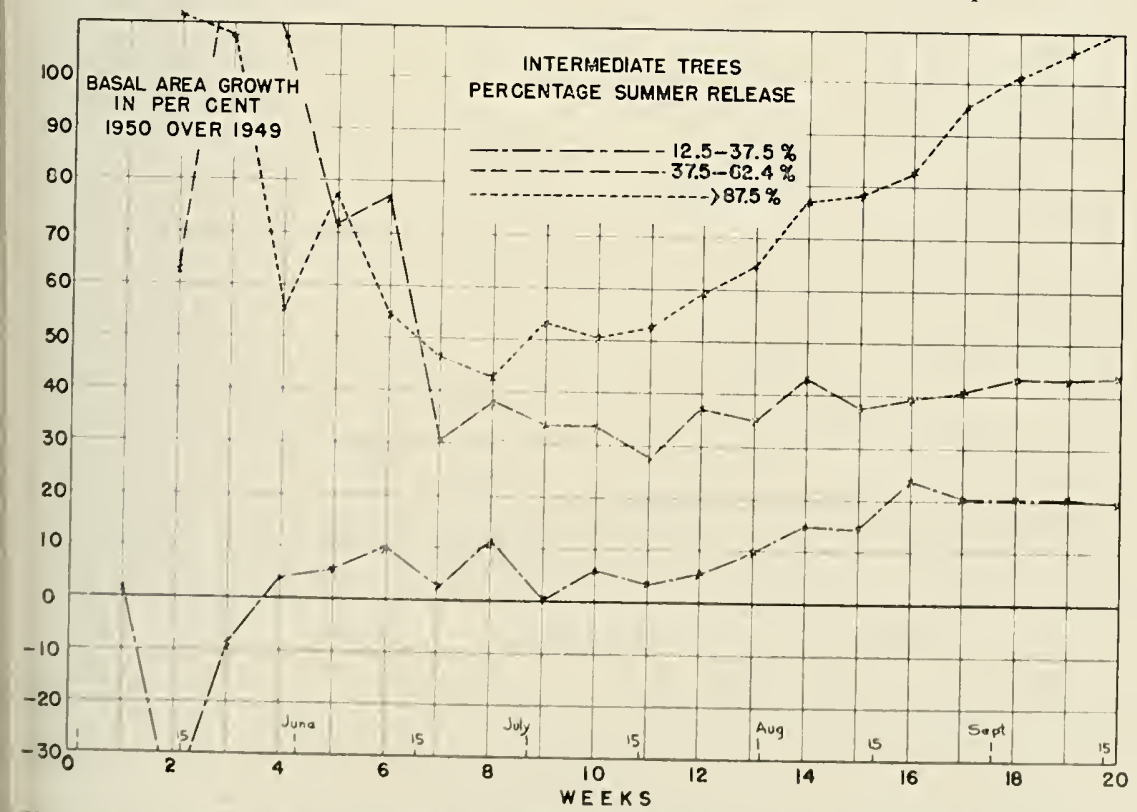

Fisove 51. Perecentage weekly basal area growth in 1949 and 1950 of internediate trees given different percentages of sumuer release. 
growth corresponding to the amount of release the trees have received. The increased growth of these trees is remarkable, since most of their crowns were worn down to a considerable extent. In spite of this, these trees responded extremely well to the release they received. Although a sudden and complete release of worn down intermediate trees cannot be recommended because it often will cause wind breakage, the trees will react favorably to severe releases if no damage occurs to them from other causes.

F. Reaction of Different Crown Classes to the Same Percentagf of Crown Release

In order to investigate the relative reaction of various crown classes to the same percentage of winter release, Figures 52, 53, 54, and 55 were constructed. The general trend in these figures seems to be that for the same percentage release, the lower crown class reacts by growing correspondingly more during the 1950 growing season than does the higher crown class. The only exception is for the release that was less than 12.5 per cent. Here there does not seem to be any difference between the growth increase of dominant and codominant trees. The reason for this may be that the reaction from a small amount of release,

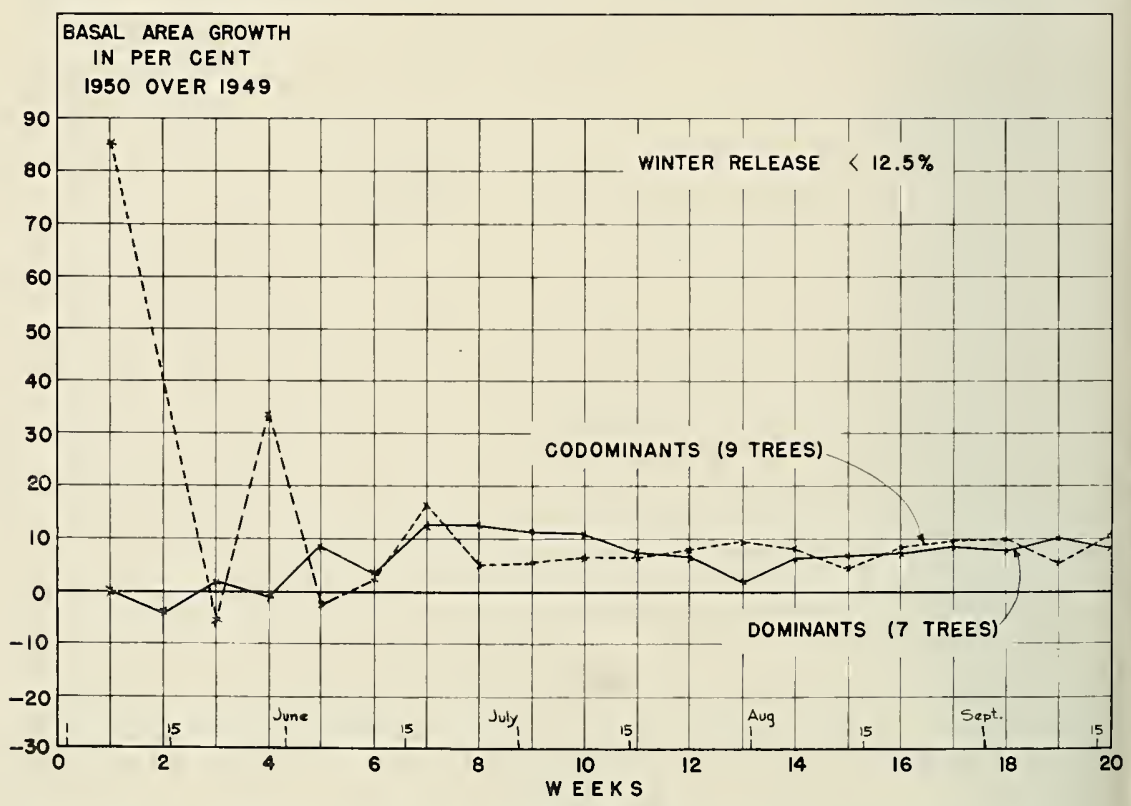

Figure 52. Percentage weekly basal area growth of dominant and codominant trees given winter release of less than 12.5 per cent. 


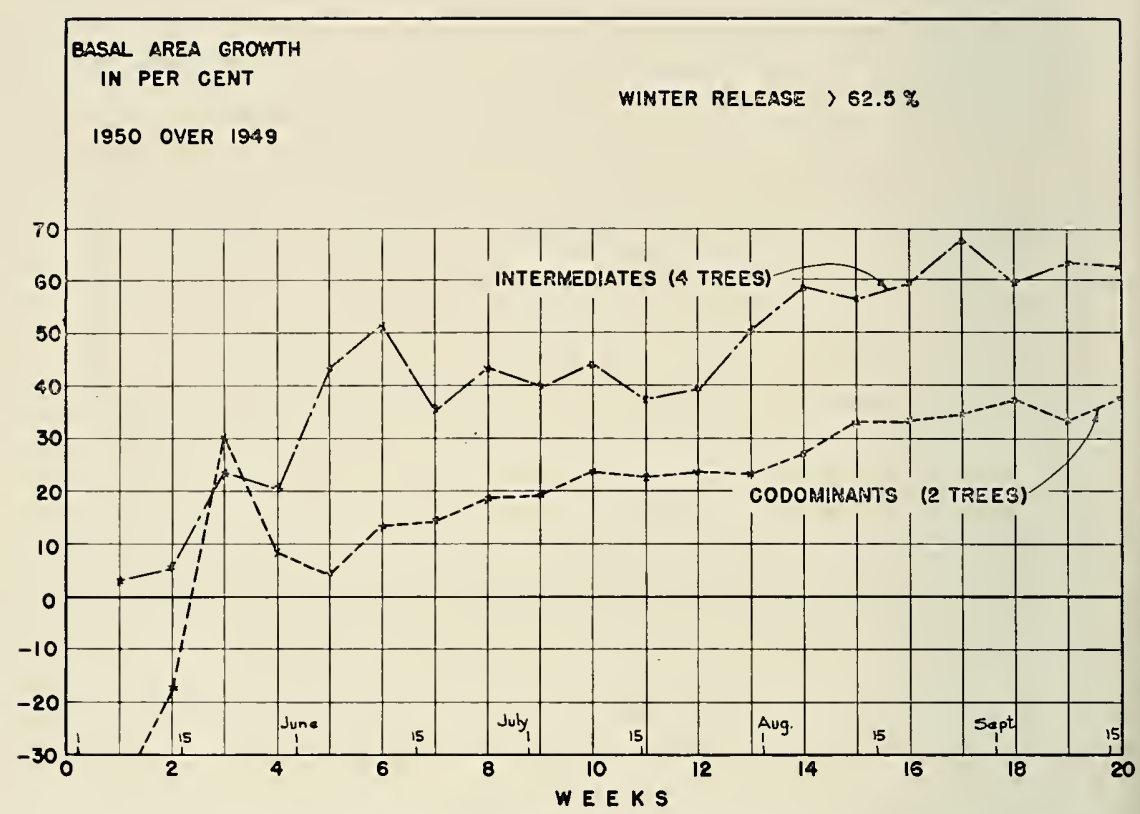

Figure 55. Percentage weekly basal area growth of codominant and intermediate trees given winter release of more than 62.5 per cent.

which in this case for both crown classes was nearly 7 per cent of the crown surfaces, is too small to make much difference.

In the present instance, both crown classes increased only about 10 per cent on basal area growth over the 1949 growth. The additional light to which the crowns are exposed is too small to register a real increase. In this case, where both dominant and codominant trees received a 7 per cent crown release, most of this release took place on the lower part of the crown. On larger trees this part of the crown is rather shallow. Therefore, only relatively few leaves will receive added light. The larger percentage increase in the other figures for codominant over dominant and intermediate over codominant, may take place because the intermediate trees have been growing in comparatively greater partial shade than the codominant trees. Thus, when a certain percentage of the crown is released, the side of the crown will not alone be benefited by the additional light, but the rest of the crown will receive more light as well, since the crowns of intermediate trees are smaller than those of the codominant trees. The same explanation also can be applied to the comparison between the codominant and dominant trees for greater percentage releases. Generally, it may be safe to assume that the lower crown classes have their crowns in deeper 
shade than the higher crown classes. This will mean that the leaves of the lower crown class trees assimilate under a relatively lower light intensity compared to the leaves of the higher crown classes. Therefore, any increase in light intensity for the leaves of the lower crown classes will give greater increase than for the higher crown classes, since the former leaves will assimilate at a rate farther below their maximum capacity than leaves on higher crown class trees.

Figures 56, 57, and 58 show the relationships between the different crown classes that have been exposed to the same percentage summer release. The trend in these figures is the same as occurred for the winter releases of similar percentages. Again there is little difference in the growth increase of dominant and codominant trees that have been exposed to less than 12.5 per cent crown release. For a crown release of 12.5 to 37.4 per cent, the codominant trees show much greater increase on basal area growth than the dominant trees. Likewise, for a summer release of the crowns of 37.5 to 62.4 per cent, the intermediate trees have increased relatively more than the codominant trees.

The fact that the intermediate trees increase relatively more than the codominant trees, and that the codominant trees increase correspondingly more than the dominant trees after the same amount of release, is very encouraging. This will mean that for yellowpoplar

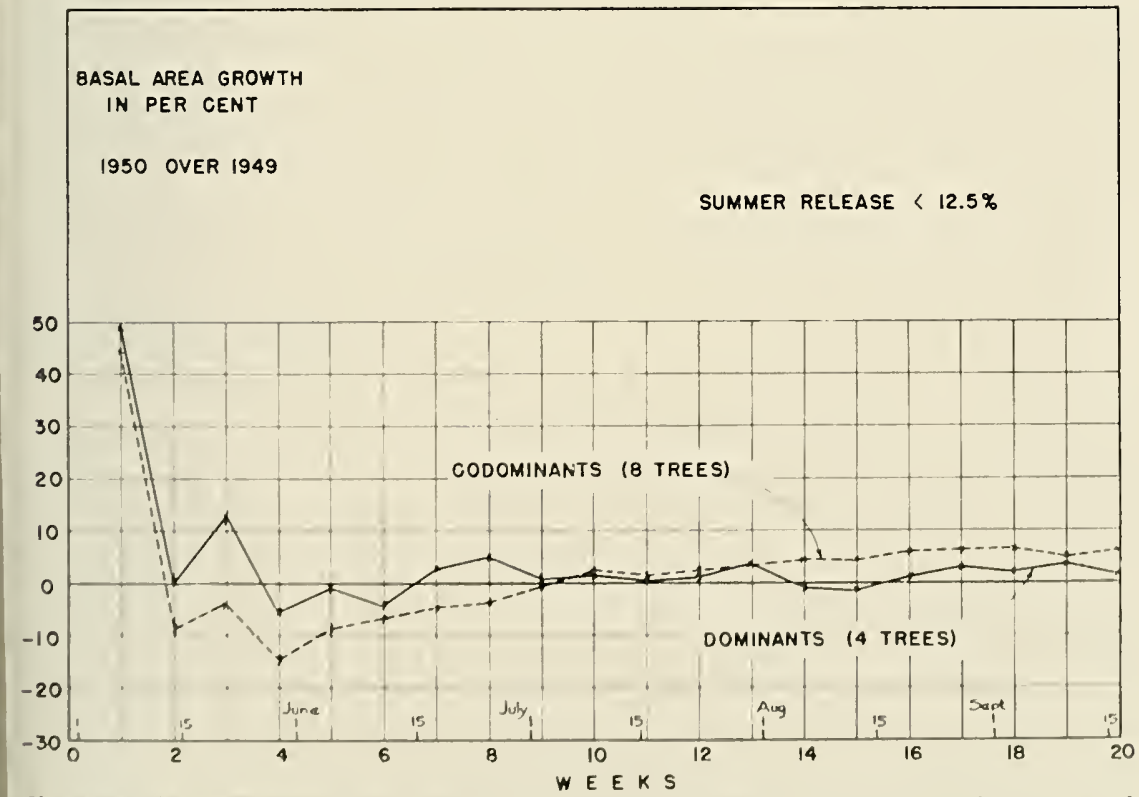

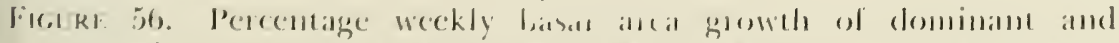

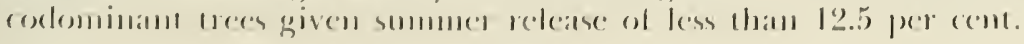


BASAL AREA GROWTH

IN PER CENT

1950 OVER 1949

SUMMER RELEASE $12.5-37.4 \%$

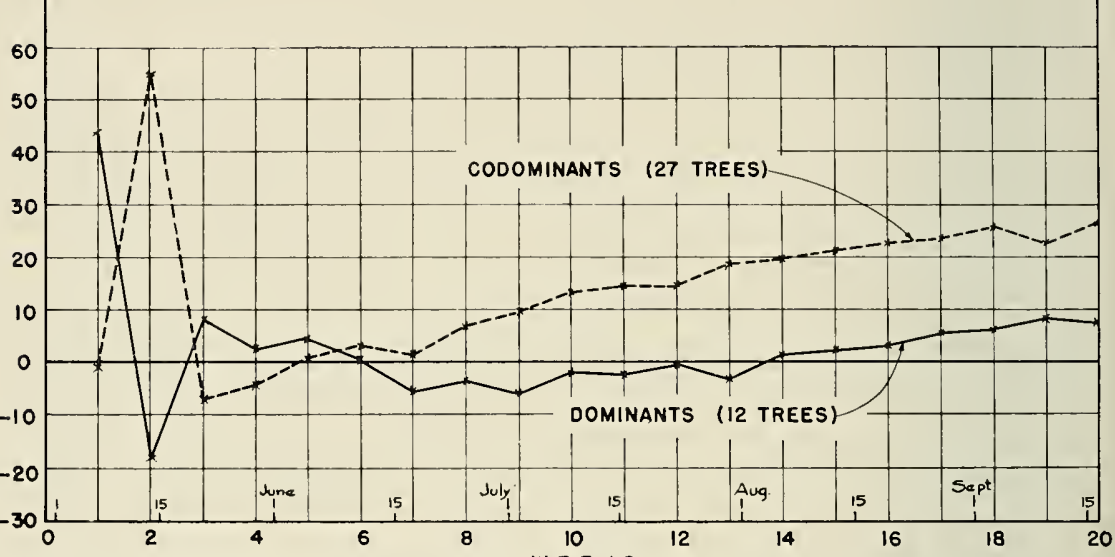

Figure 57. Percentage weekly basal area growth of dominant and codominant trees given sunmer release of 12.5-37.4 per cent.

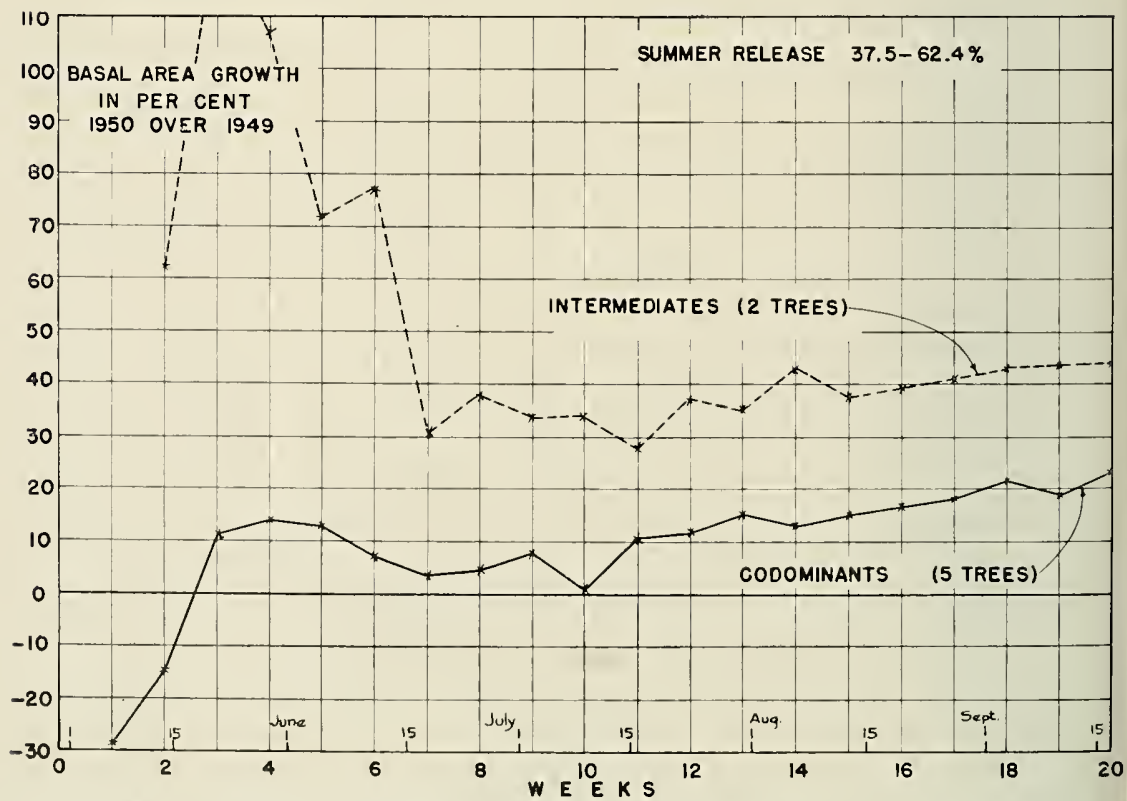

Figure 58. Percentage weekly basal area growth of codominant and intermediate trees given summer release of 37.5-62.4 per cent. 
and perhaps other species, a very favorable reaction will be obtained if in thinnings the lower crown classes are favored. It is possible to get a greater percentage increase, and often it also may be possible to place the growth on stems that will have a greater potential value because of less defects from dead branches and hidden knots. These factors indicate that the Borggreve (2) system of thinning from above may be used successfully in yellowpoplar stands.

In general, the above analyses and discussions show that the more percentage crown release a tree receives, whether it be during the dormant or during the growing season, the more it will increase in growth on the basal area. Furthermore, the graphs show that if the release is made during the domant season, the increased basal area growth will begin early in the growing season. For more complete releases, the increased growth can be recorded as early as the third or fourth week of the growing season. For trees that receive crown releases during the growing season, the reaction will be immediate if these releases are rather complete. For less complete releases, the increased basal area growth will not be recorded until a few weeks after the release takes place. In no case has there been any evidence of shock reaction, although some of the trees received a crown release of more than 87.5 per cent.

It also is interesting to note that for the same percentage release, the lower crown classes will show a greater percentage increase of basal area growth than the higher crown classes. In general, for the same percentage release, a codominant tree will increase more percentagewise in basal growth than a dominant tree during the growing season immediately after the release has been made. In the same way, an intermediate tree will grow more in percentage than a codominant tree.

\section{Statistical Analysis}

For the purpose of determining the validity of the results, $t$-tests were made for each of the classifications between the growth during 1919 before the release was made and the growih during 1950 alter the coons had been released. The 1950 growth was corrected by means of control trees of the same crown classification as the trees that were inalyzed.

Table I show's that the greatest significance is obtancel for the winter releases, siner these will shem langer diflereness on basal areat

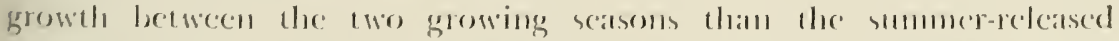
trees. ()wing to the small member of samples in the dominam classi-

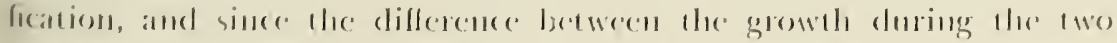
seasoms in this dassification is mot as great as in the codemninant and 


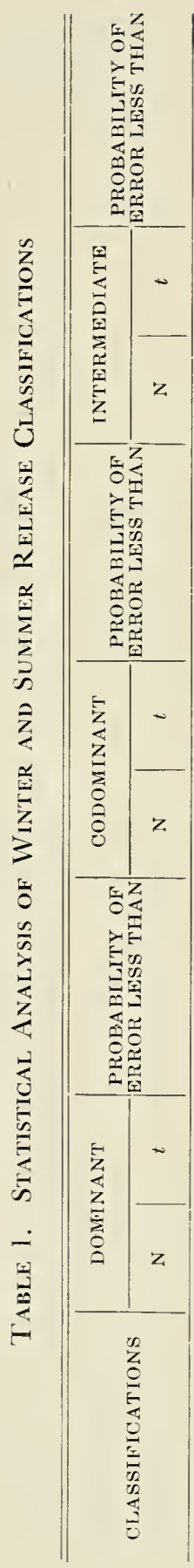

sol | nenen

| ㅇํㄴ $\mid$ 윰

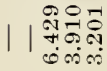

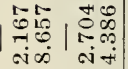

1 | ahe

मीनामी की

|NA |NO

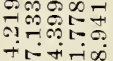

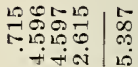

莤

롤

애퓨|न

5.8n

|ำ||1ำ

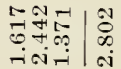

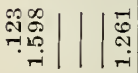

$-10$

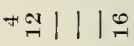

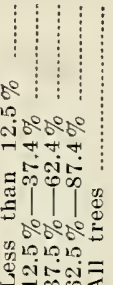

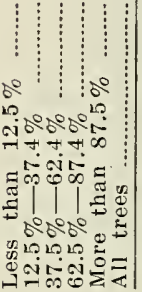


intermediate classifications, the $t$ values do not indicate real differences. In the codominant classification, which was represented by more sample trees, most of the $t$ values are satisfactory. Lack of data in the intermediate classification causes too small values of $t$. It may be assumed, however, that if more sample trees had been available in all classifications, satisfactory values of $t$ could have been obtained in most of the classifications. This is indicated by the $t$ s obtained from the "all trees" classifications, which show a generally higher probability.

\section{Form Changes After Release}

From the foregoing, it is evident that a considerable increase in basal area growth takes place after releases have been made of the sample trees. It might be suggested that most of the changes take place on the lower part of the stem and that this will improve the structural design of the tree, thereby making it more wind resistant. If that were the case, it would mean that the form quotient, the relation of the diameter at half height of the tree divided by diameter breast high, would be smaller. If this happened, the increased rate of basal area growth might not mean an appreciable amount of volume growth.

In order to investigate these relationships, a stem analysis was pe:formed on tree No. 101. This tree was released during the winter () 1941-42 when another yellowpoplar, standing five feet from it, was cut. The crown release was approximately 40 per cent. In 1950, iree No. 101 had the following dimensions:

Diancer breast high $\ldots 16.4 \mathrm{in}$. Crown projection $\ldots .150 \mathrm{sq} . \mathrm{ft}$. Total height ........ $88 \mathrm{ft}$. Ciown surface $\ldots \ldots$ I,I I6.3 sq. ft. Dead length . . . . . . . 40 $40 \mathrm{ft}$ Crown diameter . . . . $23.9 \mathrm{ft}$. Clear length . . ........ $40 \mathrm{ft}$. Crown length ......... $20 \mathrm{ft}$.

The cree did not receive any release after the cutting made in 19.11-12 and was uot in any way released during the experineme, in whirh it was used as a control. Figure 59 shows the form of the part of the stem extending up to 57 feet above the ground. The curves indicated are the dimcusions inside bark in 1932, 1911, and 1950, showing the form of the tree 9 years prior to the release and 9 years after the release. The graphs show that no appreciable chathge in form has laken plare doming the last 18 years. The lollowing ligures will show the lomm in more: detail: 
D.P.H. inside bark . . . . . . . . . . . 14.66

11.88

9.54

Diameter 17 feet above ground . . . . . . . . 13.08

Diameter 44 feet above ground 10.10

Diameter 17 feet

\section{D.B.H.}

Diameter 44 feet

\section{D.B.H.}

This indicates that although there has been a slight decline of the proportion between the inside diameter at the top of the first 16 -foot $\log$ divided by d.b.h.--the so-called Girard Form Factor-there has been an increase in the regular form quotient. This last one is based on the diameter inside bark at half the height of the tree in proportion to the diameter breast high. The conclusions from these calculations must be that if any change in form has taken place, it has been towards a form that is closer to the cylinder compared to what it was before thinning.

In the left part of Figure 59 is shown the total diameter growth in inches for the 9-year period before release and the 9-year period after release. It is evident that the total diameter growth at various

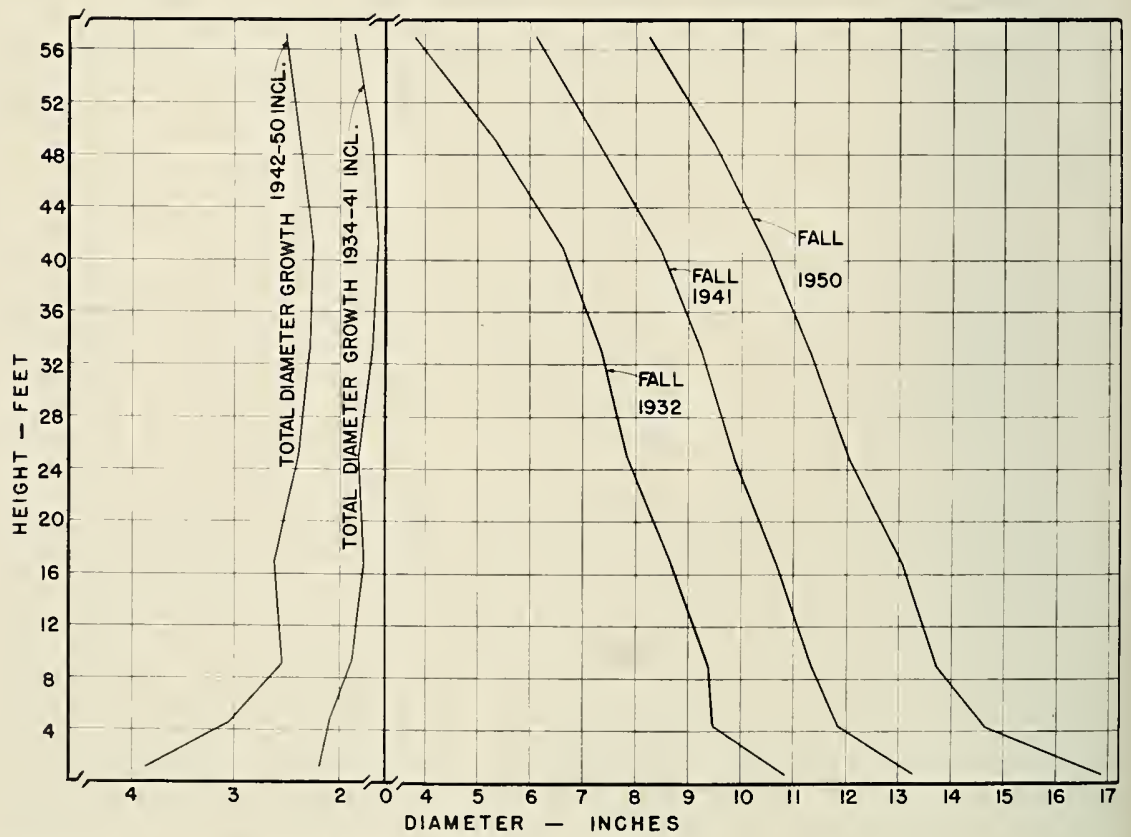

Figure 59. Stem analysis of Tree No. 101. 
points of the stem has been much greater cluring the period after release than in the period before release. For some reason, the diameter growth I foot above ground has increased proportionally more than any of the other diameters. Otherwise, the increase has been rather even throughout the stem, with a percentage increase for the last 9 years over the 9 years previous to the release varying from 29.9 at 25 feet above the ground to a maximum of 47.5 per cent at 17 feet above the ground. The percentage increase at breast height was 43.8, considerably less than the maximum increase.

It is realized that an analysis of only one tree cannot give conclusive results, but since no other trees were available which had received a release several years before, it was not possible to supplement the foregoing analysis with more data. Based on the measurements listed above, however, there are indications that the diameter at various points of the stem will increase at about the same rate as will the diameter at breast height. If this be true, and there are no reasons to believe differently, the measurements given for basal area growth also will be indicative of volume growth.

It is interesting to note in Figure 60, which shows the basal area growth of the same tree discussed above, that there is an increase on the entire tree during the first growing season immediately after

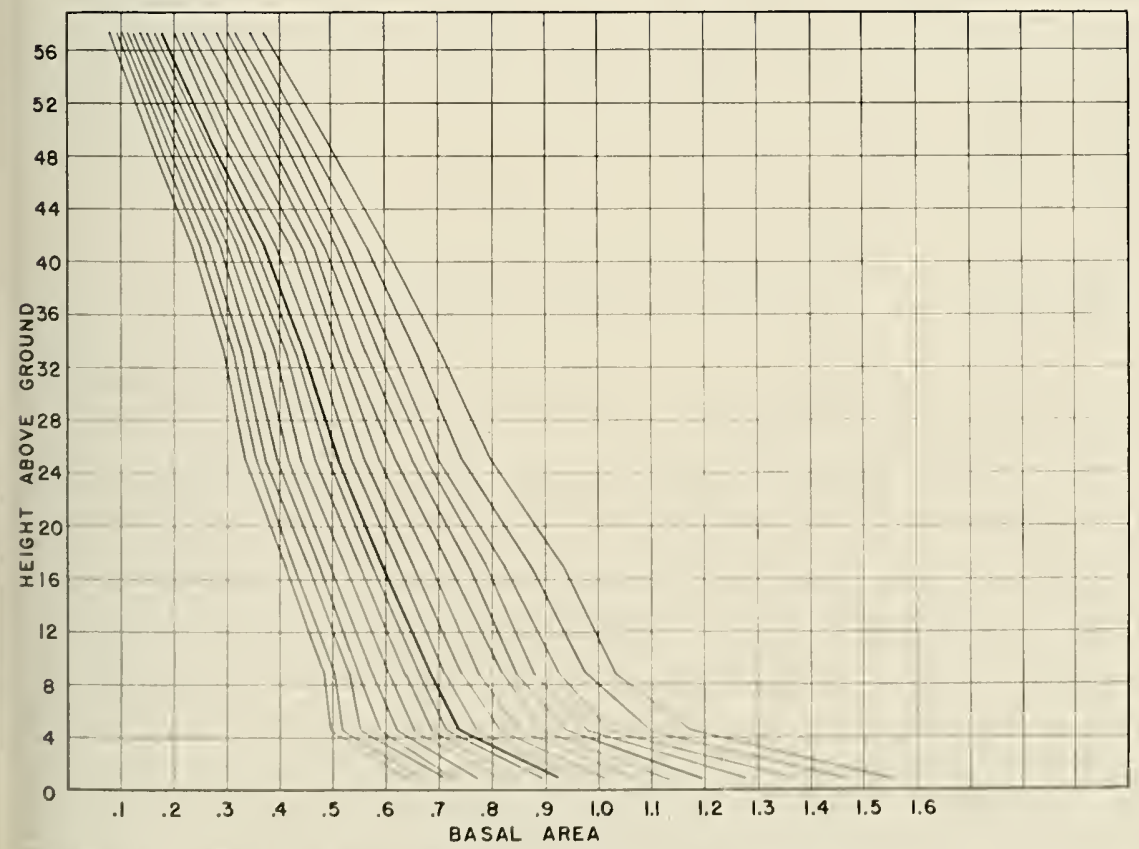

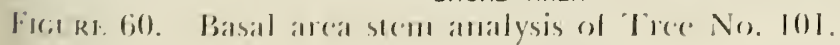


release. This basal area increase gets progressively greater as the tree grows. The explanation for this may be found in a statement on assimilation by Heinicke and Childers (12): "Much of the leaf surface, probably more than 90 per cent of the total, is functioning at a very low rate on many days during the season." This will mean that immediately after a tree is released, additional light will be available to many of the leaves. The additional light will enable the leaves to produce at a greater rate than before. During the following years the crown will have opportunity to expand because of the open space available after some of the conpetition for light has been lessened by cutting a neighboring tree. With the expansion of the crown, more leaf surface will be available for increased production. This shows up in the increasing rate of growth as seen in Figure 60.

The varying amount of assimilation of the individual leaves, which is caused by differences in available light, may be the reason for the spread of the individual data in the relationship between basal area growth and crown surface shown in Figure 11. Although a rather high correlation index was obtained for this relationship because the trees included had not been released during the last ten years, differences in light intensities for different parts of the crown may have caused much less assimilation on the more shaded trees compared to the more dominant trees with the same crown surface. Although, in general, crown surface is a good indicator of basal area growth, crown surface may show a considerable spread of the data if the measurements had been taken in a stand in which some trees had been released more than others.

\section{Differences in Radial Growth on the Same Tree}

When measuring radii at breast high on tree No. 101 to obtain data for the stem analysis, it was noticed that these varied considerably. Further investigation revealed that on some trees with several dendrometer stations, the difference in growth in some cases was as great as 50 per cent at breast height.

Since it is sometimes believed that crown development and radial growth are related in such a way that the side of the stem that is under the largest crown development grows faster, measurements from dendrometer stations for the growing season of 1949 were compared with the crown radius directly above the station on trees that had several dendrometer stations. The radial growth for 1949 from these stations was plotted over the crown radius directly above the station, but no significant correlation was found. This shows that for the sample 
trees investigated, the uneven crown development does not have any influence on the radial growth of the tree.

Another hypothesis that has been mentioned is that trees grow faster on the northern side because of the presence of more moisture, which supposedly should create greater radial growth. To check this possibility, the radial growth for 1949 was investigated on trees that had four micrometer stations placed in the cardinal directions of north, east, south, and west. The basal area growth for 1949 for each of the directional dendrometer stations was plotted over diameter breast high measured with diameter tape. The data showed no relationship and the averages of the values for radial growth for 1949 for the different directions were about the same. This indicated that no radial growth related to cardinal compass directions grew faster than any other one.

Finally, the 1949 basal area growth was calculated on the basis of one radius for each tree with several stations in such a way that the stations were grouped in relation to whether or not they were located over the largest root extending from the tree, the second largest root, or no root. The basal area growth was related to the crown surface. Figure 61 shows the three curves resulting from this investigation. The

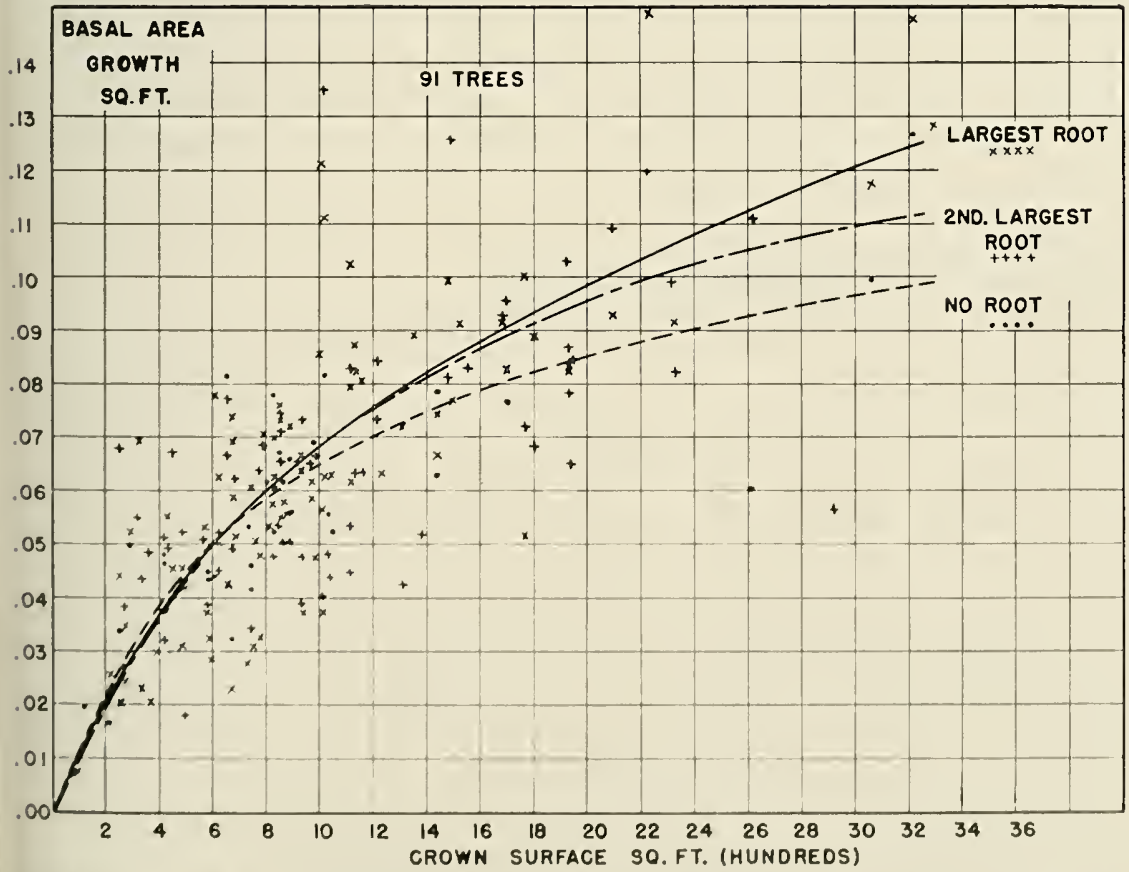

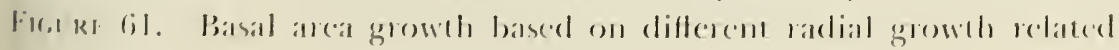
to tree roots. 
curve for basal area growth, deternined by radial growth over the largest root, has a correlation index of .893. The curve for basal area growth over the second largest root has a correlation index of .592, whereas the curve for basal area growth over no root has a correlation index of .803 . Up to 800 square feet of crown surface there is no difference between the three curves. For the larger crown surfaces, however, there are considerable differences between the three curves.

For the purpose of determining growth of stands by taking increment borings from sample trees, it is of importance to take these in the same relative position as roots that extend out from the trees. Otherwise, a considerable variation may be included in such measurements. This would establish considerable inaccuracies in prediction of growth of stands.

For the purpose of detemining how far up the stem this influence of the roots extends, a stem analysis was made of tree No. 101, which was cut down after the 1950 growing season. By plotting the radii over the largest root, the second largest root, and over a place from where no roots extended, the measurements at breast height showed that during the last 9 years the radius above the largest root had grown 1.7 inches, and the radius over no root had grown 1.4 inches. At a point 9 fect above the ground, the effect of the roots had diminished. At that point the radial growth above No. 1 root for the last nine years was 1.25 inches, over No. 2 root 1.3 inches, and above no root 1.2 inches. Farther up the tree no relationship was found between the roots and radial growth.

\section{Light Intensity and Root? Competition}

For the purpose of perhaps throwing some light on the question of which factor or factors are causing the increased growth after the trees are released, a separate experiment was established. The thought cccurred that if instead of cutting the neighboring trees, these were only bent away from the sample tree, this tree would receive as much light as if the surrounding trees had been cut. On the other hand, if there was any interference from root competition, this would still be present. Unfortunately, the yellowpoplar that were used in the experiment were so large that it was impossible to bend them away from the neighboring trees. To get a little information on this problem, however, such an experiment was established in a hybrid poplar plantation.

These hybrid poplar were planted as cuttings in 1941, but had been cut down to obtain cuttings for planting stock. In 1943 they 
were allowed to grow up. At the time of the experiment they had a diameter of between 4 and 5 inches and a height of 25 feet. Since the plantation is very small, it was possible to establish only 2 trees of each category -2 for control, 2 to be released by thinning, and 2 by bending the neighboring trees. One dendrometer station was estab. lished on each of the trees. Measurements were taken throughout the 1949 growing season without disturbing the growing conditions of the trees. During the dormant season of 1949 and 1950, all trees that were interfering with the crown development of 2 of the trees were cut. For 2 other trees the interfering ones were bent away and held in that position by ropes during the entire growing season of 1959 . The 2 control trees were not disturbed. The selection of the individual tree for any of these classifications was made arbitrarily.

When the plantation was established by cuttings, it was done on a 3 by 3 foot spacing. After it was allowed to grow in 1943, it became very crowded and was released to a 6 by 6 foot spacing in 1946. Since then no more cutting was made in the stand up to the time of the experiment. Therefore, the trees were quite crowded and exerted considerable interference on each other. Not until the results of the control trees became available, however, was it realized that the stand was actually stagnating. As can be seen in the lower part of Figure 62,

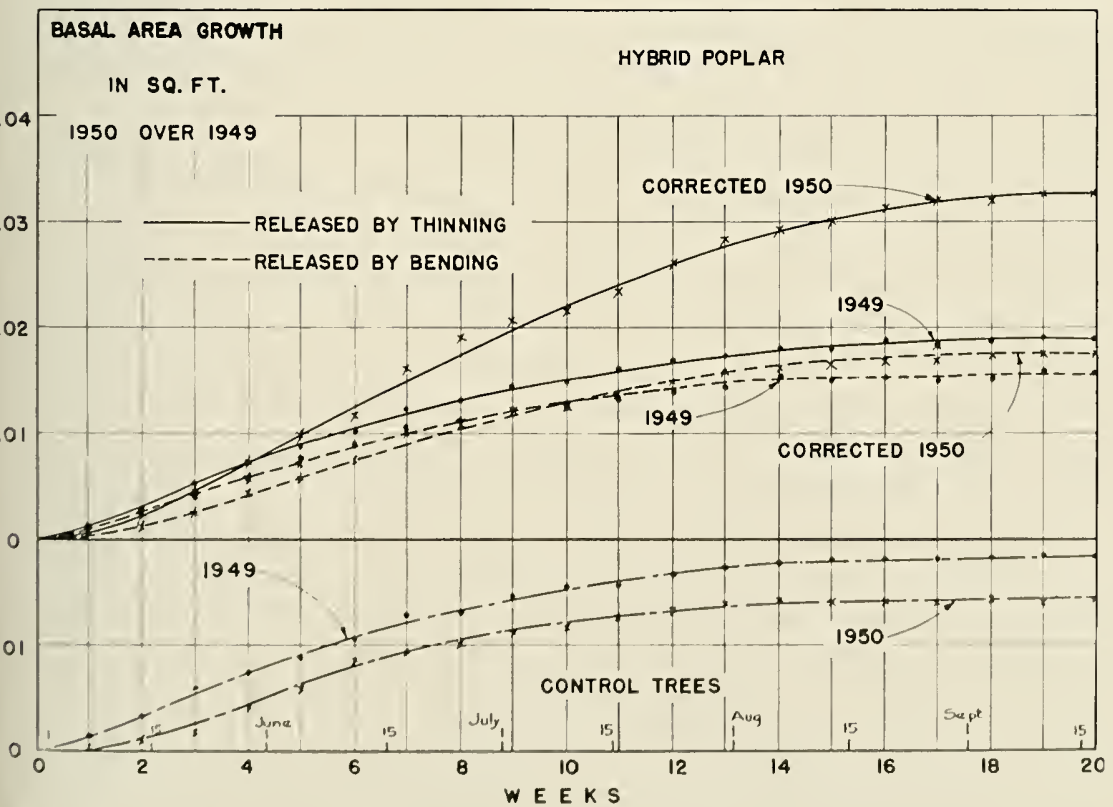

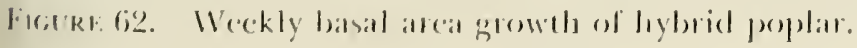


these trees have grown considerably less on the basal area during 1950 , compared to the growth during 1949, even though the yellowpoplar that were growing in close proximity to the hybrid poplar showed considerably greater growth on the control trees during 1950 than in 1949. The upper part of Figure 62 shows the comparison between the corrected growth of 1950 and the growth of 1949 . The growth of 1950 was corrected on the basis of difference in growth of the control trees during the two growing seasons, just as was done for the yellowpoplar experiment. In Figures 62 and 63 , it can be seen that the trees that were released by cutting the neighboring trees have increased considerably after release, whereas those which were rcleased by bending away neighboring trees have increased only slightly. Although the result from this experiment by no means can be termed conclusive, owing to the small number of sample trees, it may show some trend that can be interpreted in this way: root competition shows considerable influence where the trees grow close together. In such places, even if the soil is moist and well-drained, the limiting factor seems to be root competition rather than crown interference.

\section{Profitable Tree Forms}

In order to conduct intensive silviculture management, it is necessary to have an intimate knowledge of the growth and reactions of the individual tree. During the last 150 years, volumes have been written about forest stands, their volume per unit, the average diameter, and their reproduction. Little, however, has been studied about the single tree, the proportion of its crown to the total height, the number of clear $\operatorname{logs}$ it should have in order to produce the best value in the shortest time, its reaction to release of varying degree, and the compound interest rate with which it grows during the stages of its development. In recent years an interest in these matters has occurred through the work of Biolley (1), Mundt (10), Muus (20), and others. It is strange, however, that this interest has not taken form in writing before, since as early as 1818 Reventlow (25) wrote about oak and beech in Demmark as follows: "It must be assumed that the rotation of oak should be determined by the time it takes to produce heavy timbers providing that these will yield favorable prices. The owner will then be fully compensated for having the trees beyond the time when the volume increment drops below 4 per cent interest compared to the volume of the tree. However, for beech the main object will be to grow fire wood. Therefore, the rotation should be determined by the time at which the annual growth be less profitable than the interest of the capital vested in the tree." 


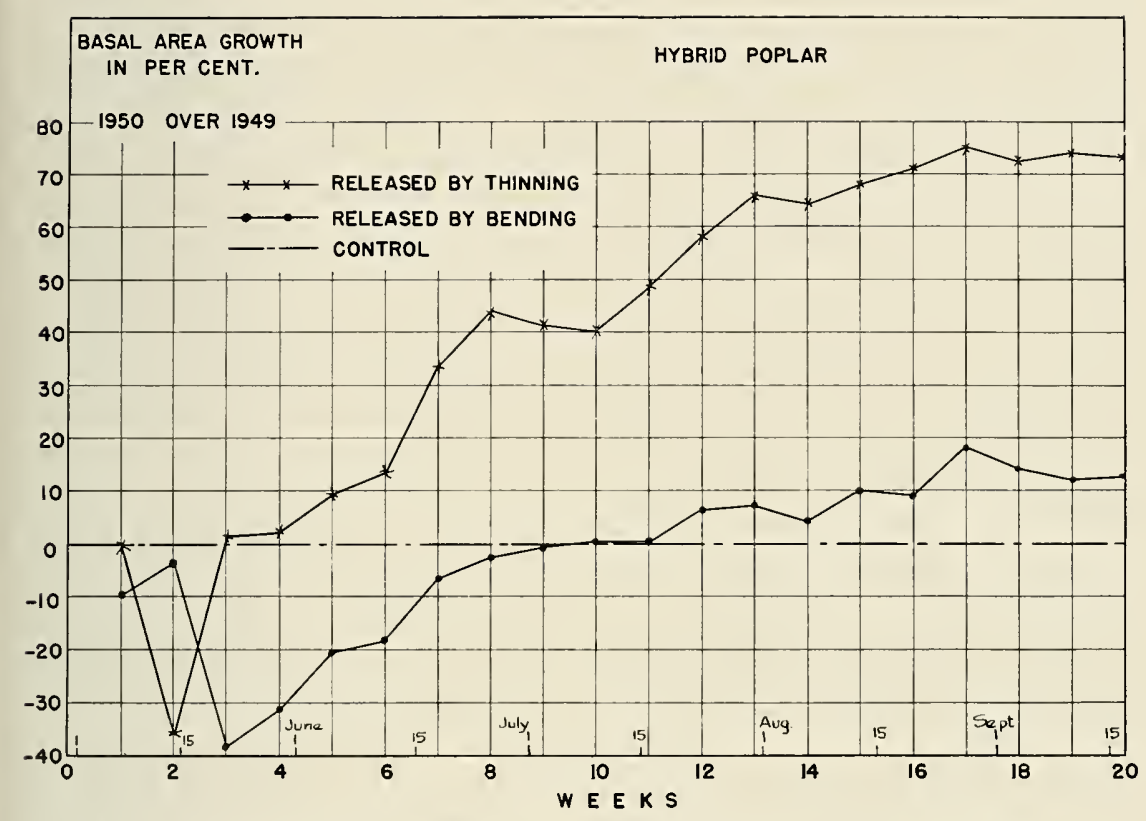

Figure 63. Percentage weekly basal area growth of hybrid poplar.

This definition and direction for silvicultural management is as modern as if it were written today. In order to conduct profitable silvicultural management, the compartments and area units cannot yicld a profit unless the individual tree yields an interest rate equal to the interest that could be obtained on other capital investments. Not until cach unit yiclds a profit will the whole forest produce its maximum interest rate on the invested capital.

In a former publication (14), various relationships for yellowpoplar were presented, such as total height and age, total height and crown length, total height and crown diancter, total height and diameter breast height, and total height and clear length. Besides these, ton years basal area growth for the individual tree was related to crown length and crown diameter. Finally, a table showing the compound interest rate of periodic growth for various dianneters breast high was constructed from the lumber grades sawed from logs of sample trees whereby the value of the individual tree was obtained. The total height, rather than age, was used as an entry to all curvilinear relationships for the dimensional measurements of the tree, since the age is not as indicative as total height when the general development of a tree is being discussed. Furthermore, using total height as a basis will more or less do away with the necessity of taking into consideration 
different site indices for the growing places of yellowpoplar. From a study by M $\phi$ ller (21), showing the growth of beech on five different site indices, it can be seen that for the same total he ght, the diameter breast high, basal area, and volume are almost the same for each site index class.

Since it is possible to create the most profitable forms of yellowpoplar by releasing their crowns and since, based on the present findings, these releases can be made by relatively few cuttings effecting more or iess complete releases without creating unfavorable growth reactions, it is considered of interest to investigate how the individual tree should be formed in order to produce the highest possible interest rate throughout its life. In the Appalachian region the most favorable diameter breast high for logging purposes is considered to be between 24 and 26 inches. This is due to the terrain and the capacity of the average saw mill. Such trees will produce a large amount of high-grade lumber. Also, their size will be more favorable in logging costs per thousand board feet, compared to both smaller and larger dimensions. Furthermore, to produce these dimensions profitably, the individual tree should maintain a compound interest rate throughout its life of more than 6 per cent. To investigate the radial growth of a 24-inch tree growing 6 per cent compound interest per year, Table 2 from an earlier publication (14) is used.

In Table 2 it can be seen that if a 24 -inch tree is to produce 6 per cent compound interest, it will have to have a radial growth of about 1.8 inches cluring the last ten years. From the charts available in Profitable Tree Forms of Yellowpoplar (14), it will be found that to have such a growth the tree will have to have a crown length of close to 70 feet, which for a total height of 100 feet will leave two 16 -foot logs in clear length. From the curve giving the relationship between crown length and crown diameter, the corresponding crown diameter was found. If a 100 -foot tree is to have 33 feet of clear length, it is necessary to maintain live crown above 33 feet from the time this clear length is established. From the curve showing the relationship between total height and crown length, it will be seen that at a total height of 60 feet the crown length is about 28 leet. From then on no more clear or dead length should be established. Therefore, the relationship between total height and crown length will increase from this time on. This is shown in Figure 64. Through adequate thinnings such a crown length can be developed.

By means of the relationship between crown length and basal area growth during the last 10 years, it is now possible to construct Table 3. Starting with a tree 40 feet tall that, according to the relationship between total height and d.b.h., has a diameter of 7 inches 

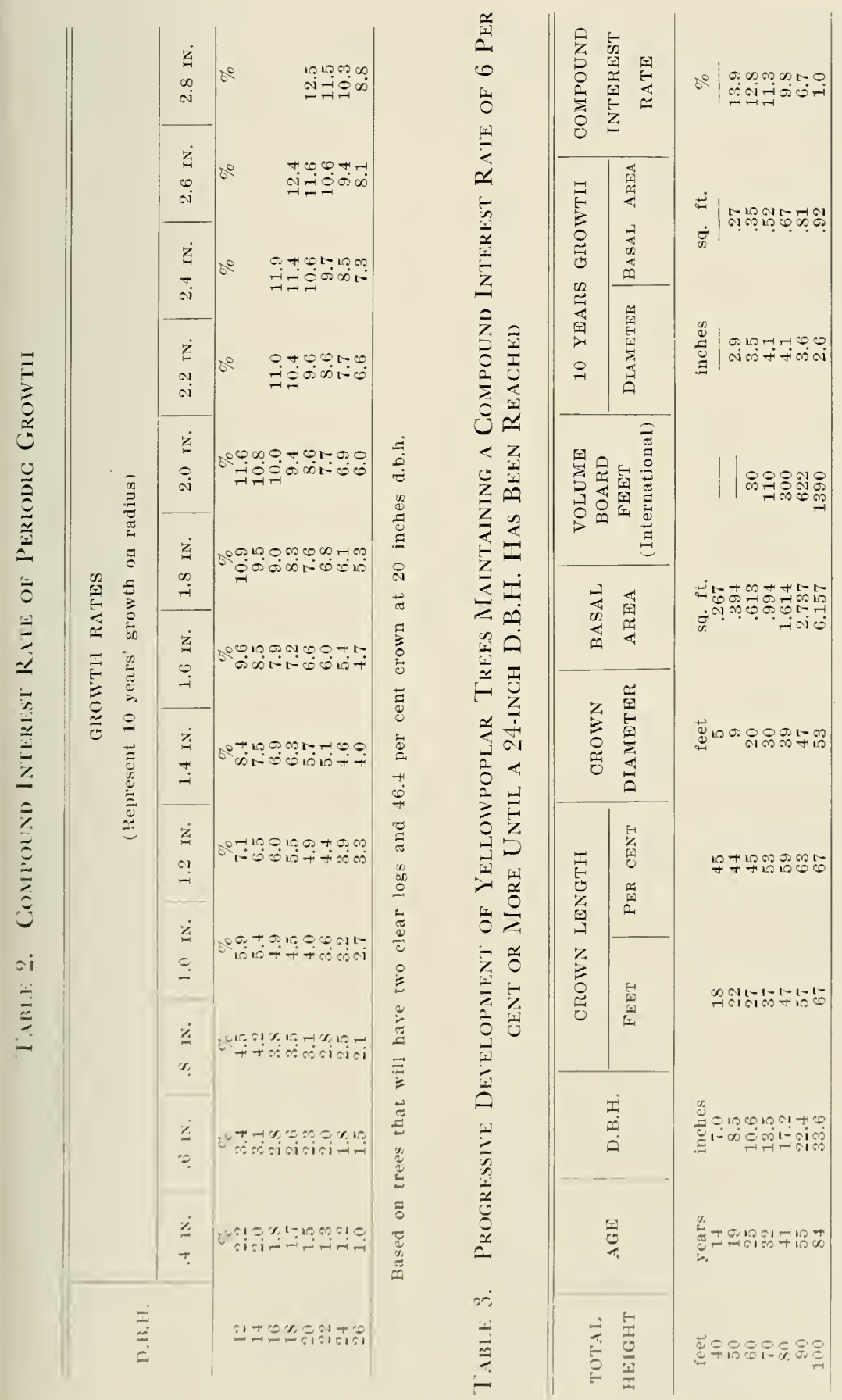


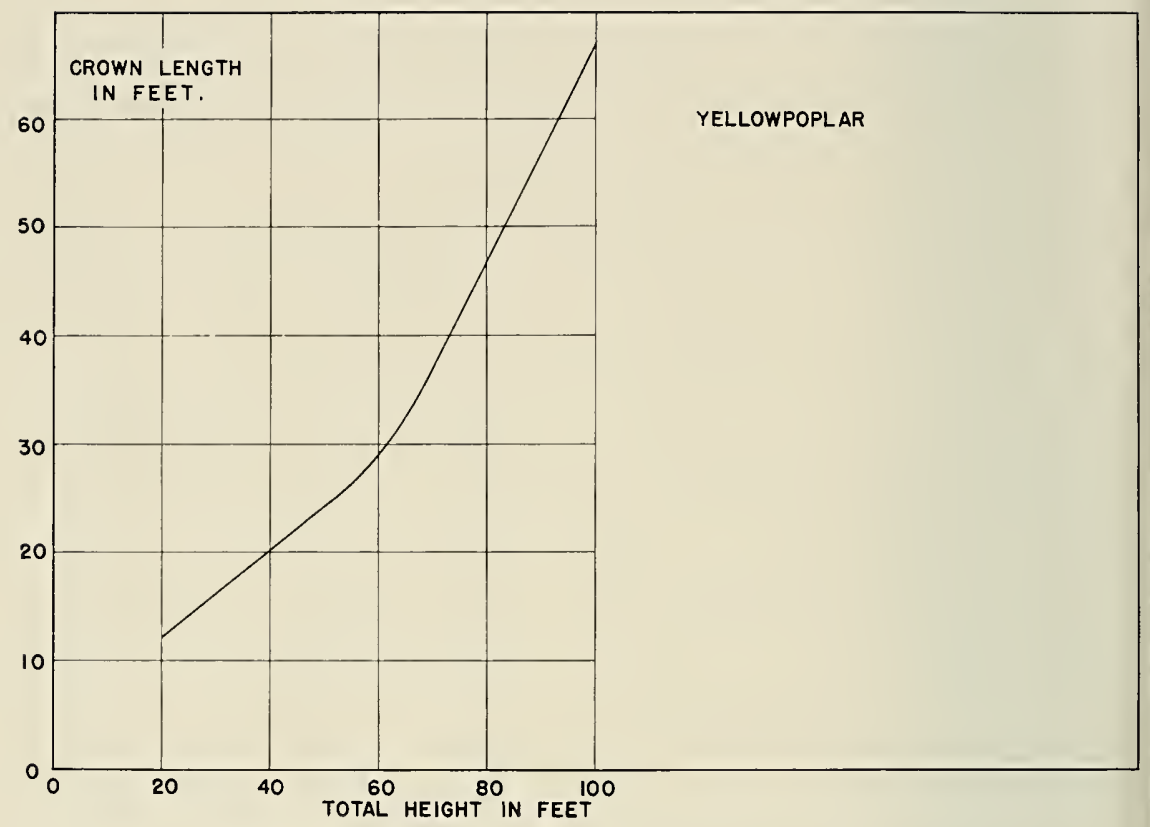

Figure 64. Relationship between total height and crown length.

and which, according to the total height and age curve, is 14 years old, the basal area growth for 10 years is added to this diameter. This gives the d.b.h. at 24 years. From this, the d.b.h. for a tree 50 feet tall and 19 years old is found to be 8.5 inches. Again, the basal area growth for 10 years, based on the corresponding crown length, is added to the diameter. Through this the d.b.h. for a tree 60 feet tall and 25 years old is found. The calculations for the total heights in Table 3 are made in similar ways.

From the results in Table 3, Figures 65 and 66 have been constructed. They show the development of the single tree for various total heights. It will be seen that with increasing age and d.b.h, there is a corresponding decrease in the compound interest rate. At a total height of 92 leet, the d.b.h is about 24 inches and the compound interest rate is 6 per cent. These curves may serve as a guide for the forest manager. By taking a few simple measurements, he will know if the individual trees need more space in order to conform with the rates of development shown in these figures. If the development of the individual trees can be made according to these figures, he will know that each tree is returning an adequate compound interest rate on the capital in form of value invested in the individual tree. 


\section{General Gonclusions}

As was mentioned previously, many European foresters recommend light but frequent thinnings. In Denmark, where the forests are managed intensively, foresters advocate that seldom should more than 12 to 15 per cent of the volume be removed during any thinning. Normally such thinnings are made in the younger stands, with three to four-year intervals. In the older stands the intervals may be five to seven years. Two main reasons are given for these light thinnings: (1) if heavier cuttings were made, the trees would receive a shock and stagnate for a few years; and (2) the soil may deteriorate and a heavy matting of grass will cover the ground. This latter occurrence is mainly due to the rather heavy and poorly drained soils.

In this country, light and frequent thinnings will be profitable only where the markets for small-dimensioned materials are exceptional and where the forest areas are exceedingly accessible. Generally, light thinnings with three-year or four-year intervals, which yield little volume per acre, will not make profitable operations. The alternative has been for foresters to interest owners in making periodic thinnings with longer intervals. Such cuttings may not be ideal in many ways. The most serious drawback to such infrequent thinnings is that the remaining trees will have to be liberated to a considerable extent if they are not to crowd each other before the next thinning. A crowded position before the next thinning would cause the lower branches to die. This would increase the dead length and cut down on basal area growth. The soil deteriorating effect of heavier cuttings does not seem to be a serious problem in this country. Herbaceous vegetation may increase after a heavy thinning, but a heavy grass sod is seldom established in the forest. After the stand closes up, this vegetation will again subside and not cause any ill effect on the soil condition.

As a general directive to silvicultural management of hardwood stands, particularly yellowpoplar stands, it seems reasonable to believe, according to the findings reported above, that heavy thinnings will not have any retarding effect on this species but, on the contrary, cause an increasing amount of growth on basal area on individual stems corresponding to the release. Therefore, it is possible to make thinnings that will remove between 30 and 40 per cent of the volume in each cutting. Such thinnings will increase the basal area growth on the remaining trees and considerably shorten the rotation age of the indi. vidual tree. Furthermore, such thinnings not only will increase the growth on the remaining trees, but also will develop wood with higher specific gravity and more strength, as reported by Erickson (9). Thinning: 
of this severity might have to be done only at eight-year to ten-year intervals to prevent the crowns of the remaining trees from interfering too seriously with each other and thereby retard the dianeter growth. Such thinnings are likely to be made in many parts of this country, because by cutting out more volume than would be done through more conservative methods, they will have a better chance to produce a profit from each of the cuttings wherever there are markets for smalldimensioned materials such as pulpwood, mine props, and fire wood.

\section{Summary}

Since the amount of material removed in each thiming is closely related to the economics of such an operation, and since foresters marking for thinning are constantly confronted with the question of how much crop trees should be released, this experiment was established to study the reaction of various degrees of release on individual remaining trees.

A micro-dendrometer was used to measure weekly radial growth on 193 sample trees of yellowpoplar during the 1949 and 1950 growing seasons. During the dormant season, the crowns of 68 trees were released from less than 12.5 per cent to more than 75 per rent. A sinilar release was made for 67 trees during the 1950 growing season after no further change took place in the rell structure of either light or shade leaves. Fifty-one trees were maintained as controls.

Through these investigations, it was found that yellowpoplar reacts favorable to release of the crown, varying from 12.5 per cent to more than 75 per cent, made both during the domant and the growing season.

The reaction to release during the dormant season was noticcable by the fifth or sixth week of the growing season. The increase in basil area growth corresponded to the percentage of the released crown surface.

The sample trees were divided into the onventional crown classes of (omminant, coxlominant, and intemediate. No retarding eflect of the sudeden and dastic release of the crown was lomel for any of the (rown classes.

for the sance perentage crown release, it was found that intermediate trees would shom a greater percentage increase in batsal area growth than coelominant trees. Cisclominam trees in torn would increase more, on a pereentige basis, on basal area growth than dominam trees receiving the sance perecentage relcase of the rowns.

A stem antalysis was made of a tree released ! yeats ago. A comparison of the fomm of the tree 9 years betore refease, at the time 
of release, and 9 years after release, indicated that the form factor had improved. This indicates that the increased basal area growth also may express an increase in volume.

Using analyses of the results obtained, together with the findings given in a former publication (14), recommendations have been made for growing the individual tree in such a way that it will maintain a compound interest rate of 6 per cent until it has reached a d.b.h. of 24 inches. A table has been constructed giving dimensional figures for the tree during its different stages until it reaches maturity.

The possibility of favorable response to drastic releases of crown surfaces makes it possible to practice intensive management on young stands that are not able to produce enough volume from light thinnings to make such operations profitable. 


\section{Literature Cited}

I. Biolley, H. E., L'Amenagement des Forets par la Methode experimentale et specialament la Methode du Controle. Paris, 1920

2. Borggreve, Bernard, Die Holzzuch. Berlin, 1891.

3. Bornebusch, C. H., "Udhugningens Betydning for B $\phi$ geskovens Udformning og Cen: Vaerditilvacker." Dank Skovforenings Tidskrift, 1940, pp. 261-320.

4. Brown, C. T., Rose, Richard C., and Spurr, Stephen H., "The Dial Gauge Dendrometer as a Tool in Silvicultural Rescarch." Journal of Forestry, Vol. 45 (February, 1947), pp. 102-104.

5. Busse, W., "Baumkrone und Schaltzuwachs" Forstwissenschaftliches Centralblatt, Vol. 52 (1930), pp. 310-318.

6. Clements, Frederic Edward, Plant Plisiology and Erology. New York, Henry Holt and Company, 1907.

7. Daubenmire, R. F., "In Improved Precision Dend:ometer." Ecology, Vol. 26 (1945), pp. 97-98.

8. Eames, J. Arthur, and MacDaniels, Lawrence H., An Introduction to Plant Anatomy. New York, NcGraw-Hill Book Company, 1925.

9. Erickson, Harvey D., "Relation of Specific Gravity to Shrinkage and of These Factors to Growth in Yellowpoplar." Joumal of Agricultural Research, Vol. 78 (1949), pp. $101-127$.

10. Gr $\phi$ n, A. Howard, "K. H. Mundt, In Memorium." Dansk Skovforenings Tids. skrift, 1945, PP. 529-554.

11. Heck, K., "Beitrage zur forstliche Zuwachskunde." Forstwissenschaftliches Centralblatt, Voi. 68 (1924) pp. 26-40, 67-77, 145-156, $211-219$.

12. Heinicke, A. J., and Childers, N. F., "The Daily Rate of Photosynthesis, During the Growing Season of 1935, of a Young Apple Tree of Bearing Age." Memoirs. 201, Cornell University Igr. Exp. Sta., 1936, pp. 1-52.

13. Holsoe, Torkel, Crow'n Development and Basal Area Growth of Red Oak and II'hite Ash. Harvard Forest Papers, Peterstam, Mass., Vol. 1. (1948), pp. 27-33.

14. Holsoe, Torkel, Profitable Tree Forms of Sellowpoplar. W. Va. Agr. Exp. Sta. 13u1l. 341, 1950, p1). 1-23.

17. Jenen, Victor S., and Mac.loney, Harvey J., "Recovery of Birch Filteen Years after Partial cutting." Prosedings, Socioty of American Foresters' Meeting, 1948, pl. $298-392$.

16. Juncker, filcomming, Sefection Thimnings in Denmark. Unpublished M.S., I950.

17. Kianer, P'anl J., "Fiflect of Vartation in Lengeth of bay on Growth and Dor-

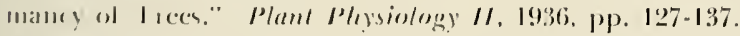

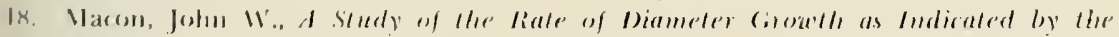

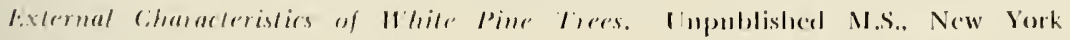
slate cisllege ol fincestry, 1939.

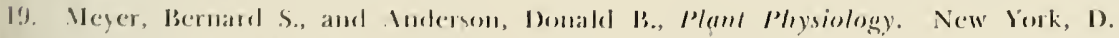
Van Vestrand company, ly46.

20). Muus, 1., "Irorsyndelser mod Skovnaturen sed ror almindelige Skovelrift." Dansk Skonforenings Tidsskrifi, 1921, 121. 1-16.

21. Nowler, Carl Mar., "lioniteringstabeller of bonitcesvise Tilvackstoversigger for

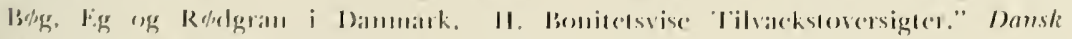

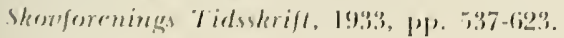


22. M $\phi$ ller, Carl Mar., "Intersuchungen uber Laubmenge, Stoffverlust und Stoffproduktion des Waldes." Det. forstlige Forsogsvaesen i Danmark, Vol. XVII (1945).

23. Nuller, D., Plantefysiologi. Copenhagen, C. Th. Thomsens Bogtrykkeri, 1948.

24. Reineke, L. H., “A Precision Dendiometer." Journal of Forestry, Vol. 30 (October, 1932), p. 692-697.

25. Reventlow, C. D. F., Grundsiitze und Regeln fur den Zweckmässigen Betrieb der Forsten. Copenhagen, Levin and Munksgaard, 1818, and Berlin, Paul Parey, 1934.

26. Stephens, Earl P., and Spurr, Stephen H.. "The Immediate Response of Red Pine to Thinning and Pruning," Proseedings, Society of American Foresters" Meeting (1947), Pp. 353-369.

27. Wadsworth, Frank H., "Value of Small-crowned Ponderosa Pine in Reserve Stands in the Southwest." Journal of Forestry. Vol. 40 (October, 1942), pp. 767-771. 


\section{Appendix}

Basal Area in Square Feet

\begin{tabular}{l|l|l|l|l|l|l|l|l|l|l|l|l|l|l}
\hline \hline D.B.H. & .00 & .01 & .02 & .03 & .04 & .05 & .06 & .07 & .08 & .09
\end{tabular}

$2.00-2.99$ 1NCHES D.B.H

inches

2.0

2.1

2.2

2.3

2.4

2.5

2.6

2.7

2.8

2.9
.0219 .0241

.0264

.0289

.0314

.0341

.0369

.0398

.0428

0459
.0220

.0243

.0266

.0291

.0317

.0344

.0372

.0401

.0431

.0462
.0223

.0245

.0269

.0294

.0319

.0346

.0374

.0404

.0434

.0465
$.0225 \quad .0227$

$.02+7$

.0271

.0296

.0322

.0349

.0377

.0407

.0437

.0468

\section{.0250}

.0274

.0299

.0325

.0352

.0380

.0410

$.0+40$

$.0+71$
$.0229 \quad .0231$

$.0252 \quad .0255$

$.0276 \quad .0279$

.0301

.0327

.0355

.0383

.0413

.0443

.0475
.0304

.0330

.0357

.0386

.0416

.0446

.0478
.0234

.0257

.0281

.0306

.0333

.0360

.0389

.0419

$.0+49$

.0481
.0236

.0284

.0309

.0336

.0363

.0392

.0422

.0452

.0484
.0238

0280

.0312

.0338

.0366

.0395

.0425

.0456

.0488

3.00-3.99 Inches D.B.H.

\begin{tabular}{lllllllllll}
\hline 3.0 & .0491 & .0494 & .0497 & .0501 & .0504 & .0507 & .0511 & .0514 & .0517 & .0521 \\
3.1 & .0524 & .0528 & .0531 & .0534 & .0538 & .0541 & .0545 & .0548 & .0552 & .0555 \\
3.2 & .0559 & .0562 & .0566 & .0569 & .0573 & .0576 & .0580 & .0583 & .0587 & .0590 \\
3.3 & .0594 & .0598 & .0601 & .0605 & .0608 & .0612 & .0616 & .0619 & .0623 & .0627 \\
3.4 & .0631 & .0634 & 0638 & .0642 & .0645 & .0649 & .0653 & .0657 & .0661 & .0664 \\
3.5 & .0668 & .0672 & .0676 & .0680 & .0684 & .0687 & .0691 & .0695 & .0699 & .0703 \\
3.6 & .0707 & .0711 & .0715 & .0719 & .0723 & .0727 & .0731 & .0735 & .0739 & .0743 \\
3.7 & .0747 & .0751 & .0755 & .0759 & .0763 & .0767 & .0771 & .0775 & .0779 & .0783 \\
3.8 & .0785 & .0792 & .0796 & .0800 & .0804 & .0808 & .0813 & .0817 & .0821 & .0825 \\
3.9 & 0830 & .0834 & .0838 & .0842 & .0847 & .0851 & .0855 & .0860 & .0864 & .0868
\end{tabular}

$4.00-4.99$ INCHES D.B.H.

\begin{tabular}{|c|c|c|c|c|c|c|c|c|c|c|}
\hline 4.6) & .0873 & .0877 & .0881 & .0886 & .0890 & .0895 & .0899 & .0904 & .0908 & .0912 \\
\hline 4.1 & .0912 & .1921 & .0926 & .0930 & .0935 & 0939 & .0944 & .0948 & .0953 & .0958 \\
\hline 4.2 & $.096 ; 2$ & $.096 ; 7$ & 0971 & .0976 & .0981 & .0985 & .0990 & .0995 & .0999 & .1004 \\
\hline 4.3 & .10088 & .1013 & .1018 & .1023 & .1027 & .1032 & .1032 & .1642 & .1046 & .1051 \\
\hline 4.4 & . 1656 & $.100 ; 1$ & $.10 \mathrm{gif}$ & .1670 & .1075 & .1080 & .1085 & .1090 & .1095 & .1100 \\
\hline 4.5 & .1364 & 9 & .1114 & .1119 & .1124 & .1129 & .1134 & .1139 & .1144 & .1149 \\
\hline 4.6 & 115.4 & 9159 & .1164 & .1169 & $.117 f$ & .1179 & .1184 & .1130 & .1195 & .1290 \\
\hline 4.7 & $.120 \%$ & .1210 & .1215 & $.12 \% 0$ & .1225 & $.12: 31$ & $.1236 \mathrm{i}$ & .1241 & .1246 & .1251 \\
\hline $1 . x$ & .1257 & .1262 & .1267 & .1272 & .1278 & $.128: 3$ & .1288 & .1294 & .1299 & .1304 \\
\hline 1.9 & .1316 & .1315 & .1320 & .1326 & .1931 & . 1:336; & $.13+2$ & .1347 & .1353 & .1358 \\
\hline
\end{tabular}

5.069 5.99 INCHES 19.13.1I.

\begin{tabular}{|c|c|c|c|c|c|c|c|c|c|c|}
\hline 5.0 & .3364 & .1369 & .1375 & .1380 & .1385 & .1391 & .13997 & .1402 & .1408 & .1413 \\
\hline 5.1 & .3119 & .1421 & .1430 & .1435 & .1 .111 & .1447 & .1452 & .3458 & $.116 ; 1$ & .14699 \\
\hline 5.2 & .3475 & $.1 \times 1$ & $.148 f$ & 1492 & .1468 & $.150 \% 3$ & ) & .1515 & .1521 & .1526 \\
\hline 5.3 & .1532 & $.15: 38$ & .15 .41 & .1550 & .1555 & $.154 ; 1$ & .150177 & $.157: 3$ & .1579 & .1585 \\
\hline 5.4 & .15001 & .3559 & 16,012 & $.1 f_{i}(1) 8$ & .1611 & $.1(; 21)$ & $.16 ; 20$ & $.11,332$ & $.11 i 38$ & .16 .14 \\
\hline 5.5 & $1(i 5)$ & $1 ; ; 5 ;$ & .16 fiz & Jifis & $.16: 74$ & .14801 & Ifixfi & $11 ; 1: 2$ & .1139 .8 & .17011 \\
\hline 5.4 & .1710 & .1717 & .1723 & .1724 & $.17: 35$ & .1741 & .17 .17 & $.175,1$ & $.171 ; 0$ & $.176 \mathrm{ri}$ \\
\hline 5.7 & .1772 & .1778 & .1785 & .1791 & .1767 & $1811: 3$ & .18111 & $.1 \times 16$ & .1822 & $.182 ! 1$ \\
\hline 5.8 & (19:3: & .1811 & $.184 x$ & 1851 & $.18 f i 0$ & $.151 ; 7$ & $.1 \times 7: 3$ & $.187 !$ & .1886 & $.18: 2$ \\
\hline 5.9 & .1x:y! & . $19+1)$ & .1912 & .1918 & .1921 & $.16: 31$ & $.15: 37$ & .1914 & .19150 & .15157 \\
\hline
\end{tabular}


Basal Area in Square Feet

\begin{tabular}{l|l|l|l|l|l|l|l|l|l|l|l}
\hline \hline D.B.H. & .00 & .01 & .02 & .03 & .04 & .05 & .06 & .07 & .08 & .09
\end{tabular}

6. $0-6.99$ INCHES D.B.H.

\begin{tabular}{ccccccccccc}
\hline inches & & & & & & & & & \\
6.0 & .1954 & .1970 & .1977 & .1983 & .1990 & .1296 & .2003 & .2010 & .2016 & .2023 \\
6.1 & .2020 & .2036 & .2043 & .2050 & .2056 & .2063 & .2070 & .2076 & .2083 & .2090 \\
6.2 & .2097 & .2103 & .2110 & .2117 & .2124 & .2131 & .2137 & .2144 & .2151 & .2158 \\
6.3 & .2165 & .2172 & .2179 & .2185 & .2192 & .2199 & .2206 & .2213 & .2220 & .2227 \\
6.4 & .2234 & .2241 & .2248 & .2250 & .2262 & .2269 & .2276 & .2283 & .2290 & .2297 \\
6.5 & .2304 & .2312 & .2319 & .2326 & .2333 & .2740 & .2347 & .2354 & .2362 & .2369 \\
6.6 & .2376 & .2383 & .2390 & .2398 & .2405 & .2412 & .2419 & .2427 & .2434 & .2441 \\
6.7 & .2448 & .2456 & .2463 & .2470 & .2478 & .2485 & .2492 & .2550 & .2507 & .2515 \\
6.8 & .2522 & .2529 & .2537 & .2541 & .2552 & .2559 & .2567 & .2574 & .2582 & .2589 \\
6.9 & .2597 & .2604 & .2612 & .2619 & .2627 & .2635 & .2642 & .2650 & .2657 & .2665 \\
\hline
\end{tabular}

7.00-7.99 INCHES D.B.H.

\begin{tabular}{ccccccccccc}
\hline 7.0 & .2673 & .2680 & .2688 & .2696 & .2703 & .2711 & .2719 & .2726 & .2734 & .2742 \\
7.1 & .2749 & .2757 & .2765 & .2773 & .2781 & .2788 & .2796 & .2804 & .2812 & .2820 \\
7.2 & .2827 & .2835 & .2843 & .2851 & .2859 & .2867 & .2875 & .2883 & .2891 & .2897 \\
7.3 & .2907 & .2915 & .2923 & .2931 & .2939 & .2947 & .2955 & .2963 & .2971 & .2979 \\
7.4 & .2987 & .2995 & .3003 & .3011 & .2019 & .3027 & .3035 & .3044 & .3052 & .3060 \\
7.5 & .3068 & .3076 & .3084 & .3093 & .3101 & .3109 & .3117 & .3126 & .3134 & .3142 \\
7.6 & .3150 & .3159 & .3167 & .3175 & .3184 & .3192 & .3200 & .3209 & .3217 & .3225 \\
7.7 & .3234 & .3242 & .2251 & .3259 & .3268 & .3276 & .3842 &. .293 & .3301 & .3310 \\
7.8 & .3318 & .3327 & .3335 & .3344 & .3352 & .3361 & .3370 & .3378 & .3387 & .3395 \\
7.9 & .3404 & .3413 & .3421 & .3430 & .349 &. .447 & .3456 & .3465 & .3473 & .3482 \\
\hline
\end{tabular}

8.00-8.99 INCHES D B.H.

\begin{tabular}{lllllllllll}
\hline 8.0 & .3491 & .3499 & .3508 & .3517 & .3526 & .3534 & .3543 & .3552 & .3561 & .3570 \\
8.1 & .3579 & .3587 & .3596 & .3605 & .3314 & .3623 & .3632 & .3641 & .3650 & .3658 \\
8.2 & .3667 & .3676 & .3685 & .3694 & .3703 & .3712 & .3721 & .3730 & .3739 & .3748 \\
8.3 & .3757 & .3766 & .3776 & .3785 & .3794 & .3803 & .3712 & .3821 & .3830 & .3839 \\
8.4 & .3849 & .3858 & .3867 & .3876 & .3885 & .3894 & .3904 & .3913 & .3922 & .3931 \\
8.5 & .3941 & .3950 & .3959 & .3968 & .3978 & .3987 & .3997 & .4006 & .4015 & .4025 \\
8.6 & .4034 & .4043 & .4053 & .4062 & .4972 & .4081 & .4050 & .4100 & .4109 & .4119 \\
8.7 & .4128 & .4138 & .4147 & .4157 & .4166 & .4176 & .4185 & .4195 & .4205 & .4214 \\
8.8 & .4224 & .4233 & .4243 & .4253 & .4262 & .6272 & .4282 & .4291 & .4301 & .4311 \\
8.9 & .4320 & .4330 & .4340 & .4349 & .4359 & .4369 & .4379 & .4389 & .4398 & .4408 \\
\hline
\end{tabular}

9.00--9.99 INCHES D.B.H.

\begin{tabular}{lllllllllll}
\hline 9.0 & .4418 & .4428 & .4438 & .4447 & .4457 & .4467 & .4477 & .4487 & .497 & .4507 \\
9.1 & .4517 & .4527 & .4537 & .4546 & .4556 & .4566 & .4576 & .4586 & .4596 & .4606 \\
9.2 & .4616 & .4626 & .4637 & .4647 & .4657 & .4667 & .4677 & .4687 & .4697 & .4707 \\
9.3 & .4717 & .4729 & .4738 & .4748 & .4758 & .4768 & .4778 & .4789 & .4799 & .4809 \\
9.4 & .4819 & .4830 & .4840 & .4850 & .4860 & .4871 & .4881 & .4891 & .4902 & .4912 \\
9.5 & .4922 & .4933 & .4943 & .4954 & .4964 & .4974 & .4985 & .4995 & .5006 & .5016 \\
9.6 & .5027 & .5037 & .5048 & .5058 & .5069 & .5079 & .5090 & .5100 & .5111 & .5121 \\
9.7 & .5132 & .5142 & .5153 & .5164 & .5174 & .5185 & .5196 & .5206 & .5217 & .5228 \\
9.8 & .5238 & .5249 & .5260 & .5270 & .5281 & .5292 & .5303 & .5313 & .5324 & .5335 \\
9.9 & .5346 & .5356 & .5367 & .5378 & .5389 & .5400 & .5411 & .5422 & .5432 & .5443 \\
\hline
\end{tabular}


Basal Area in Square feet

\begin{tabular}{|c|c|c|c|c|c|c|c|c|c|c|}
\hline D.B.H. & .00 & .01 & .02 & .03 & .04 & .05 & .06 & .07 & .08 & .09 \\
\hline & & & \multicolumn{2}{|c|}{$10.00-10.99$} & INCHES & \multicolumn{2}{|c|}{ S D.B.H. } & & & \\
\hline \multicolumn{11}{|l|}{ inches } \\
\hline 10.0 & .5454 & .5466 & .5477 & .5488 & .5499 & .5510 & .5520 & .5531 & .5542 & .5553 \\
\hline 10.1 & .5564 & .5575 & .5586 & .5597 & .5608 & .5620 & .5631 & .5641 & .5652 & .5664 \\
\hline 10.2 & .5675 & .5687 & .5698 & .5708 & .5720 & .5730 & .5742 & .5753 & .5765 & .5776 \\
\hline 10.3 & .5786 & .5799 & .5809 & .5820 & .5831 & .5842 & .5853 & .5866 & .5876 & .5886 \\
\hline 10.4 & .5899 & .5910 & .5921 & .5932 & .5944 & .5956 & .5967 & .5977 & .5990 & .6001 \\
\hline 10.5 & .6013 & .6023 & .6035 & .6047 & .6058 & .6070 & .6082 & .6093 & .6105 & .6117 \\
\hline 10.6 & .6128 & .6140 & .6151 & .6162 & .6174 & .6186 & .6198 & .6209 & .6220 & .6233 \\
\hline 10.7 & .6244 & .6257 & .6270 & .6282 & .6293 & .6305 & .6318 & .6328 & .6340 & .6352 \\
\hline 10.8 & .6362 & .6376 & .6386 & .6398 & .6409 & .6420 & .6433 & .6445 & .6456 & .6468 \\
\hline 10.9 & .6480 & .6492 & .6503 & .6515 & .6528 & .6539 & .6551 & .6562 & .6575 & .6586 \\
\hline
\end{tabular}

11.00-11.99 InCHES D.B.H.

\begin{tabular}{lllllllllll}
\hline 11.0 & .6600 & .6612 & .6626 & .6637 & .6648 & .6660 & .6671 & .6683 & .6695 & .6707 \\
11.1 & .6720 & .6731 & .6743 & .6755 & .6768 & .6780 & .6792 & .6803 & .6816 & .6828 \\
11.2 & .6841 & .6853 & .6866 & .6879 & .6890 & .6901 & .6915 & .6927 & .6940 & .6951 \\
11.3 & .6964 & .6876 & .6990 & .7002 & .7013 & .7026 & .7039 & .7050 & .7062 & .7075 \\
11.4 & .7088 & .7099 & .7111 & .7123 & .7137 & .7149 & .7161 & .7173 & .7187 & .7200 \\
11.5 & .7213 & .7224 & .7236 & .7249 & .7262 & .7275 & .7287 & .7300 & .7313 & .7325 \\
11.6 & .7339 & .7350 & .7363 & .7377 & .7389 & .7401 & .7413 & .7427 & .7439 & .7451 \\
11.7 & .7466 & .7477 & .7490 & .7503 & .7515 & .7528 & .7541 & .7554 & .7567 & .7579 \\
11.8 & .7594 & .7606 & .7619 & .7633 & .7646 & .7659 & .7671 & .7684 & .7692 & .7710 \\
11.9 & .7723 & .7736 & .7749 & .7762 & .7774 & .7789 & .7800 & .7814 & .7828 & .7840 \\
\hline
\end{tabular}

12.00-12.99 INCHES D.B.H.

\begin{tabular}{lllllllllll}
\hline 12.0 & .7854 & .7869 & .7881 & .7894 & .7907 & .7920 & .7933 & .7947 & .7960 & .7972 \\
12.1 & .7985 & .8000 & .8013 & .8027 & .8040 & .8051 & .8067 & .8079 & .8092 & .8105 \\
12.2 & .8118 & .8130 & .8143 & .8157 & .8170 & .8185 & .8199 & .8210 & .8224 & .8237 \\
12.3 & .8252 & .8264 & .8278 & .8292 & .8305 & .8319 & .8331 & .8344 & .8358 & .8370 \\
12.4 & .8386 & .8400 & .8413 & .8427 & .8440 & .8453 & .8469 & .8481 & .8495 & .8509 \\
12.5 & .8522 & .8536 & .8550 & .8563 & .8577 & .8590 & .8603 & .8617 & .8630 & .8644 \\
12.6 & .8659 & .8671 & .8686 & .8700 & .8714 & .8727 & .8740 & .8754 & .8768 & .8781 \\
12.7 & .8797 & .8810 & .8824 & .8838 & .8852 & .8865 & .8880 & .8893 & .8907 & .8920 \\
12.8 & $.893 f ;$ & .8950 & .8963 & .8977 & .8990 & .9005 & .9019 & .9033 & .9048 & .9061 \\
12.9 & $.907 f ;$ & .9090 & .9014 & .9119 & .9132 & .9147 & .9160 & .9173 & .9189 & .9204 \\
\hline
\end{tabular}

13.60-13.99 INCHES D. B.H.

\begin{tabular}{|c|c|c|c|c|c|c|c|c|c|c|}
\hline 13.6 & .9217 & $92: 1$ & .9241 & .9260 & .9274 & .9288 & .9363 & .9317 & .9331 & .9345 \\
\hline 13.1 & $.936 ; 0$ & .9374 & .9388 & $.941) 3$ & .9417 & .9 & $.944 f$ & .9460 & .9474 & .9489 \\
\hline 13.2 & (9:5):3 & .3517 & $.95: 32$ & (954 & $\therefore 561$ & .9575 & $.95 ! 111$ & (n; & .9619 & .9633 \\
\hline 13.3 & $.96,48$ & $.96 ; 1 ; 2$ & .9677 & .96951 & .9706 & .9720 & & & .9764 & .9779 \\
\hline 13.4 & .9793 & .9808 & .9822 & .9837 & .9852 & $.986 ; 6 ;$ & .9881 & .9896 & .9910 & .9925 \\
\hline 13.5 & .9940 & .9555 & $.99 f ; 4$ & .9984 & .95 & 1.0014 & $1.04) 28$ & 1. (1) & 1.0 & 1.0073 \\
\hline 13.6 & 1. $(30) 8$ & $1.1110: 3$ & 1,01117 & $1.01: 32$ & 1.0 & $1.010 ; 2$ & 1.11177 & 1.0192 & 1.0207 & 1.0222 \\
\hline 13.7 & $1.62: 37$ & 1.0252 & $1.1021 ; 7$ & 1.1281 & 1.0296 & 1.4311 & 1.0.:326 & $1.0: 3.11$ & 1.0356 & 1.0372 \\
\hline 13.8 & 1.0 .387 & 1.94012 & 1.9417 & 1.11432 & 1.0 .117 & $1.046 ; 2$ & 1.04477 & 1.0192 & $1.05,177$ & $1.0152: 3$ \\
\hline 13.4 & $1.0: 138$ & 1.65:5:3 & $1.651 ; 8$ & $1.058: 1$ & 1.105988 & $1.06: 14$ & $1.111 ; 2 ! 9$ & $1.111 ; .11$ & 1.065:5! & 1.0675 \\
\hline
\end{tabular}




\section{Basal Area in Square feet}

\begin{tabular}{l|l|l|l|l|l|l|l|l|l|l|l|l}
\hline D.B.H. & .00 & .01 & .02 & .03 & .04 & .05 & .06 & .07 & .08 & .09 \\
\hline
\end{tabular}

14.00-14.99 INCHES D.B.H.

\begin{tabular}{ccccccccccc}
\hline $\begin{array}{c}\text { inches } \\
14.0\end{array}$ & 1.0699 & 1.0705 & 1.0720 & 1.0736 & 1.0751 & 1.0766 & $\mathbf{1 . 0 7 8 2}$ & $\mathbf{1 . 0 7 9 7}$ & 1.0812 & 1.0828 \\
14.1 & 1.0843 & 1.0858 & $\mathbf{1 . 0 8 7 4}$ & 1.0889 & 1.0905 & 1.0920 & 1.0936 & $\mathbf{1 . 0 9 5 1}$ & $\mathbf{1 . 0 9 6 6}$ & 1.0982 \\
14.2 & 1.0997 & 1.1013 & 1.1028 & 1.1044 & 1.1060 & 1.1075 & 1.1091 & 1.1106 & 1.1122 & $\mathbf{1 . 1 1 3 7}$ \\
14.3 & 1.1153 & 1.1168 & 1.1184 & $\mathbf{1 . 1 2 0 0}$ & $\mathbf{1 . 1 2 1 5}$ & 1.1231 & $\mathbf{1 . 1 2 4 7}$ & 1.1262 & 1.1278 & 1.1294 \\
14.4 & 1.1309 & 1.1325 & 1.1341 & 1.1357 & 1.1372 & 1.1388 & 1.1404 & 1.1420 & 1.1435 & 1.1451 \\
14.5 & 1.1467 & 1.1483 & 1.1499 & 1.1515 & 1.1530 & 1.1546 & $\mathbf{1 . 1 5 6 2}$ & 1.1578 & 1.1594 & 1.1610 \\
14.6 & 1.1626 & 1.1642 & 1.1658 & 1.1674 & 1.1690 & 1.1706 & $\mathbf{1 . 1 7 2 2}$ & 1.1737 & 1.1753 & 1.1770 \\
14.7 & 1.1786 & 1.1802 & 1.1818 & 1.1834 & 1.1850 & 1.1866 & 1.1882 & 1.1898 & 1.1914 & 1.1930 \\
14.8 & 1.1946 & 1.1963 & 1.1979 & $\mathbf{1 . 1 9 9 5}$ & $\mathbf{1 . 2 0 1 1}$ & 1.2027 & 1.2043 & 1.2060 & 1.2076 & 1.2092 \\
14.9 & 1.2108 & 1.2125 & 1.2141 & $\mathbf{1 . 2 1 5 7}$ & 1.2174 & 1.2190 & $\mathbf{1 . 2 2 0 6}$ & 1.2222 & 1.2239 & 1.2255 \\
\hline
\end{tabular}

15.00-15.99 INCHES D.B.H.

\begin{tabular}{llllllllllll}
\hline 15.0 & 1.2272 & 1.2288 & 1.2304 & 1.2321 & 1.2331 & 1.2353 & 1.2370 & 1.2386 & 1.2403 & 1.2419 \\
15.1 & 1.2436 & 1.2452 & 1.2469 & 1.2485 & 1.2502 & 1.2518 & 1.2535 & 1.2551 & 1.2568 & 1.2584 \\
15.2 & 1.2601 & 1.2618 & 1.2634 & 1.2651 & 1.2667 & 1.2684 & 1.2701 & 1.2717 & 1.2734 & 1.2751 \\
15.3 & 1.2767 & 1.2784 & 1.2801 & 1.2817 & 1.2834 & 1.2851 & 1.2867 & 1.2884 & 1.2901 & 1.2918 \\
15.4 & 1.2935 & 1.2952 & 1.2968 & 1.2995 & 1.3002 & 1.3019 & 1.3036 & 1.3053 & 1.3069 & 1.3086 \\
15.5 & 1.3103 & 1.3120 & 1.3137 & 1.3154 & 1.3171 & 1.3188 & 1.3205 & 1.3222 & 1.3239 & 1.3256 \\
15.6 & 1.3273 & 1.3290 & 1.3307 & 1.3324 & 1.3341 & 1.3358 & 1.3375 & 1.3392 & 1.3409 & 1.3425 \\
15.7 & 1.3444 & 1.3461 & 1.3478 & 1.3495 & 1.3512 & 1.3529 & 1.3547 & 1.3564 & 1.3581 & 1.3598 \\
15.8 & 1.3615 & 1.3633 & 1.3659 & 1.3667 & 1.3684 & 1.3702 & 1.3719 & 1.3736 & 1.3754 & 1,3771 \\
15.9 & 1.3788 & 1.3806 & 1.3823 & 1.3840 & 1.3858 & 1.3875 & 1.3893 & 1.3910 & 1.3927 & 1.3945 \\
\hline
\end{tabular}

16.00-16.99 INCHES D.B.H.

\begin{tabular}{lllllllllll}
16.0 & 1.3962 & 1.3980 & 1.3997 & 1.4015 & 1.4032 & 1.4050 & 1.4067 & 1.4085 & 1.4102 & 1.4120 \\
16.1 & 1.4137 & 1.4155 & 1.4172 & 1.4190 & 1.4205 & 1.4225 & 1.4243 & 1.4261 & 1.4278 & 1.4296 \\
16.2 & 1.4313 & 1.4331 & 1.4349 & 1.4367 & 1.4384 & 1.4402 & 1.4420 & 1.4437 & 1.4455 & 1.4473 \\
16.3 & 1.4491 & 1.4509 & 1.4526 & 1.4514 & 1.4562 & 1.4580 & 1.4598 & 1.4615 & 1.4633 & 1.4651 \\
16.4 & 1.4669 & 1.4687 & 1.4705 & 1.4723 & 1.4741 & 1.4759 & 1.4777 & 1.4795 & 1.4813 & 1.4832 \\
16.5 & 1.4849 & 1.4867 & 1.4885 & 1.4903 & 1.4921 & 1.4939 & 1.4957 & 1.4975 & 1.4993 & 1.5011 \\
16.6 & 1.5029 & 1.5047 & 1.5065 & 1.5083 & 1.5102 & 1.5120 & 1.5138 & 1.5156 & 1.5174 & 1.5192 \\
16.7 & 1.5211 & 1.5229 & 1.5247 & 1.5265 & 1.5284 & 1.5302 & 1.5320 & 1.5338 & 1.5357 & 1.5377 \\
16.8 & 1.5393 & 1.5412 & 1.5430 & 1.5448 & 1.5467 & 1.5485 & 1.5504 & 1.5522 & 1.5540 & 1.5559 \\
16.9 & 1.5577 & 1.5596 & 1.5614 & 1.5633 & 1.5651 & 1.5669 & 1.5688 & 1.5706 & 1.5725 & 1.5744 \\
\hline
\end{tabular}

17.00--17.99 INCHES D.B.H.

\begin{tabular}{lclllllllll}
\hline 17.0 & 1.5762 & 1.5781 & 1.5800 & 1.5818 & 1.5836 & 1.5855 & 1.5874 & 1.5892 & 1.5911 & 1.5929 \\
17.1 & 1.5948 & 1.5967 & 1.5985 & 1.6094 & 1.6023 & 1.6041 & 1.6060 & 1.6079 & 1.6098 & 1.6116 \\
17.2 & 1.6135 & 1.6154 & 1.6173 & 1.6191 & 1.6210 & 1.6229 & 1.6248 & 1.6267 & 1.6286 & 1.6304 \\
17.3 & 1.6323 & 1.6242 & 1.6361 & 1.6380 & 1.6399 & 1.6418 & 1.6437 & 1.6456 & 1.6475 & 1.6494 \\
17.4 & 1.6513 & 1.6531 & 1.6550 & 1.6570 & 1.6589 & 1.6608 & 1.6627 & 1.6646 & 1.6665 & 1.6689 \\
17.5 & 1.6703 & 1.6722 & 1.6741 & 1.6760 & 1.6780 & 1.6798 & 1.6818 & 1.6837 & 1.6856 & 1.6875 \\
17.6 & 1.6894 & 1.6914 & 1.6933 & 1.6952 & 1.6979 & 1.6990 & 1.7010 & 1.7029 & 1.7048 & 1.7068 \\
17.7 & 1.7087 & 1.7106 & 1.7125 & 1.7145 & 1.7164 & 1.7184 & 1.7203 & 1.7222 & 1.7242 & 1.7261 \\
17.8 & 1.7280 & 1.7300 & 1.7319 & 1.7339 & 1.7358 & 1.7378 & 1.7397 & 1.7417 & 1.7436 & 1.7456 \\
17.9 & 1.7475 & 1.7495 & 1.7514 & 1.7534 & 1.7553 & 1.7573 & 1.7593 & 1.7612 & 1.7631 & 1.7651 \\
\hline
\end{tabular}


Basal Area in Square Feet

\begin{tabular}{l|l|l|l|l|l|l|l|l|l|l}
\hline \hline D.B.H. & .00 & .01 & .02 & .03 & .04 & .05 & .06 & .07 & .08 & .09 \\
\hline
\end{tabular}

18.00-18.99 INCHES D.B.H.

\begin{tabular}{|c|c|c|c|c|c|c|c|c|c|c|}
\hline \multicolumn{11}{|l|}{ inches } \\
\hline 18.0 & 1.7671 & 1.7691 & 1.7710 & 1.7730 & 1.7750 & 1.7769 & 1.7789 & 1.7809 & 1.7828 & 1.7848 \\
\hline 18.1 & 1.7868 & 1.7888 & 1.7908 & 1.7927 & 1.7947 & 1.7967 & 1.7987 & 1.8006 & 1.8026 & 1.8046 \\
\hline 18.2 & 1.8066 & 1.8086 & 1.8106 & 1.8125 & 1.8145 & 1.8165 & 1.8185 & 1.8205 & 1.8225 & 1.8245 \\
\hline 18.3 & 1.8265 & 1.8285 & 1.8305 & 1.8325 & 1.8345 & 1.8365 & 1.8385 & 1.8405 & 1.8425 & 1.8445 \\
\hline 18.4 & 1.8465 & 1.8485 & 1.8505 & 1.8525 & 1.8545 & 1.8566 & 1.8586 & 1.8606 & 1.8626 & 1.8646 \\
\hline 18.5 & 1.8666 & 1.8686 & 1.8707 & 1.8727 & $1.87+7$ & 1.8767 & 1.8788 & 1.8808 & 1.8828 & 1.8848 \\
\hline 18.6 & 1.8869 & 1.8889 & 1.8909 & 1.8930 & 1.8950 & 1.8970 & 1.8991 & 1.9011 & 1.9031 & 1.9052 \\
\hline 18.7 & 1.9072 & 1.9092 & 1.9113 & 1.9133 & 1.9154 & 1.9174 & 1.9195 & 1.9215 & 1.9236 & 1.9256 \\
\hline 18.8 & 1.9277 & 1.9297 & 1.9318 & 1.9338 & 1.9359 & 1.9379 & 1.9400 & 1.9420 & 1.9441 & 1.9462 \\
\hline 18.9 & 1.9482 & 1.9503 & 1.9523 & $1.95+4$ & 1.9565 & 1.9585 & 1.9606 & 1.9627 & 1.9647 & 1.9669 \\
\hline
\end{tabular}

$19.00-19.99$ INches D.B.H.

\begin{tabular}{lllllllllll}
\hline 19.0 & 1.9689 & 1.9710 & 1.9730 & 1.9751 & 1.9772 & 1.9793 & 1.9814 & 1.9833 & 1.9855 & 1.9876 \\
19.1 & 1.9897 & 1.9918 & 1.9938 & 1.9959 & 1.9980 & 2.0001 & 2.0022 & 2.0043 & 2.0064 & 2.0085 \\
19.2 & 2.0106 & 2.0127 & 2.0418 & 2.0169 & 2.0190 & 2.0211 & 2.0232 & 2.0253 & 2.0273 & 2.0295 \\
19.3 & 2.0316 & 2.0337 & 2.0358 & 2.0379 & 2.0400 & 2.0421 & 2.0442 & 2.0463 & 2.0484 & 2.0506 \\
19.4 & 2.0527 & 2.0548 & 2.0569 & 2.0590 & 2.0611 & 2.0633 & 2.0654 & 2.0675 & 2.0696 & 2.0718 \\
19.5 & 2.0739 & 2.0760 & 2.0781 & 2.0803 & 2.0824 & 2.0845 & 2.0867 & 2.0888 & 2.0909 & 2.0931 \\
19.6 & 2.0952 & 2.0973 & 2.0995 & 2.1016 & 2.1038 & 2.1059 & 2.1081 & 2.1102 & 2.1123 & 2.1145 \\
19.7 & 2.1166 & 2.1188 & 2.1209 & 2.1231 & 2.1252 & 2.1274 & 2.1296 & 2.1317 & 2.1339 & 2.1360 \\
19.5 & 2.1382 & 2.1403 & 2.1425 & 2.1447 & 2.1468 & 2.1490 & 2.1512 & 2.1533 & 2.1555 & 2.1577 \\
19.9 & 2.1598 & 2.1620 & 2.1642 & 2.1668 & 2.1685 & 2.1707 & 2.1729 & 2.1751 & 2.1772 & 2.1794 \\
& & & & & & & & & &
\end{tabular}

20.00-20.99 INCHES D.B.H.

$\begin{array}{lllllllllll}20.0 & 2.1816 & 2.1838 & 2.1860 & 2.1882 & 2.1903 & 2.1925 & 2.1947 & 2.1969 & 2.1991 & 2.2013 \\ 20.1 & 2.2035 & 2.2057 & 2.2079 & 2.2101 & 2.2123 & 2.2144 & 2.2166 & 2.2185 & 2.2210 & 2.2232 \\ 20.2 & 2.2255 & 2.2277 & 2.2299 & 2.2321 & 2.2343 & 2.2365 & 2.2387 & 2.2409 & 2.2431 & 2.2453 \\ 20.3 & 2.2175 & 2.2498 & 2.2520 & 2.2542 & 2.2564 & 2.2586 & 2.2608 & 2.2631 & 2.2653 & 2.2675 \\ 21.4 & 2.4977 & 2.5000 & 2.5024 & 2.5047 & 2.5071 & 2.5094 & 2.5117 & 2.5141 & 2.5164 & 2.5188 \\ 20.5 & 2.2920 & 2.2943 & 2.2565 & 2.2988 & 2.3010 & 2.3032 & 2.3055 & 2.3077 & 2.3100 & 2.3122 \\ 20.6 & 2.3145 & 2.3167 & 2.3190 & 2.3212 & 2.3235 & 2.3257 & 2.3280 & 2.3302 & 2.3325 & 2.3347 \\ 20.7 & 2.3370 & 2.3392 & 2.3415 & 2.3438 & 2.3460 & 2.3483 & 2.3506 & 2.3528 & 2.3551 & 2.3573 \\ 20.8 & 2.3596 & 2.3619 & 2.3642 & 2.3664 & 2.3697 & 2.3709 & 2.3733 & 2.3755 & 2.3778 & 2.3801 \\ 20.9 & 2.3824 & 2.386 ; & 2.3869 & 2.3899 & 2.3915 & 2.3938 & 2.3961 & 2.3983 & 2.4006 & 2.4029\end{array}$

$21.00-21.99$ 1NCHES D.13.H.

\begin{tabular}{|c|c|c|c|c|c|c|c|c|c|c|}
\hline 21.6 & 2.41152 & $2.46,75$ & 2.4068 & 2.4121 & 2.1144 & 2.4167 & $2 .+190$ & 2.1213 & 2.4236 & 2.1259 \\
\hline 211 & 2.4282 & 2.1305 & 2.132 .8 & 2.1351 & $2.437 t$ & 2.4397 & 2.4120 & $2.4+43$ & $2.4 \pm 66$ & 13 \\
\hline 21.2 & 2.4512 & $2.453 \%$ & 2.4559 & 2.4582 & $2 .+605$ & 2.4628 & 2.4651 & $2.46,75$ & 2.1698 & 2.175 \\
\hline 21.3 & $2.47+4$ & $2.47 i ; 7$ & 2.4791 & 2.1814 & 2.4837 & $2.486 ; 1$ & 2.4884 & 2.1907 & 2.4930 & $2.1 !$ \\
\hline 21.4 & 2.4877 & $2.50(0) 011$ & $2.51,24$ & $2.51) 47$ & 2.50171 & 2.50944 & 2.5117 & 2.5111 & 2.516 .4 & \\
\hline 21.5 & 2.5211 & 2.5235 & 2.5258 & 2.5 .282 & 2.53015 & 2.5328 & 2.5352 & 2.5376 & 2.53399 & in \\
\hline 21.1 & 2.5146 & 2.54711 & 2.5.45:3 & 2.5517 & 2.55111 & $2.5556 ; 4$ & 2.5588 & $2.56 ; 11$ & 2.569355 & $\therefore$ \\
\hline 21.7 & 2.51582 & $2.57(16)$ & $2.57: 311$ & 2.5753 & 2.5777 & 2.58111 & 2.5825 & 2.5848 & 2.5877 & .58 \\
\hline 21.8 & $2.5 \div 120$ & $2.5: 14: 3$ & 2.519677 & $2.5(95) 1$ & 2.151115 & 2.600:3:1 & $2.6061 ; 2$ & $2.6 ; 0 \times 1 ;$ & 2.6110 & $2.61:$ \\
\hline 21.9 & $2.4 ; 58$ & $2.6 ; 182$ & $2.6 ; 2616 ;$ & $2.112: 311$ & $2.6: 271$ & $2.6,278$ & 2.19301 & $2.13: 325$ & $2.1: 3.141$ & $2.6:$ \\
\hline
\end{tabular}


Basal Area in Square feet

\begin{tabular}{l|l|l|l|l|l|l|l|l|l|l|l|l|}
\hline D.B.H. & .00 & .01 & .02 & .03 & .04 & .05 & .06 & .07 & .08 & .09
\end{tabular}

$22.00-22.99$ Ixches D.B.H.

\begin{tabular}{cllllllllll}
\hline inches & & & & & & & & & & \\
22.0 & 2.6397 & 2.6421 & 2.6445 & 2.6469 & 2.6493 & 2.6519 & 2.6542 & 2.6566 & 2.6590 & 2.6614 \\
22.1 & 2.6638 & 2.6662 & 2.6686 & 2.6710 & 2.6734 & 2.6759 & 2.6783 & 2.6807 & 2.6831 & 2.6855 \\
22.2 & 2.6879 & 2.6904 & 2.6928 & 2.6952 & 2.6976 & 2.7001 & 2.7025 & 2.7049 & 2.7074 & 2.7098 \\
22.3 & 2.7122 & 2.7147 & 2.7171 & 2.7195 & 2.7220 & 2.7244 & 2.7268 & 2.7293 & 2.7317 & 2.7342 \\
22.4 & 2.7366 & 2.7383 & 2.7415 & 2.7439 & 2.7464 & 2.7488 & 2.7513 & 2.7537 & 2.7562 & 2.7586 \\
22.5 & 2.7611 & 2.7635 & 2.7660 & 2.7685 & 2.7709 & 2.7734 & 2.7758 & 2.7783 & 2.7807 & 2.7832 \\
22.6 & 2.7857 & 2.7881 & 2.7906 & 2.7931 & 2.7856 & 2.7980 & 2.8005 & 2.8030 & 2.8054 & 2.8079 \\
22.7 & 2.8104 & 2.8129 & 2.8153 & 2.8178 & 2.8203 & 2.8228 & 2.8253 & 2.8278 & 2.8302 & 2.8327 \\
22.8 & 2.8352 & 2.8377 & 2.8402 & 2.8427 & 2.8452 & 2.8477 & 2.8502 & 2.8526 & 2.8551 & 2.8576 \\
22.9 & 2.8601 & 2.8626 & 2.8651 & 2.8676 & 2.8701 & 2.8726 & 2.8751 & 2.8776 & 2.8801 & 2.8827 \\
\hline
\end{tabular}

23.00-23.99 INCHES D.B.H.

\begin{tabular}{lllllllllll}
\hline 23.0 & 2.8852 & 2.8877 & 2.8902 & 2.8927 & 2.8952 & 2.8977 & 2.9002 & 2.9028 & 2.9053 & 2.9078 \\
23.1 & 2.9103 & 2.9128 & 2.9153 & 2.9179 & 2.9204 & 2.9229 & 2.9254 & 2.9280 & 2.9305 & 2.9330 \\
23.2 & 2.9356 & 2.9381 & 2.9406 & 2.9432 & 2.9457 & 2.9482 & 2.9508 & 2.9533 & 2.9558 & 2.9584 \\
23.3 & 2.9609 & 2.9635 & 2.9660 & 2.9686 & 2.9711 & 2.9736 & 2.9762 & 2.9787 & 2.9813 & 2.9838 \\
23.4 & 2.9864 & 2.9889 & 2.9915 & 2.9941 & 2.9966 & 2.9992 & 3.0017 & 3.0043 & 3.0069 & 3.0094 \\
23.5 & 3.0120 & 3.0145 & 3.0171 & 3.0197 & 3.0222 & 3.0248 & 3.0274 & 3.0299 & 3.0325 & 3.0351 \\
23.6 & 3.0377 & 3.0402 & 3.0428 & 3.0454 & 3.0480 & 3.0505 & 3.0531 & 3.0557 & 3.0583 & 3.0609 \\
23.7 & 3.0635 & 3.0660 & 3.0686 & 3.0712 & 3.0738 & 3.0764 & 3.0790 & 3.0816 & 3.0842 & 3.0868 \\
23.8 & 3.0894 & 3.0920 & 3.0946 & 3.0972 & 3.0998 & 3.1024 & 3.1050 & 3.1076 & 3.1102 & 3.1128 \\
23.9 & 3.1154 & 3.1180 & 3.1206 & 3.1232 & 3.1258 & 3.1284 & 3.1310 & 3.1337 & 3.1363 & 3.1389 \\
\hline
\end{tabular}

24.00-24.99 INCHES D.B.H.

\begin{tabular}{lllllllllll}
\hline 24.0 & 3.1415 & 3.1441 & 3.1467 & 3.1494 & 3.1520 & 3.1546 & 3.1572 & 3.1599 & 3.1625 & 3.1651 \\
24.1 & 3.1677 & 3.1704 & 3.1730 & 3.1756 & 3.1783 & 3.1809 & 3.1835 & 3.1862 & 3.1888 & 3.1914 \\
24.2 & 3.1941 & 3.1967 & 3.1994 & 3.2020 & 3.2047 & 3.2072 & 3.2099 & 3.2126 & 3.2152 & 3.2179 \\
24.3 & 3.2205 & 3.2233 & 3.2258 & 3.2285 & 3.2311 & 3.2338 & 3.2365 & 3.2395 & 3.2418 & 3.2444 \\
24.4 & 3.2471 & 3.2498 & 3.2524 & 3.2551 & 3.2577 & 3.2604 & 3.2631 & 3.2657 & 3.2684 & 3.2711 \\
24.5 & 3.2738 & 3.2764 & 3.2791 & 3.2818 & 3.2839 & 3.2871 & 3.2898 & 3.2925 & 3.2952 & 3.2979 \\
24.6 & 3.3005 & 3.3032 & 3.3059 & 3.3086 & 3.3113 & 3.3140 & 3.3167 & 3.3194 & 3.3220 & 3.3247 \\
24.7 & 3.3274 & 3.3301 & 3.3328 & 3.3355 & 3.3382 & 3.3409 & 3.3436 & 3.3463 & 3.3490 & 3.3517 \\
24.8 & 3.3544 & 3.3571 & 3.3598 & 3.3625 & 3.3653 & 3.3680 & 3.3707 & 3.3734 & 3.3761 & 3.3788 \\
24.9 & 3.3815 & 3.3843 & 3.3869 & 3.3897 & 3.3924 & 3.3951 & 3.3978 & 3.4006 & 3.4033 & 3.4060 \\
\hline
\end{tabular}

25.00-25.99 INCHES D.B.H.

\begin{tabular}{lllllllllll}
\hline 25.0 & 3.4087 & 3.4105 & 3.4142 & 3.4169 & 3.4192 & 3.4224 & 3.4251 & 3.4279 & 3.4306 & 3.4333 \\
25.1 & 3.4361 & 3.4388 & 3.4416 & 3.4443 & 3.4470 & 3.4498 & 3.4525 & 3.4553 & 3.4580 & 3.4608 \\
25.2 & 3.4635 & 3.4663 & 3.4690 & 3.4718 & 3.4745 & 3.4773 & 3.4800 & 3.4828 & 3.4855 & 3.4883 \\
25.3 & 3.4911 & 3.4938 & 3.4966 & 3.4993 & 3.5021 & 3.5049 & 3.5076 & 3.5104 & 3.5132 & 3.5159 \\
25.4 & 3.5187 & 3.5215 & 3.5242 & 3.5270 & 3.5298 & 3.5326 & 3.5353 & 3.5381 & 3.5409 & 3.5437 \\
25.5 & 3.5465 & 3.5492 & 3.5520 & 3.5548 & 3.5576 & 3.5604 & 3.5632 & 3.5660 & 3.5687 & 3.5715 \\
25.6 & 3.5743 & 3.5771 & 3.5799 & 3.5827 & 3.5855 & 3.5883 & 3.5911 & 3.5939 & 3.5967 & 3.5995 \\
25.7 & 3.6023 & 3.6051 & 3.6079 & 3.6107 & 3.6135 & 3.6163 & 3.6192 & 3.6220 & 3.6248 & 3.6276 \\
25.8 & 3.6304 & 3.6332 & 3.6360 & 3.6388 & 3.6417 & 3.6444 & 3.6473 & 3.6501 & 3.6529 & 3.6558 \\
25.9 & 3.6586 & 3.6614 & 3.6642 & 3.6671 & 3.6699 & 3.6727 & 3.6756 & 3.6784 & 3.6812 & 3.6841 \\
\hline
\end{tabular}


Basal Area in Square Feet

\begin{tabular}{|c|c|c|c|c|c|c|c|c|c|c|}
\hline D.B.H. & .00 & .01 & .02 & .03 & .04 & .05 & .06 & .07 & .08 & .09 \\
\hline \multicolumn{11}{|c|}{$26.00-26.99$ INCHFS D.B.H. } \\
\hline \multicolumn{11}{|l|}{ inches } \\
\hline 26.0 & 3.6869 & 3.6897 & 3.6926 & 3.6954 & 3.6983 & 3.7011 & 3.7039 & 3.7068 & 3.7096 & 3.7125 \\
\hline 26.1 & 3.7153 & 3.7182 & 3.7210 & 3.7239 & 3.7267 & 3.7296 & 3.7324 & 3.7353 & 3.7381 & 3.7410 \\
\hline 26.2 & 3.7438 & 3.7467 & 3.7496 & 3.7524 & 3.7553 & 3.7581 & 3.7610 & 3.7639 & 3.7668 & 3.7696 \\
\hline 26.3 & 3.7725 & 3.7753 & 3.7782 & 3.7811 & 3.7840 & 3.7868 & 3.7897 & 3.7926 & 3.7955 & 3.7983 \\
\hline 26.4 & 3.8012 & $3.80+1$ & 3.8070 & 3.8099 & 3.9127 & 3.8156 & 3.8185 & 3.8214 & $3.82+3$ & 3.8272 \\
\hline 26.5 & 3.8301 & 3.8330 & 3.8359 & 3.8387 & 3.8416 & 3.8445 & 3.8474 & 3.8503 & 3.8532 & 3.8561 \\
\hline 26.6 & 3.8590 & 3.8619 & 3.8648 & 3.8677 & 3.8706 & 3.8736 & 3.8765 & 3.8794 & 3.8823 & 3.8852 \\
\hline 26.7 & 3.8881 & 3.8910 & 3.8939 & 3.8968 & 3.8998 & 3.9027 & 3.9056 & 3.9085 & 3.9114 & 3.9144 \\
\hline 26.8 & 3.9173 & 3.9202 & 3.9231 & 3.9261 & 3.9290 & 3.9319 & 3.9348 & 3.9378 & 3.9407 & 3.9436 \\
\hline 26.9 & 3.9466 & 3.9495 & 3.9524 & 3.9554 & 3.9583 & 3.9613 & 3.9642 & 3.9671 & 3.9701 & 3.9730 \\
\hline
\end{tabular}

$27.00-27.99$ INCHES D.B.H.

\begin{tabular}{lllllllllll}
\hline 27.0 & 3.9760 & 3.9789 & 3.9819 & 3.9848 & 3.9878 & 3.9907 & 3.9937 & 3.9966 & 3.9996 & 4.0025 \\
27.1 & 4.0055 & 4.0084 & 4.0114 & 4.0143 & 4.0173 & 4.0203 & 4.0232 & 4.0262 & 4.0292 & 4.0321 \\
27.2 & 4.0351 & 4.0381 & $\mathbf{4 . 0 4 1 0}$ & 4.0440 & 4.0470 & 4.0499 & 4.0529 & 4.0559 & 4.0589 & 4.0618 \\
27.3 & 4.0648 & 4,0678 & 4.0708 & 4.0738 & 4.0767 & 4.0797 & 4.0827 & 4.0857 & 4.0887 & 4.0917 \\
27.4 & 4.0946 & 4.0976 & 4.1006 & 4.1036 & 4.1066 & 4.1096 & 4.1126 & 4.1156 & 4.1186 & 4.1216 \\
27.5 & 4.1246 & 4.1276 & 4.1306 & 4.1336 & 4.1366 & 4.1396 & 4.1426 & 4.1456 & 4.1486 & 4.1516 \\
27.6 & 4.1546 & 4.1576 & 4.1607 & 4.1637 & 4.1667 & 4.1697 & 4.1727 & 4.1757 & 4.1788 & 4.1818 \\
27.7 & 4.1848 & 4.1878 & 4.1908 & 4.1939 & 4.1969 & 4.1999 & 4.2030 & 4.2060 & 4.2090 & 4.2120 \\
27.8 & 4.2151 & 4.2181 & 4.2211 & 4.2242 & 4.2272 & 4.2302 & 4.2333 & 4.2363 & 4.2394 & 4.2424 \\
27.9 & 4.2464 & 4.2485 & 4.2515 & 4.2546 & 4.2576 & 4.2607 & 4.2637 & 4.2668 & 4.2698 & 4.2729 \\
\hline
\end{tabular}


